\title{
NEW DRY GRASSLAND ASSOCIATIONS FROM THE AUSONI-AURUNCI MOUNTAINS (CENTRAL ITALY) - SYNTAXONOMICAL UPDATING AND DISCUSSION ON THE HIGHER RANK SYNTAXA
}

\author{
Romeo DI PIETRO*
}

\begin{abstract}
A phytosociological study on the most extensive dry grassland communities of the coastal limestone massif of the Ausoni-Aurunci mountains (southern Latium, central Italy) is here presented. Violo pseudogracilis-Koelerietum splendentis ass. nova is restricted to the montane belt of the Aurunci mountains where it is dynamically related to the mesophilous Ostrya carpinifolia or Fagus sylvatica woodlands. Helichryso italici-Brometum erecti ass. nova is found within the upper hilly and submontane belt of both the Ausoni mountains (typical aspect) and the Aurunci mountains (subassociation saturejetosum montanae), where it is dynamically related with termophilous Ostrya carpinifolia woods and mesophilous Quercus ilex woods. Helichryso-Brometum is differentiated from VioloKoelerietum in that it has a higher incidence of the steno-Mediterranean therophytic component. As far as the higher rank syntaxa are concerned, in this study the following changes were made in accordance with the rules of ICPN: the name Phleo ambigui-Bromion erecti Biondi et al. 1995 was considered invalid due to the invalidity of its nomenclatural type Asperulo purpureae-Brometum erecti. In contrast, the validity of the old name Cytiso spinescentisBromion erecti Bonin 1978 was demonstrated and its nomenclatural type, Lavandulo-Asphodelinetum luteae Bonin 1978, was lectotypified. Thus Cytiso spinescenti-Bromion erecti Bonin 1978 henceforth substitutes Phleo ambiguiBromion erecti (nom. inval.) as the syntaxonomical reference for the endemic alliance of the hilly and montane limestone dry grasslands of the central and southern Apennines. Cytiso-Bromion is here divided into two suballiances: Sideritidenion italicae Biondi et al. 1995, Phleo ambigui-Bromenion erecti Biondi et al. ex Di Pietro suball. nov. Cytiso-Bromion belong to the new suborder Festuco circummediterraneae-Seslerienalia nitidae (Ubaldi 2003) stat. nov. and to the order Artemisio albae-Brometalia erecti Ubaldi ex Mucina \& Dengler 2009. New and updated packages of characteristic and differential species for both Cytiso spinescenti-Bromion erecti and its related suballiances are proposed. Furthermore the validity of the name Astragaletum calabrici Giacomini \& Gentile ex Bonin 1978, was proved and the association lectotypified. This association, which was previously included in Cytiso-Bromion erecti, is moved into Koelerio brutiae-Astragalion calabrici. Finally some interesting coenological and syndynamical similarities with Scorzonero-Chrysopogonetalia western Dalmatia submediterranean dry pastures are discussed. Key words: Apennines, chorology, ICPN, nomenclatural types, phytosociology, syntaxonomy.
\end{abstract}

\begin{abstract}
Izvleček
Fitocenološka raziskava predstavlja najbolj razširjene združbe suhih travišč obalnega masiva pogorja AusoniAurunci (južni Lazio, osrednja Italija). Violo pseudogracilis-Koelerietum splendentis ass. nova je razširjena samo v montanskem pasu gorovja Aurunci, kjer je v dinamični povezavi z mezofilnimi gozdovi črnega gabra (Ostrya carpinifolia) in gozdovi bukve (Fagus sylvatica). Helichryso italici-Brometum erecti ass. nova najdemo na zgornjem delu gričevnatega in v podgorskem pasu tako gorovja Ausoni (tipični aspekt) in gorovja Aurunci (subasociacija saturejetosum montanae), kjer se dinamično navezuje na termofilne gozdove črnega gabra in mezofilne gozdove črničevja (Quercus ilex). Večji delež stenomediteranskega terofitskega elementa razlikuje asociacijo HelichrysoBrometum od asociacije Violo-Koelerietum. Glede višjih sintaksonov, smo v tem prispevku naredili naslednje spremembe v skladu z mednarodnim kodeksom fitocenološke nomenklature; poimenovanje Phleo ambugui-Bromion erecti Biondi et al. 1995 obravnavamo kot neveljavno, ker je neveljaven nomenklatorni tip Asperulo purpureaeBrometum erecti. Za razliko pa je prikazana veljavnost starega poimenovanja Cytiso spinescentis-Bromion erecti Bo-
\end{abstract}

\footnotetext{
* Department DATA, Sapienza University of Rome, Via Flaminia 72, I-00196 Rome, E-mail: romeo.dipietro@uniroma1.it
} 
nin 1978, izbran je tudi nomenklaturni tip in sicer Lavandulo-Asphodeletum luteae Bonin 1978 kot lektotip. Tako poimenovanje Cytiso spinescentis-Bromion erecti Bonin 1979 od sedaj zamenjuje Phleo ambigui-Bromion erecti (nom. inval.) kot sintaksonomska oznaka za endemično zvezo suhih travišč na apnencu, ki se pojavlja v gričevnatem in gorskem pasu v osrednjih in južnih Apeninih. Zveza Cytiso-Bromion je razdeljena v dve podzvezi: Sideritidenion italicae Biondi et al. 1995 in Phleo ambigui-Bromenion erecti Biondi et al. ex Di Pietro suball. nova. Zvezo Cytiso-Bromenion uvrščamo v nov podred Festuco-Seslerienalia nitidae Ubaldi 2003 statt. nov. in red Artemisio albaeBrometalia erecti Ubaldi ex Mucina \& Dengler 2009. Nove in posodobljene so tudi skupine značilnih in razlikovalnih vrst tako za zvezo Cytiso spinescenti-Bromion erecti in podrejeni podzvezi. Poleg tega pa se je poimenovanje asociacije Astragaletum calabrici Giacomini \& Gentile ex Bonin 1978 izkazalo za pravilno in je bila asociacija lektotipificirana. Ta asociacija, ki je bila vključena v zvezo Cytiso-Bromion erecti, je bila premeščena v Koelerio brutiae-Astragalion calabrici. Na koncu smo obravnavali nekateri zanimive cenološke in sindinamske podobnosti z redom Scorzonero-Chrysopogonetalia, kamor uvrščamo suhe submediteranske pašnike v zahodni Dalmaciji.

Ključne besede: Apenini, horologija, ICPN, nomenklaturni tipi, fitocenologija, sintaksonomija.

\section{INTRODUCTION}

Owing to their floristic richness and coenological diversity, the Central Apennines are globally recognized as one of the most important European centres of plant speciation and floristic richness (Blasi et al. 2005; 2010). A significant part of this biodiversity is concentrated in grassland environments, and in particular in the secondary FestucoBrometea dry montane grasslands, where several endemic and rare plant species occur. Indeed the Italian Interpretation Manual of the 92/43/EEC Directive Habitats (Biondi et al. 2009) enlarged the ecological space of Habitat $6210^{*}$ precisely to maintain such an important coenological and floristic heritage. From a phytosociological viewpoint the first studies on central Apennines dry grasslands were carried out at the end of the 1960s (Bruno \& Covarelli 1968) and were significantly intensified in the period straddling 1970 and 1990 (Avena \& Bruno 1975; Hruska-Dell'Uomo 1976; Ballelli et al. 1977; Bonin 1978; Avena \& Blasi 1979; 1980; Biondi \& Ballelli 1981; 1982; Ballelli \& Biondi 1982; Biondi \& Blasi 1982; Hruska 1982; Biondi et al., 1986; Biondi 1988; Biondi et al. 1988; Frattaroli 1988; Blasi et al. 1990). These studies led to the proposal of the endemic alliance Crepido lacerae-Phleion ambigui, (subsequently changed to Phleo ambigui-Bromion erecti in Biondi et al. 1995; 2005) as the Apennine vicariant of the European Xerobromion. During the 1990s and the first decade of the 2000s, several other studies focused on the dry grasslands of central Italy and several new associations were proposed (Biondi et al. 1992; Castelli 1995; Blasi et al. 1998; Venanzoni \& Gigante 1999; Castelli et al. 2001; Allegrezza 2003; Biondi et al. 2004; Ciaschetti et al. 2006; Catorci et al. 2007). Most of these studies dealt with geo- graphical areas located in the core of the central Apennines or on the Adriatic side of the Italian Peninsula. In contrast, very few (Lucchese \& Pignatti 1990; Lucchese et al. 1995; Scoppola \& Pelosi 1995; Di Pietro \& Blasi 2002; Angiolini et al. 2003) phytosociological studies have ever been carried out on the perennial dry grasslands occurring in the coastal mountainous chains of the western side of the Italian Peninsula, which is separated from the true Apennines by large alluvial valleys furrowed by major rivers such as the Tiber, Sacco, Liri and Garigliano. This geographical discontinuity from the rest of the Apennines, together with the vicinity of the coast, are factors which have led to the development on these coastal massifs of a vegetation characterised by a greater influence of the Mediterranean floristic component in comparison to the vegetation found both in the core of the Apennines and on the Adriatic side of the peninsula. The present paper focuses on the most extensive Festuco-Brometea dry grasslands of the Ausoni-Aurunci range, for which neither a phytosociological study nor a syntaxonomical analysis had ever previously been carried out. In addition a coenological, syntaxonomical and nomenclatural analysis of the most important syntaxa related to the dry grasslands of the AusoniAurunci mountains is also performed here.

\section{STUDY AREA}

The Ausoni-Aurunci Mountains are a limestone mountain range of southern Lazio, in central Italy (Figure 1) which are bounded northwestward by the Lepini mountains, northward by the Liri river, southeastward by the Garigliano river and southward by the Tyrrhenian sea. Altitudes 


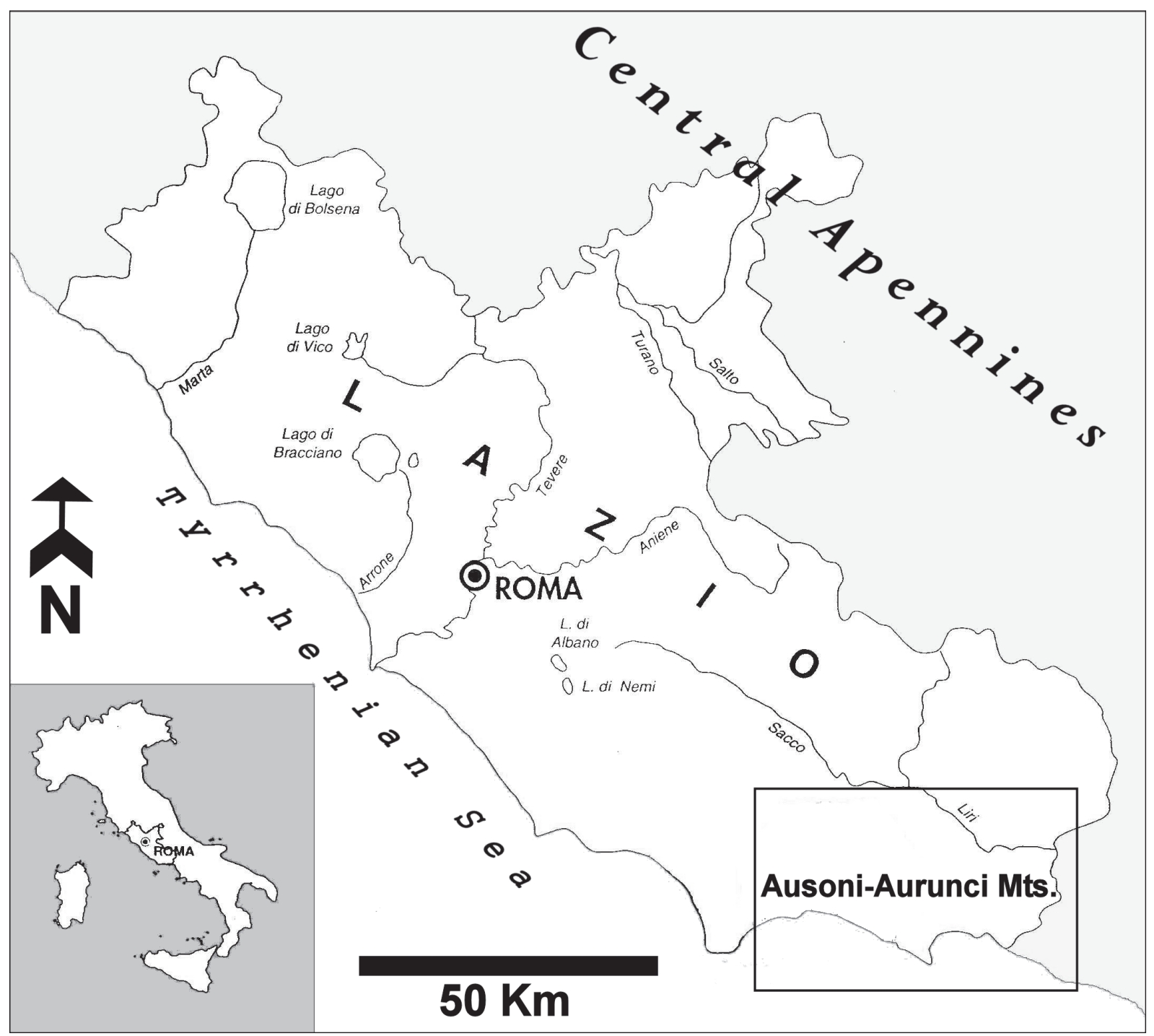

Figure 1: Ausoni-Aurunci Mts. study area.

Slika 1: Raziskovano območje v hribovju Ausoni-Aurunci.

vary from 0 (Promontory of Gaeta and Sperlonga) to the 1,533 $\mathrm{m}$ a.s.l. of Mount Petrella. Main peaks include also Mount Redentore (1,252 m), Mount Sant'Angelo (1,402 m) and Mount Ruazzo (1,322 m). The Ausoni-Aurunci mountains mainly consist of friable cretaceous and paleocenic limestone (Figure 2) but the degree of faulting and cracking is so high that the mountains retain no rainfall. The stream beds are dry except for vernal pools. From a bioclimatic point of view the Aurunci mountains are located at the boundary between the Mediterranean and the Temperate regions (Figure 3). Mean annual rainfalls are quite abundant in the whole area, ranging from about $1000 \mathrm{~mm}$ at sea level to over $1600 \mathrm{~mm}$ in the mon- tane belt (Blasi 2006). Mean annual temperature ranges between $18{ }^{\circ} \mathrm{C}$ and $10^{\circ} \mathrm{C}$ moving from the coastal areas to the top of the mountains. The altitudinal zonation of the potential vegetation provides primary Mediterranean maquis in the coastal promontory Quercus ilex woods on the south facing slopes of the hilly and submontane belts. Quercus pubescens woodlands prevail on the footslopes whereas Quercus cerris woodlands are located at the bottom of the intra-montane karst plateaus where a higher content of clay occurs. The north facing slopes are dominated by Carpinus orientalis woods (hilly belt) and Ostrya carpinifolia woods (submontane-montane belt). Fagus sylvatica woods characterise the upper part of the inner part of the range. 


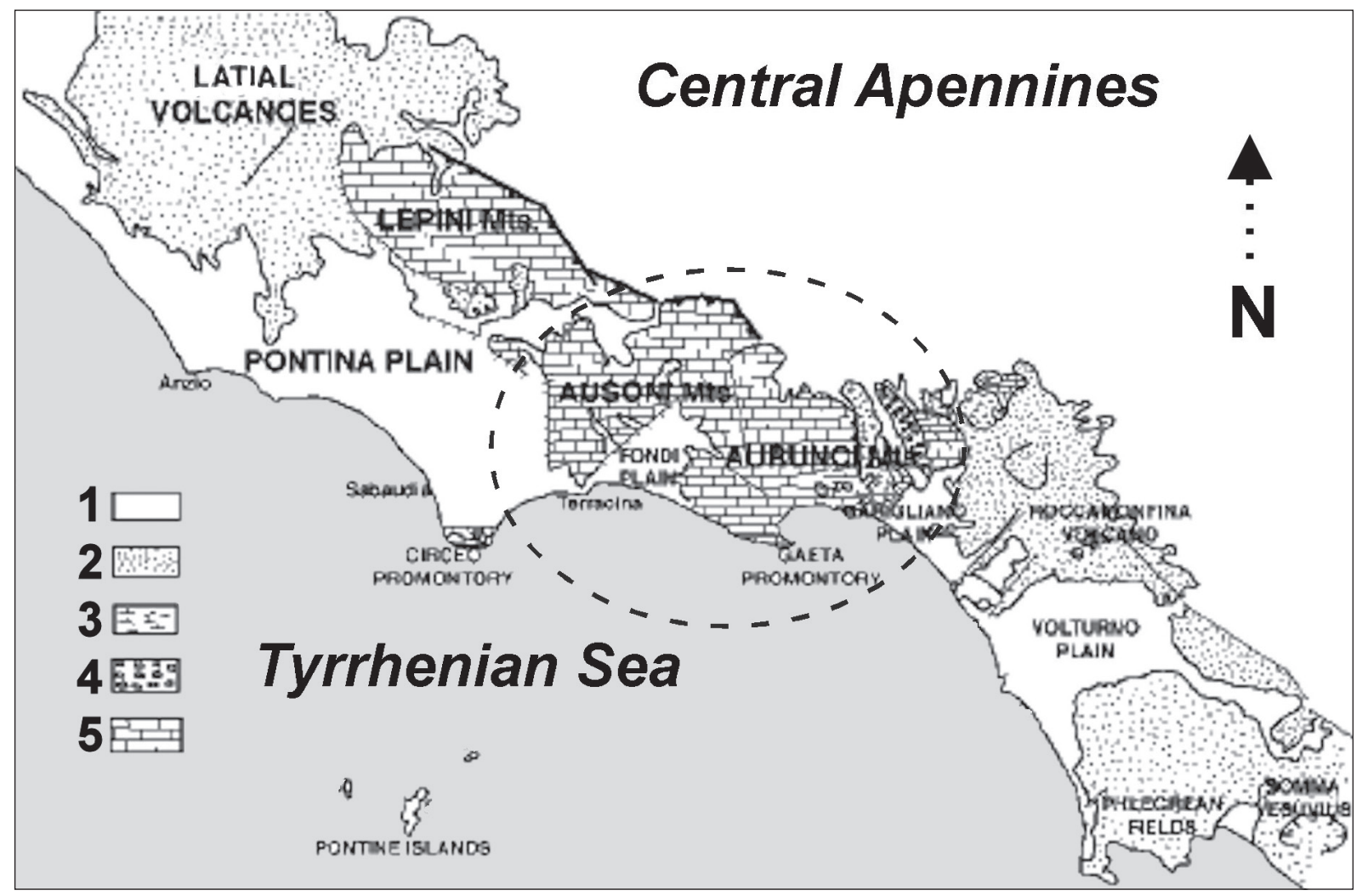

Figure 2: Geological features of tyrrhenian district of southern Latium and adjacent Campania region. 1: Continental and marine deposits (Holocene, late Pleistocene); 2: Volcanic deposits (Quaternary); 3: Arenaceous-clayey turbidites (TortonianMessinian); 4) Shallow water organogenic Limestone (Langhian-Serravallian); 5: shallow water limestone (Jurassic-Creataceous-Paleocenic).

Slika 2: Geološke lastnosti tirenskega distrikta južnega dela regije Lazio in sosednje Campanije. 1: celinske in morke usedline (Holocen, pozni Pleistocen); 2: vulkanske usedline (Kvartar); 3: arenitno-glinene turbiditne usedline (Tortonian-Messinian); 4) plitvi vodni organogeni apnenec (Langhian-Serravallian); 5: plitvi vodni apnenec (Jura-Kreda-Paleocen).

\section{MATERIAL AND METHODS}

In all, 49 phytosociological relevés were made following the phytosociological methods of the $\mathrm{Zu}$ rich-Montpellier school (Braun-Blanquet 1964). The cluster analysis was performed by means of the software SYNTAX 2000 (Podani 2001), using UPGMA and a similarity ratio coefficient on the phytosociological data converted according to the ordinal scale proposed by van der Maarel (1979).

The ordination diagram was obtained through PCA procedure. The Life form and chorological spectra (based on presence, frequency and specific cover index) were calculated for each community type and reference was made to Pignatti et al. (2005). Following the chorotype and the life form names, a sequence of three values (\%) appears in the tables (Figures 8, 9, 10), corresponding, respectively, to the simple presence (Pres.), the frequency (Frq.) and the specific cover index (Cov.) of a given chorotype/life form in each phytosociological table (Braun-Blanquet 1964). The "specific cover index" was obtained by summing up each species' cover-abundance central values (e.g. $5=87.5 ; 4=62.5 \ldots$ ) and multiplying this sum by the ratio 100 /numbers of relevés. UPGMA and similarity ratio coefficient were also used for the cluster analysis of the synoptic table (Table 3), which includes all the Peninsular Italy dry grassland associations exhibiting a high degree of floristic and coenological similarity to the Ausoni-Aurunci communities.

The plants collected in the field were determined using Tutin et al. (1968-1980; 1993) and Pignatti (1982), while species nomenclature was updated according to Conti et al. (2005). The rank of subspecies was specified only when it did not coincide with that of the nominal subspe- 


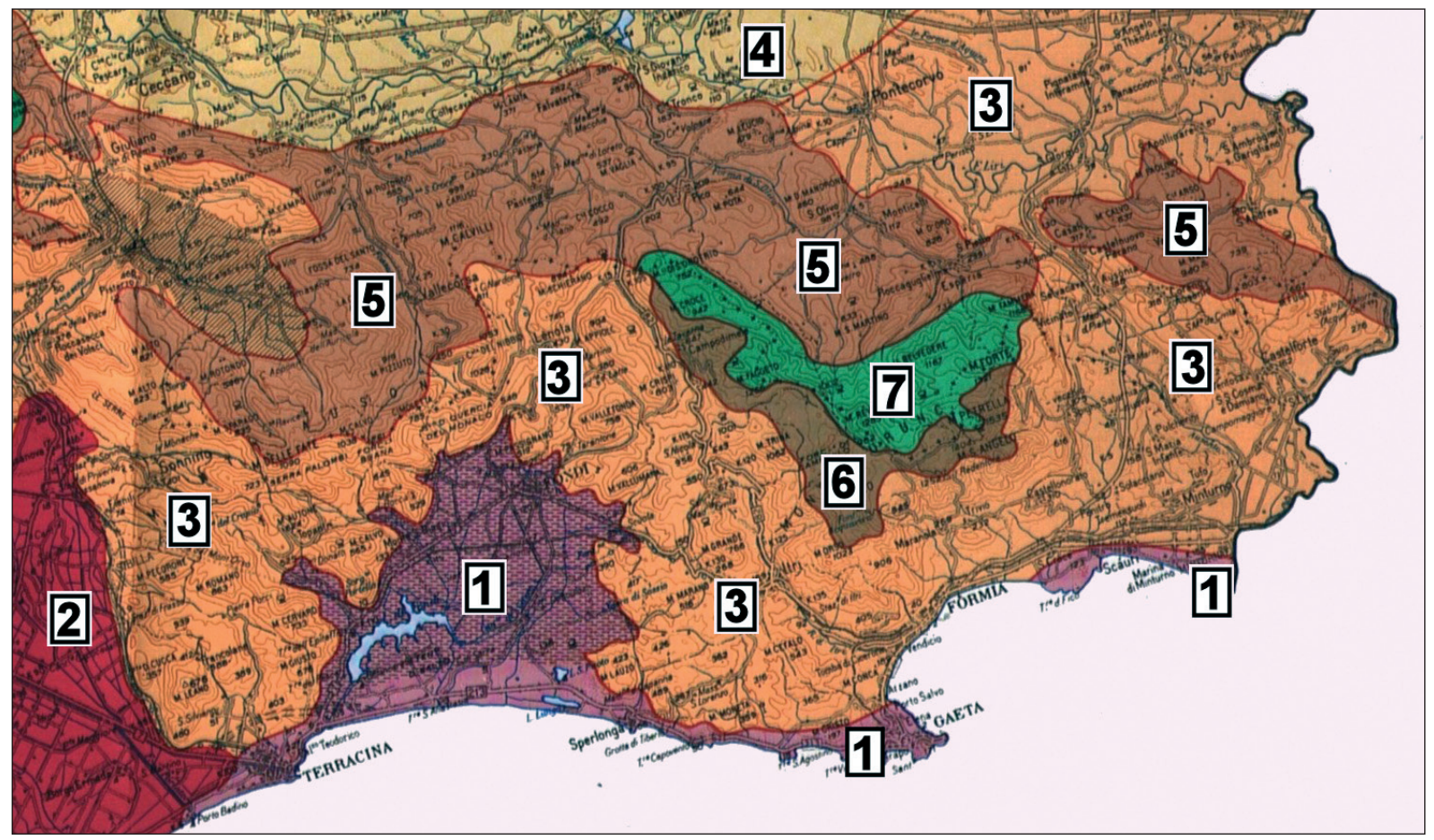

Figure 3: Phytoclimatic map of the Ausoni-Aurunci Mts. (From Blasi, 1994). Tt = Thermotype; Ut = Umbrotype. 1: Medit. Region, thermo-Medit. Tt. - lower humid/upper subhumid Ut.; 2: Medit. Region, lower meso-Medit. Tt. - upper subhumid Ut.; 3: Medit./Temp. transiction Region, upper meso-Medit. Tt. - lower humid Ut.; 4: Medit./Temp. transiction Region, lower hilly Tt. - lower humid Ut.; 5: Temp. Region, upper hilly Tt. - upper humid/lower hyperhumid Ut.; 6: Temp. Region, submontane Tt. - lower hyperhumid Ut.; 7: Temp. Region, lower montane Tt. - upper humid/lower iperhumid Ut.

Slika 3: Fitoklimatska karta hribovja Ausoni-Aurunci (Blasi 1994). Tt = termotip; Ut = ombrotip. 1: sredozemska regija, termosredozem. Tt. - spodnji humidni/zgornji subhumidni Ut.; 2: sredozemska regija, spodnji mezzo-sredozem. Tt. - zgornji subhumidni Ut.; 3: sredozem./zmerna prehodna regija, zgornji mezzo-sredozem. Tt. - spodnji humidni Ut.; 4: sredozem./zmerna prehodna regija, spodnji gričevnati Tt. - spodnji humidni Ut.; 5: zmerna regija, zgornji gričevnati Tt. - zgornji humidni/spodnji hiperhumidni Ut.; 6: zmerna regija, submontanski Tt. - spodnji hiperhumidni Ut.; 7: zmerna regija,spodnji montanski Tt. zgornji humidni/spodnji hiperhumidni Ut.

cies. Owing to the wide time range over which the relevés composing the synoptic table were performed (more than 40 years) and the impossibility of doing a taxonomical check on the older specimens, the reference to the collective group is given for all those taxa which could give rise to taxonomical uncertainity or which have only recently been split into different species and/ or subspecies (e.g. Koeleria lobata/K. splendens ${ }^{1}$,

\footnotetext{
${ }^{1}$ As far as Genus Koeleria is concerned, the use of the diagnostic-key proposed recently in Brullo et al. (2009) for identifying Ausoni-Aurunci grasslands specimens resulted in the identification of three or four different taxa (species and/or subspecies) belonging to Koeleria splendens collective complex as occurring in the same grassland type. Similar problems were encountered in identifying Koeleria specimens during the two excursions of the Floristic Group of the Italian Society of Botany (see Peruzzi et al. 2011; Conti et al. in prep.). The checklist of the Italian Flora (Conti et al. 2005) reports only Koeleria lobata
}

Bromus erectus/B. caprinus, Armeria canescens/A. majellensis, Potentilla pedata/P. hirta, Centaurea

(M. Bieb.) Roemer \& Schult. as reference taxon for the Italian Peninsula. This hypothesis, however, is considered wrong by Quintanar et al. (2009) who consider K. splendens to be a different taxon from $K$. lobata, which is the correct name of some other species (e.g. K. brevis Steven or $K$. degenii Domin). For this reason we have preferred to make reference to the collective form of the taxon Koeleria splendens. The Koeleria specimens coming from Sila mountains (Calabria region) were reported as $K$. spendens Presl by Bonin (1978), and as K. splendens C. Presl subsp. brutia Brullo, Gangale et Uzunov by Brullo et al. (2004). This fact has a direct consequence on the name of the alliance Koelerio-Astragalion, which in Brullo et al. (2005) is reported as Koelerio brutiae-Astragalion calabrici (see Syntaxonomic scheme). Obviously a correction of this name according to the Art. 43 of ICPN will be necessary if the subspecies Koeleria splendens subsp. brutia is definitively reported as synonym in the future by the main Floras and Checklists. 
deusta (ssp. pl.), Acinos alpinus (ssp. pl.), Festuca laevigata (ssp. pl.) (etc). The collected and exsiccated samples are deposited in the Herbarium Flaminio (Faculty of Architecture of the University of Rome).

The syntaxa here described as new have been named according to the International Code of Phytosociological Nomenclature (ICPN, Weber et al. 2000). Species which occur only once were excluded from both the phytosociological tables and the synoptic table, and are mentioned in Appendix 1. Place and date of relevés are listed in Appendix 2. The list of associations included in the synoptic table is reported in Appendix 4.

The lists of characteristic species of the higher rank syntaxa that are critically analysed in the paragraph "syntaxonomical discussion" are shown at the end of the paper after the "syntaxonomical scheme". The "characteristic species" of alliance and suballiances are reported in the phytosociological tables according to the following categories of species (Poldini \& Sburlino 2005):

"CHARACTERISTIC" (c): strongly related to the ecology and chorology of a given syntaxon.

"REGIONAL CHARACTERISTIC" (rc): having a distribution area wider than that of the syntaxon to which it is ecologically related.

"PARTIAL CHARACTERISTIC" (pc): having a distribution area smaller than that of the syntaxon to which it is ecologically related.

"TRANSGRESSIVE" ( $t$ ): species which, although considered as characteristic of a high-rank syntaxon, exhibit their ecological optimum in a lower rank syntaxon included in that high-rank syntaxon.

"INSGRESSIVE" (i): Species which, although considered as characteristic of a syntaxon of a different class, may occur frequently in a syntaxon of another class.

In agreement with Mucina et al. (2009), the characteristic species of the order ArtemisioBrometalia was reported as "provisional", since a wider classification that also takes into account the grassland communities of central and the south-eastern Europe is necessary to select a package of species which is ecologically and geographically consistent with the rank of order. The packages of characteristic species of the various associations making up the synoptic table are here reported acritically from the original papers. Critical comments are given in the "Discussion" paragraph.

\section{RESULTS}

\section{A Multivariate analysis (Restricted to Ausoni-Aurunai releves)}

The dendrogram (Figure 4) shows two main clusters (A and B). Cluster A includes the grasslands developed within the lower montane belt and dominated by the Koeleria splendensCarex humilis-Helianthemum incanum species group. Cluster B includes the Bromus erectus and Helichrysum italicum dry grasslands developed within the hilly and submontane belts of the Ausoni Mts. (B2) and Aurunci Mts. (B1) respectively. The PCA diagram on the first two axes (cumulative variance 18\%) calculated on presence/absence data (Figure 5) confirms the cluster analysis separation showing a clear division between clusters $\mathrm{A}$ and $\mathrm{B}$. This distribution of the clusters along the first PCA axis is correlated to an increasing altitudinal gradient, moving left to right.

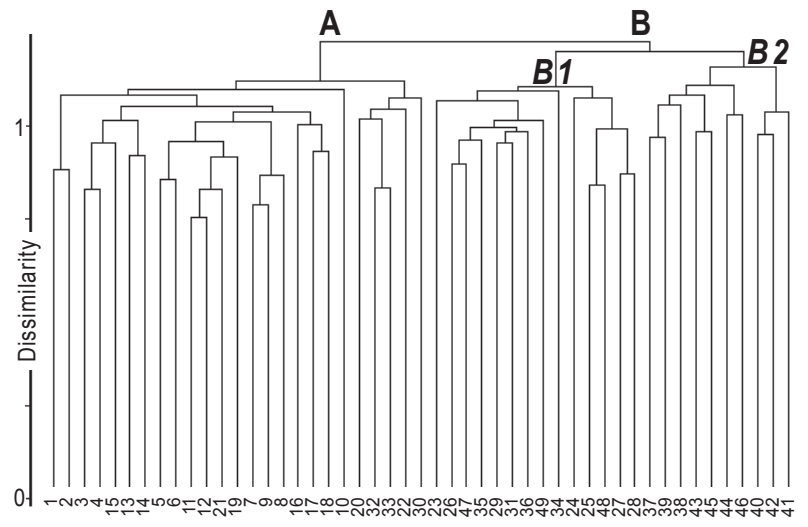

Figure 4: Cluster analysis dendrogram of Ausoni-Aurunci dry grasslands: cluster "A" = Violo-Koelerietum; cluster "B" = Helichryso-Brometum (“B1": subass. saturejetosum; "B2": subass. typicum).

Slika 4: Dendrogram klastrske analize suhih travišč hribovja Ausoni-Aurunci: klaster "A" = Violo-Koelerietum; klaster "B" = Helichryso-Brometum ("B1": subass. saturejetosum; "B2": subass. typicum).

\section{B Vegetation}

The two clusters of relevés identified through the multivariate analysis are referred to two new associations named respectively Violo pseudogracilis-Koelerietum splendentis ass. nov. (cluster A) and Helichryso italici-Brometum erecti ass. nov. (cluster B). 


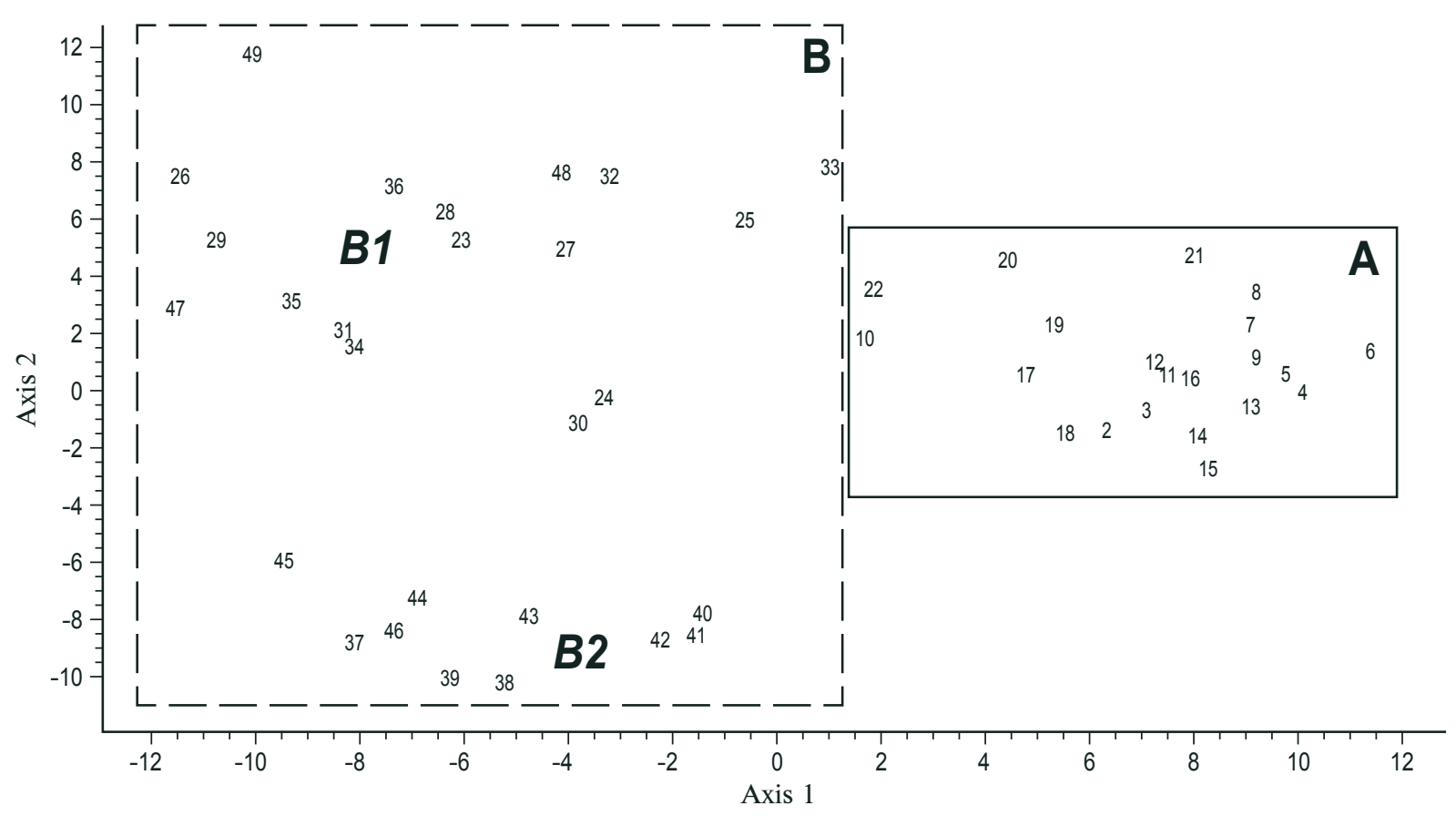

Figure 5: Ordination diagram (PCA) of Ausoni-Aurunci dry grasslands: cluster "A" = Violo-Koelerietum; cluster "B" = Helichryso-Brometum (B1: subass. saturejetosum; B2: subass. typicum).

Slika 5: Ordinacijski diagram (PCA) suhih travišč hribovja Ausoni-Aurunci: klaster "A" = Violo-Koelerietum; klaster "B" = Helichryso-Brometum (B1: subass. saturejetosum; B2: subass. typicum).

\section{4.b1 Violo pseudogracilis-Koelerietum splendentis ass. nov. hoc loco (Holotypus Table 1 rél. 2)}

CHARACTERISTIC SPECIES: Carex humilis, Festuca stricta subsp. trachyphylla, Viola pseudogracilis subsp. pseudogracilis, Seseli montanum, Thymus striatus.

DIAGNOSIS: Violo-Koelerietum is found to range in altitude between about $1000 \mathrm{~m}$ and the summit of the Aurunci mountains (Mt. Petrella 1,534 m a.s.l.) where it occurs on limestone southfacing slopes in the form of a secondary open dry grassland (Figure 6). On the basis of the phytoclimatic map of the Latium region (Blasi 1993) this grassland community is developed within the lower montane/upper submontane thermotypes and the humid/hyperhumid umbrotype (units 6 and 7 in Figure 3) in the Temperate Region. The soil is shallow, pure in humus and nutrients, while stonyness and rockyness are considerable. Because of the specific characteristics of limestone for infiltration of rain water the surface remains dry, and this is the reason for the presence of xerothermic Mediterranean species even at higher altitude. Although the floristic richness which leads one to observe a high number of coloured flowering plants in spring, the sward is scarce and almost completely dried out in the summer. There is not a single species which clearly dominates the community, although Koeleria splendens is the species showing the highest specific cover index. This species is constantly joined by other high frequency/abundance species such as Carex humilis, Heliathemum oelandicum subsp. incanum, Festuca stricta subsp. trachyphylla, Festuca inops and Thymus striatus. Of biogeographical interest is the abundance of Viola pseudogracilis, a rare species which exhibits a whole distribution area restricted to the southern part of the Tyrrhenian district of central and southern Italy. A variant with Sesleria juncifolia and Edrajanthus graminifolius is described for those sites which exhibit a higher degree of rockyness (Table 1 rél. 15-22).

CHOROLOGY AND STRUCTURE: Almost $50 \%$ of Violo-Koelerietum cover is due to the sum of the SE-European (s.s.) species and the SE-European orophytes ones (Table 5). On the contrary, very scarce is the role of the western chorotypes (here identified by the "Atlantic" 


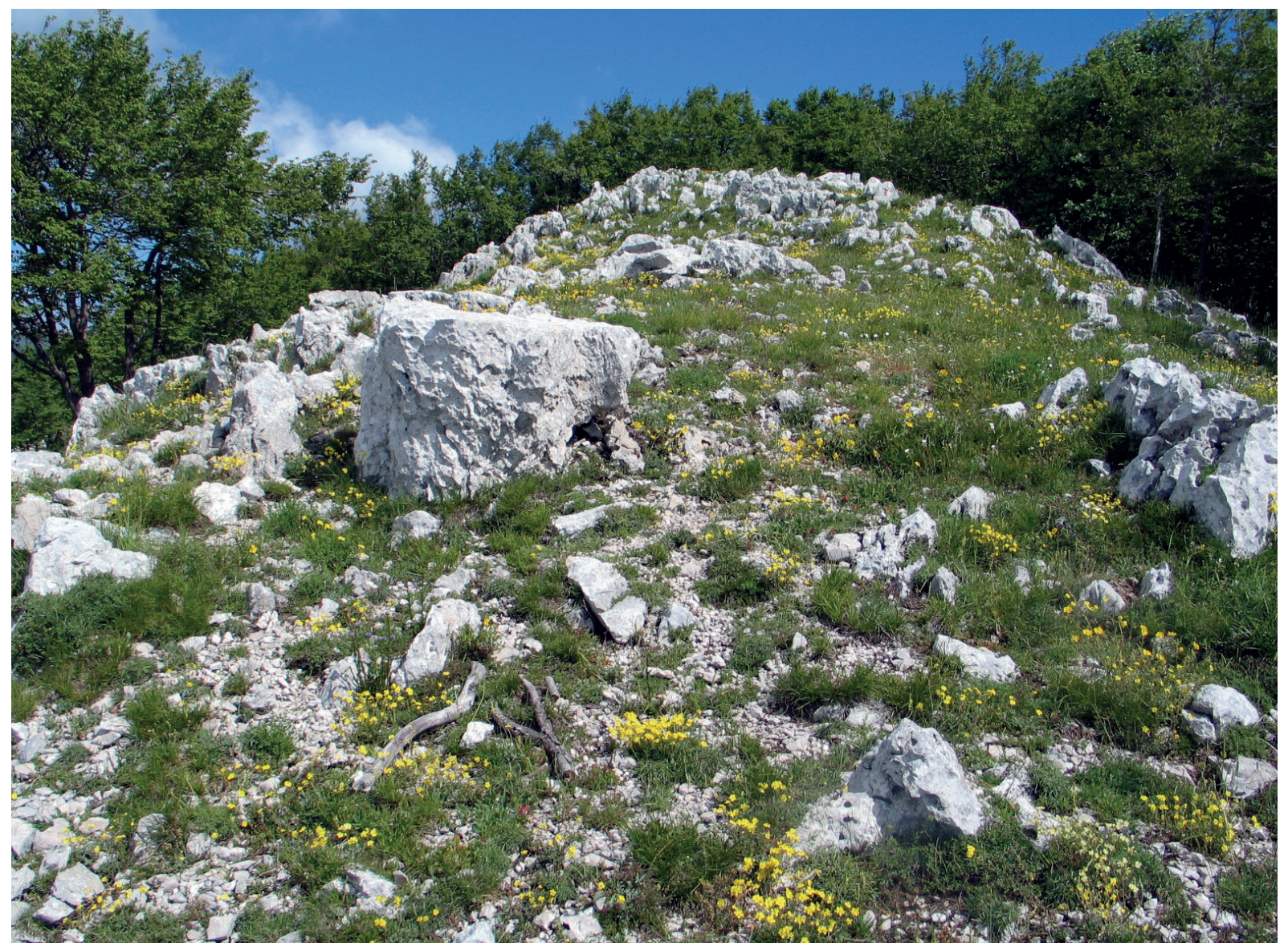

Figure 6: Violo pseudogracilis-Koelerietum splendentis in the Mount Revole (1100 m).

Slika 6: Violo pseudogracilis-Koelerietum splendentis na hribu Revole (1100 m).

component), although the biogeographic map of Europe (Rivas-Martínez et al. 2002) reports the Aurunci mountains as included in the Italo-Tyrrhenian Province together with the rest of western southern Italy, Sardinia, Corsica, Balearic Islands and Catalonia). The contributions of the Eurasiatics, European-Caucasians and Italian endemics are also important, whereas the percentages of the Mediterranean chorotypes (Eurimedit. + Stenomedit.) are relatively low and sharply decreasing, passing from the normal to the cover spectrum. Cosmopolitans are poorly represented since the few synanthropic species occurring in Violo-Koelerietum belong to the Steno/ Euri Mediterranean therophytic component. As far as the life form spectrum is concerned (Table 4), Violo-Koelerietum is mainly characterised by the hemicryptophytes, which are approached by chamaephytes observing frequency and cover values only. As expected, the contribution of the phanerophytes is negligible as well as that of the therophytes, which are about $20 \%$ of the overall species composition but which cover for $2 \%$ only.

Table 4: Life form spectra of Violo-Koelerietum and Helichryso-Brometum.

Table 4: Spekter življenskih oblik asociacij Violo-Koelerietum in Helichryso-Brometum.

\begin{tabular}{|c|c|c|c|c|c|c|}
\hline 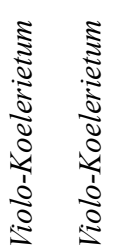 & 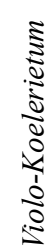 & 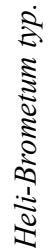 & 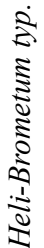 & 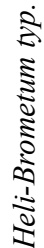 & 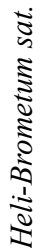 & 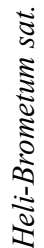 \\
\hline
\end{tabular}

Pres. Frq. Cov. Pres. Frq. Cov. Pres. Frq. Cov.

\begin{tabular}{lccccccccc} 
Ch & 20 & 32 & 37 & 9,1 & 15 & 31 & 14 & 19 & 26 \\
$\mathbf{G}$ & 9,3 & 6,6 & 3,3 & 13 & 8 & 6,9 & 8,2 & 4,8 & 3,7 \\
$\mathbf{H}$ & 45 & 52 & 58 & 40 & 38 & 53 & 39 & 47 & 56 \\
$\mathbf{P}$ & 2,5 & 1,4 & 0,3 & 9,8 & 9,6 & 2,5 & 9,6 & 4,7 & 3,9 \\
$\mathbf{T}$ & 23 & 8,3 & 2,1 & 29 & 30 & 7,5 & 29 & 25 & 11 \\
\hline
\end{tabular}


DYNAMISM: From a syndynamical point of view Violo-Koelerietum is related to thermophilous beech forests of Geranio versicoloris-Fagion at higher altitudes and mesophilous Ostrya capinifolia woods (Laburno-Ostryenion) at lower altitudes.

DISTRIBUTION: The Italian distribution of Violo-Koelerietum is restricted to the Aurunci mountains at present. However it is possible that similar communities could be found within the other coastal limestone massifs occurring southwards of the Aurunci mountains (Lattari Mts. and Castellamare Mts. in Campania Region) which exhibit quite similar physiographic and bioclimatic features.

\section{4.b2 Helichryso italici-Brometum erecti ass. nov. hoc loco \\ (Holotypus Table 2 rel. 6)}

Helichryso italici-Brometum erecti typicum subass. nov. hoc loco

Helichryso italici-Brometum erecti saturejetosum montanae subass. nov. hoc loco

(Holotypus Table 2 rel. 14)

CHARACTERISTIC SPECIES: Centaurea deusta, Centaurium erythraea, Helichrysum italicum, Melica transsylvanica, Micromeria graeca, Sedum sexangulare.

DIAGNOSIS: Helichryso-Brometum erecti (Figure 7) is a secondary dry grassland which is widespread in the upper part of the hilly belt and in the submontane belt (in some cases it can even exceed $1000 \mathrm{~m}$ as is the case of Mt. delle Fate, Mt.

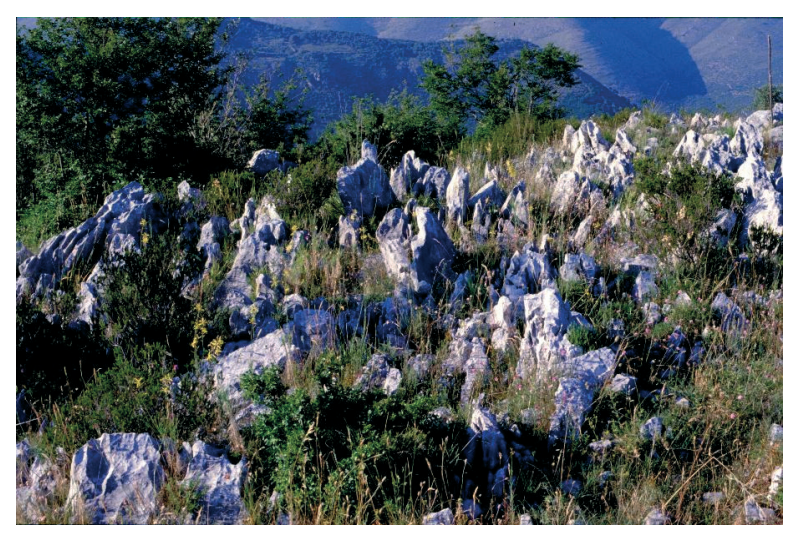

Figure 7: Helichryso italici-Brometum erecti saturejetosum montanae in the south facing slopes of Mount Fusco (650 m). Slika 7: Helichryso italici-Brometum erecti saturejetosum montanae na južnih pobočjih hriba Fusco (650 m).
Cervello and Mt. Fammera). Helichryso-Brometum finds its optimum in the meso-Mediterranean and upper hilly thermotypes with an upper subhumid umbrotype. From a coenological point of view Helichriso-Brometum erecti is characterised by the dominance of Bromus erectus, which is joined by other Brometalia erecti xerophilous grasses such as Koeleria splendens, Phleum hirsutum subsp. ambiguum, Festuca circummediterranea and F. stricta subsp. trachyphylla. Very frequent are also some micro-chamaephytes such as Thymus longicaulis, Teucrium chamaedrys, Helianthemum nummularium subsp. obscurum, and Helichrysum italicum (this latter, together with Erica multiflora, acts as a trait-d'union with the StenoMediterranean garrigues of the lower bioclimatic belts). In addition to the typical aspect (subass. typicum), a new subassociation named saturejetosum montanae is described to express the geographical separation between the Aurunci and Ausoni massifs. The characteristic species of this subassociation are selected in Satureja montana, Euphorbia spinosa subsp. spinosa, Linum tenuifolium. In particular Satureja montana and Linum tenuifolium are abundant in the Aurunci mountains (even at relatively low altitudes), whereas they are extremely rare in the Ausoni mountains where they are restricted to a few boundary areas only (Moraldo et al. 1990; Lucchese \& Lattanzi 2000). Of biogeographic relevance is the presence of Asphodeline liburnica, which although being a common species in southern Italy, finds its Tyrrhenian northernmost limit precisely in the Aurunci mountains.

CHOROLOGY AND STRUCTURE: Both chorological and life form spectra are very different from those of Violo-Koelerietum. Indeed, the Mediterranean chorological component (Eurimedit. + Stenomedit.) is significantly stronger, reaching about $50 \%$ in the three spectra. In particular the Stenomediterranean is the dominant chorotype (Table 5). Hemicryptophytes and Chamaephytes (52-55\% and $30-25 \%$ on the cover spectrum, respectively) still play a major role in the structure of the community but the contribution of therophytes is significantly higher than in Violo-Koelerietum, being about $30 \%$ of the whole specific composition and about $10 \%$ of the total cover.

DYNAMISM: On the north facing slopes Helichryso-Brometum is dynamically linked to thermophilous aspects of Melitto-Ostryetum or with Lonicero-Carpinetum orientalis woods. The mesophilous Quercus pubescens or Quercus ilex 
woods (Ostryo-Quercetum ilicis) are the potential vegetation types of the southern facing slopes.

DISTRIBUTION: In addition to the AusoniAurunci mountains, Helichryso-Brometum can also be found in other areas such as the limestone massifs surrounding the Rome area (Prenestini, Tiburtini, Cornicolani, Sabini, Lucretili), and in the hilly belt of inner massifs such as the Affilani, Simbruini-Ernici or Reatini mountains).

Table 5: Chorological spectra of Violo-Koelerietum and Helichryso-Brometum.

Table 5: Horološki spekter asociacij Violo-Koelerietum in Helichryso-Brometum.

\begin{tabular}{|c|c|c|c|c|c|c|c|c|c|}
\hline & 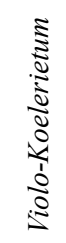 & 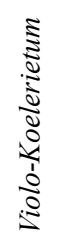 & 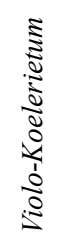 & 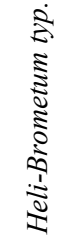 & 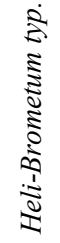 & 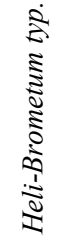 & 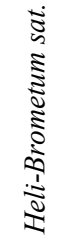 & 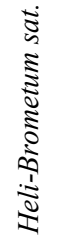 & 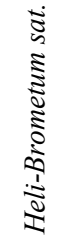 \\
\hline & Pres. & Frq. & Cov. & Pres. & Frq. & Cov. & Pres. & Frq. & Co \\
\hline Atlantic & 2,5 & 1 & 1 & 2,6 & 2 & 0,6 & 1,2 & 0,5 & 0,1 \\
\hline Boreal & 0,6 & 0,1 & 0,1 & 1,8 & 0,8 & 0,2 & 1,2 & 0,5 & 0,1 \\
\hline Endemic & 7,4 & 9,1 & 11,1 & 4,8 & 3,8 & 4,5 & 4,9 & 4,1 & 10,2 \\
\hline Eurasiat & 14,2 & 16,3 & 20,8 & 13,2 & 14,4 & 22,3 & 15,4 & 20,2 & 30, \\
\hline $\begin{array}{l}\text { Europ- } \\
\text { Caucas }\end{array}$ & 9,2 & 8,1 & 10,4 & 6,6 & 4,2 & 3 & 6,2 & 6,2 & \\
\hline $\begin{array}{l}\text { Oroph. } \\
\text { S-Europ. }\end{array}$ & 21,6 & 23,6 & 27,8 & 10,2 & 14 & 18,1 & 9,2 & 9,1 & \\
\hline SE-Europ & 14,2 & 18 & 20,2 & 9,7 & 11,8 & 8 & 9,2 & 9,3 & \\
\hline Euri-Medit. & 20,4 & 15,5 & 6,4 & 27,8 & 27,5 & 16,4 & 31 & 30,5 & 36,2 \\
\hline Steno-Medit. & 8,02 & 7,6 & 2,2 & 21,7 & 20,6 & 26,6 & 20,4 & 18,2 & 7,3 \\
\hline Subcosmop. & 1,85 & 0,5 & 0,08 & 1,3 & 0,6 & 0,2 & 1,2 & 1,2 & $\mathbf{0}$, \\
\hline
\end{tabular}

\section{G Multivariate analysis (synoptic TABLE)}

The synoptic table dendrogram (Figure 8) shows four main clusters. $(\mathrm{A}+\mathrm{B})$ : communities of the Tyrrhenian side of central Italy (Latium + Tuscany) with (A) Violo-Koelerietum (montane belt) clearly separated by (B)the more termophilous communities (hilly belt). (C): Bromus erectus hilly dry grasslands of the Adriatic side of central Italy mainly identifiable in Asperulo purpureae-Brometum, Potentillo cinereae-Brometum and TrigonelloSideridetum. (D): Fumano procumbentis-Stipetum appenninicolae. (E): Montane dry grasslands of the continental sector of the central Apennines (Mount Velino) described through the associations Saturejo montanae-Brometum erecti, Onobry-

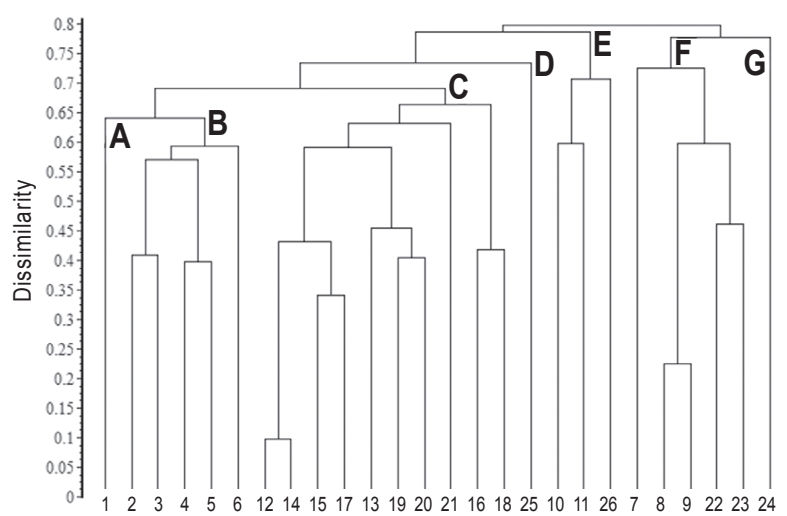

Figure 8: Cluster analysis dendrogram of the synoptic columns of the central Apennines main types of dry grasslands. A: Violo-Koelerietum; B: Helichryso-Brometum + CerastioBrometum; C: Asperulo purpureae-Brometum + Potentillo cinereae-Brometum group. D: Fumano-Stipetum; E: SaturejoBrometum + Onobrychido-Brometum + Lavandulo-Asphodelinetum; F: Plantago-Heliantemetum + Koelerio splendentisBrometum + Polygalo majoris-Brometum. G: Seslerio nitidaeBrometum.

Slika 8: Dendrogram klastrske analize sinoptične tabele glavnih tipov suhih travišč v srednjih Apeninih. A: Violo-Koelerietum; B: Helichryso-Brometum + Cerastio-Brometum; C: Asperulo purpureae-Brometum + Potentillo cinereae-Brometum group. D: Fumano-Stipetum; E: Saturejo-Brometum + Onobrychido-Brometum + Lavandulo-Asphodelinetum; F: Plantago-Heliantemetum + Koelerio splendentis-Brometum + Polygalo majoris-Brometum. G: Seslerio nitidae-Brometum.

chido albae-Seslerietum nitidae together with Pollino's Lavandulo-Asphodelinetum. (F) dry grasslands and micro-garrigue of the montane belt of the central Apennines which are enriched in Elyno-Seslerietea companion species, and which are identifiable in Polygalo majoris-Brometum erecti, Koelerio splendentis-Brometum erecti and Plantago holostei-Helianthemetum cani. (G) Dry grasslands of the montane belt of the Umbrian-Marches Apennines (Seslerio nitidae-Brometum erecti).

\section{SYNTAXONOMICAL DISGUSSION}

\section{5a Comparison between the Ausoni- AURUNGI NEW ASSOGIATIONS AND SIMILAR ASSOCIATIONS OCGURRING IN Peninsular ItAly.}

The most important result of this paper is that two new dry grassland associations have been identified for Peninsular Italy. According to Biondi et al. (2005) the coenological group of the 
Apennines dry grasslands already includes 37 associations (counting solely those included in the endemic alliance Phleo-Bromion). Actually, to propose yet further types and names to be inserted in a syntaxonomical box which probably already contains too much, may appear somewhat paradoxical. Nevertheless, it is the opinion of the author that these new associations have the appropriate floristic, coenological and nomenclatural requirements to enable them to "carve out" an ecological space for themselves in the Italian dry grasslands syntaxonomical framework - despite the fact that they display similarities to some other central Apennines dry grasslands types.

Violo pseudogracilis-Koelerietum splendentis exhibits physiognomical similarities to the association Plantago holostei-Helianthemetum cani, described for the stony pastures of Campo Imperatore (Gran Sasso range) at altitudes ranging between $1560 \mathrm{~m}$ and $1740 \mathrm{~m}$ (Biondi et al. 1992; 1999). High altitudes and geographical location make Plantago-Helianthemetum rich in species (Carex kitaibeliana, Iberis saxatilis, Brachypodium genuense, Draba aizoides, Centaurea ambigua, Sedum atratum, Anthemis cretica ecc.) which are common in the subalpine belt of the Apennines, but absent in the coastal mountains. For the same reason PlantagoHelianthemetum lacks the entire characteristic component of Violo-Koelerietum with the sole exception of Carex humilis.

Both Violo-Koelerietum and Helichryso-Brometum exhibit some similarities with Saturejo montanae-Brometum erecti Avena \& Blasi 1979. Saturejo-Brometum was one of the first associations to be described for the central Apennines, and, as a consequence, it was taken as the reference for several other central and southern Apennine areas (Avena \& Blasi 1980; Abbate et al. 1984; Biondi \& Blasi 1984; Francalancia \& Orsomando 1981; Corbetta 1984; Corbetta et al. 1984; Petriccione 1993; Lucchese et al. 1995; Tammaro 1995; Blasi et al. 1998, Maiorca \& Spampinato 1999). In Lucchese et al. (1995) Saturejo-Brometum erecti was considered practically the only perennial dry grassland association of the Latium region, distributed from the core of the central Apennines to the coastal mountains (therefore including the Ausoni-Aurunci mountains too). According to these authors Saturejo-Brometum was divided into two distinct subassociations: $S-B$ medicaginetosum, (thermophilous and occurring at altitudes ranging between 300 and $700 \mathrm{~m}$ ) and $S-B$ leontodontidetosum (occurring at higher altitudes up to $1400 \mathrm{~m}$ ). This diagnosis, however does not correspond to the original diagnosis of SaturejoBrometum made by Avena \& Blasi (1979), which described a rich-in-chamaephytes dry pasture restricted to the montane belt of Mount Velino (the most "continental" massif of the central Apennines). Indeed the specific component of Saturejo-Brometum included several taxa (Sideritis italica, Plantago sempervirens, Cerastium tomentosum, Euphorbia myrsinites, Asperula cynanchica, Arctostaphylos uva-ursi) which, although common in that area, were absent or extremely rare in the warmer and suboceanic mountains of the Tyrrhenian coastal district. In fact, the Tyrrhenian district is very rich in Mediterranean thermophilous perennial and annual species (Helichrysum italicum, Micromeria graeca, Convolvulus cantabrica, Medicago minima, Carlina corymbosa, Urospermum dalechampii, Bupleurum baldense, Trifolium scabrum, Coronilla scorpioides, Trachynia distachya, Crupina vulgaris, etc.) which are extremely rare in the core of the Apennines. As a consequence, the two "hilly-submontane tyrrhenian" subassociations of Saturejo-Brometum hypothesized by Lucchese et al. (1995) for the Ausoni-Aurunci mountains are quite unlikely. The synoptic table dendrogram (Figure 8) shows that both SaturejoBrometum leontodontetosum and Saturejo-Brometum medicaginetosum (coll. 4 and 5 respectively) are floristically closer to Helichryso-Brometum (coll. 2 and 3) than to Saturejo-Brometum sensu Avena \& Blasi 1979 (col. 10). Hence, it is probable that Saturejo-Brometum medicaginetosum and Saturejo-Brometum leontodontetosum p.p. should be included in Helichryso-Brometum, while only those few relevés of the subass. leontodontetosum performed in the core of the central Apennines, could possibly be included in the true SaturejoBrometum.

An association which shows similarities to Helichryso-Brometum is Cerastio etrusci-Brometum erecti, which was described in central and southern Tuscany (Angiolini et al. 2005). On the basis of the distribution of Cerastium arvense var. etruscum (according to Angiolini et al. 2005 this entity is restricted to the limestone massifs of central and southern Tuscany), and of the presence of some other species which are absent or rare in Helichryso-Brometum (Santolina etrusca, Marrubium incanum, Erysimum pseudorhaeticum, Eryngium campestre, Melica ciliata, Alyssum minus), this association behaves as a northern Tyrrhenian vicariant of Helichryso-Brometum. Observing the 
rest of the characteristic species of Cerastio-Brometum (Carlina corymbosa, Festuca inops, Convolvulus cantabrica) and the whole syndistribution of the association (Tyrrhenian district of central Italy) there is a possibility that Cerastio-Brometum and Helichryso-Brometum might be considered as syntaxonomical synonyms in the future, especially if the taxonomical dubiousness surrounding the taxon Cerastium arvense var. etruscum is ever resolved (both Pignatti (1982) and Conti et al. (2005) refer this entity to Cerastium scarani Ten., while Barberis et al. (1995), Miceli et al. (1997), and Bechi (1998) refer C. arvense var. etruscum to the group of Cerastium arvense subsp. arvense).

Another association widely used in the phytosociological literature to describe thermophilous dry grasslands of the central Apennines is Asperulo purpureae-Brometum erecti. This association was originarily proposed to descibe the hilly belt dry pastures of Mount Catria (northern Marches Apennines) but subsequently was extended to the whole of the Umbrian-Marches Apennines and surrounding areas (Biondi \& Ballelli 1981; Ballelli \& Biondi 1982; Biondi \& Ballelli 1982; Biondi et al. 1995). The characteristic species were selected to be Asperula purpurea, Eryngium amethystinum, Allium sphaerocephalon, Crepis lacera and Dianthus ciliatus. The first four species are rather common in most of the central Apennines dry grasslands communities occurring on limestone, whereas Dianthus ciliatus exhibits a higher diagnostic role since it is an amphi-adriatic element restricted to the eastern side of the central Apennines (from the Marches to Apulia) and completely absent from the Tyrrhenian district. The presence of Dianthus ciliatus in Asperulo-Brometum, together with that of other species which are absent from the Ausoni-Aurunci mountains (Asperula cynanchica, Trinia glauca, Poa alpina, Artemisia alba, Centaurea ambigua, Avenula pratensis s.l.), prevent Asperulo-Brometum from being used as syntaxonomical reference for the Ausoni-Aurunci communities (this is also confirmed by the cluster analysis of Figure 8).

As far as the higher rank syntaxa are concerned the first dilemma is to choose between the classes Festuco-Brometea and Rosmarinetea/CistoMicromerietea which are closely related to each other in the central Apennines both in floristic and coenological terms (Biondi et al. 2005). It is known that the structural parameters of communities deduced by the life forms spectra can provide useful elements to be added to the coe-
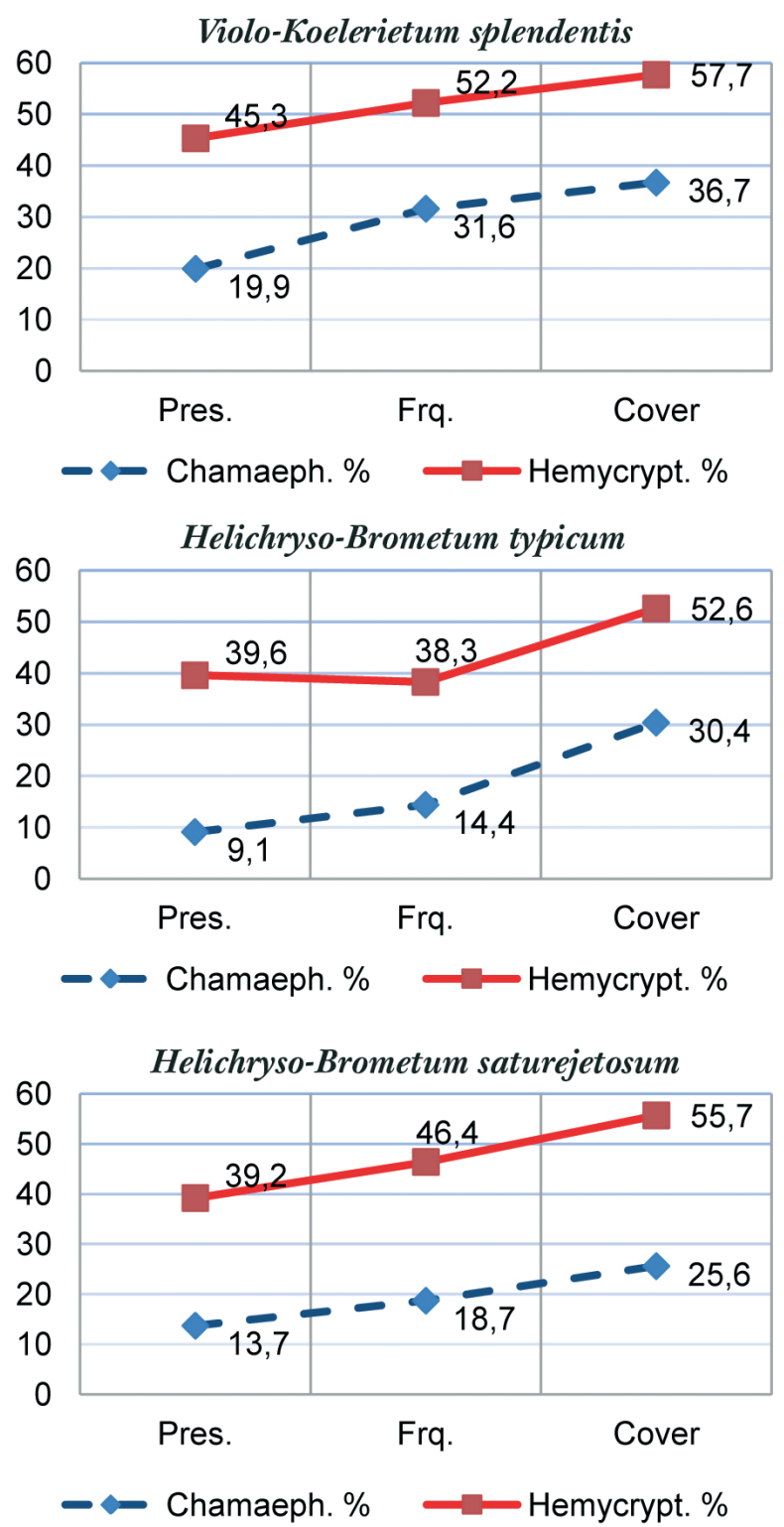

Figure 9: Life form graphics showing a comparison between the Hemycryptophytic and Chamaephytic component in the three types of spectra in both Violo-Koelerietum and Helichryso-Brometum.

Slika 9: Primerjava deleža hemikriptofitov in hamefitov v treh spektrih $\mathrm{v}$ asociacijah Violo-Koelerietum in HelichrysoBrometum.

nological diagnosis (Blasi et al. 2005; Di Pietro et al. 2008). As mentioned previously, Violo-Koelerietum splendentis and Helichryso-Brometum erecti are composed of a mixture of hemicryptophytes and chamaephytes, so their syntaxonomical position in the Apennines' context can be considered as intermediate between Phleo-Bromion (Festuco-Brometea) and Artemisio-Saturejion (Cisto-Micromeriet- 
ea). The physiognomical and structural distinction between these two alliances is not evident because their communities tend to be developed in similar environments and share a large number of micro-chamaephytes (Teucrium montanum, T. chamaedrys, T. capitatum, Dorycnium hirsutum, Micromeria graeca, Thymus striatus, T. longicaulis, Plantago holosteum, Helianthemum nummularium s.l., Helianthemum oelandicum s.l. Fumana procumbens, Euphorbia spinosa, Aethionema saxatile, Satureja montana etc.) which may exhibit similar frequency/cover indexes passing from Phleo-Bromion communities to Artemisio-Saturejion ones. In the specific case of Violo-Koelerietum and Helichryso-Brometum, the reference to FestucoBrometea appears to be the most appropriate. In fact, in both communities a grass species which shows the highest specific cover index (Koeleria splendens and Bromus erectus resp.). Furthermore, in the structural diagrams (Figure 9) the curve related to the presence, frequency and cover degree of the hemicryptophitic component is above the parallel curve of chamaephytes and never intersects it.

\section{B Nomenclatural issues}

The name Saturejo montanae-Brometum erecti was invalidly described in Avena \& Blasi 1979 (Art. 5). A further lectotypification of this name was provided in Biondi et al. (1995), identifying rel. 3 of Table 3 in Avena \& Blasi 1979 as the lectotype. Although this lectotypification was formally not in accordance with the rules of the Code (since Saturejo-Brometum was published after 1/1/1979) it can nevertheless be used to validate the name (Art. 6) since the lectotypus provided in Biondi et al. 1995 is the true holotypus of Saturejo montanaeBrometum erecti Avena \& Blasi ex Biondi, Ballelli, Allegrezza \& Zuccarello 1995. The two subassociations (Saturejo-Brometum medicaginetosum and Saturejo-Brometum leontodontetosum), proposed in the same issue (Fitosociologia 30, 1995) by Lucchese et al. (1995), and all the new subassociations described - subsequently making reference to the name Saturejo-Brometum Avena \& Blasi 1979 - are to be considered invalid (Art. 4 a).

The name Asperulo purpureae-Brometum erecti was proposed invalidly in Ballelli \& Biondi (1981) due the lack of the nomenclatural type (Art. 5). The nomenclatural type was subsequently provided in Biondi et al. (1995), but unfortunately still invalidly (Art. 2), because it made reference to rel. 6 in Table 3 in Biondi \& Ballelli (1982), even though this table was composed of a single synoptic column only. The reference to Ballelli \& Biondi made in the synoptic table's footnote and in the bibliographic list is not in accordance with the ICPN note 3 of Art. 2. The proposal of the new subassociation Asperulo purpureae-Brometum erecti asperuletosum purpureae as a typical subassociation of Asperulo purpureae-Brometum made in Allegrezza (2003) is also to be considered as invalid, since it makes reference to the same wrong type-relevé provided in Biondi et al. (1995). This nomenclatural deficiency of Asperulo-Brometum was already pointed out in Catorci et al. (2007), but these authors did not to provide the necessary corrections. Moreover, this is not the only nomenclatural problem affecting Asperulo-Brometum. In fact, this name was proposed as new in Biondi et al. (1995), with the addition of two new subassociations: teucrietosum montani and sideridetosum syriacae. This latter was obtained by lowering the rank of the association Trigonello-Sideritidetum syriacae Hruska 1982 (indeed the type-relevée designed for Asperulo-Brometum sideritidetosum subass. nov. was the same as that provided originally for Trigonello-Sideritidetum in Hruska 1982). In this way a union of syntaxa of the same rank (Trigonello-Sideritidetum Hruska 1982 and Asperulo-Brometum Biondi et al. 1995) was established with nomenclatural priority being assigned to Trigonello-Sideridetum (Art. 25, 26). Summarizing, despite the common use of $A s$ perulo purpureae-Brometum as a syntaxonomical reference for the Marches-Umbrian Apennines dry grasslands, it is at present to be considered both a nomen invalidum (Art. 5) and a nomen illegitimum (Art. 29c).

Biondi et al. (1995) designated Asperulo purpureae-Brometum erecti Biondi et al. 1995 as the nomenclatural type of the alliance Phleo ambiguiBromion erecti. The ascertained invalidity of $A s$ perulo-Brometum has direct repercussions on the alliance Phleo-Bromion, which is, likewise, to be considered invalid (Art. 5, 17). As a consequence it is necessary to find the prior valid published name, which can be used in place of Phleo-Bromion. On the basis of the nomenclatural and coenological features of Phleo-Bromion the most suitable name turns out to be Cytiso-Bromion erecti Bonin 1978 (... which is older than Phleo-Bromion and thus is even suitable to be used as a prior syntaxonomical synonym). The Italian phytosocio- 
logical literature has not treated this alliance in a uniform manner. In some cases (Biondi et al. $1995 ; 2005)$ it has been relegated to the Calabrian Apennines (in spite of the original diagnosis which explicitly designated the whole centralsouthern apennines as syndistribution area of the alliance), while in other cases it has merely been considered as not validly published (Brullo et al. 2004). The need for shedding light on this topic can be explained as follows: Cytiso-Bromion erecti was proposed in Barbero \& Bonin 1969 (sub Cytiso-Bromion caprini) as including the montane dry grasslands of central and southern Italy. In that paper the authors stated that Cytiso-Bromion caprini was identical (although with a wider distribution area) to Koelerio-Astragalion Giacomini \& Gentile 1966, an alliance which described the dry grasslands and garrigiues developed on the siliceous substrates of Sila plateau in Calabria region (Giacomini \& Gentile 1961; 1966). However, this first proposal of Cytiso-Bromion caprini was invalid (Art. 3,5) since no reference to a valid lower-rank syntaxon was provided. It was only in Bonin (1978) that a list of eight grassland and/ or garrigue associations belonging to Cytso-Bromion erecti (new name) and the list of characteristic species were presented, together with a more complete and emended diagnosis of the alliance. Amongst the associations included in Cytiso-Bromion, only one (Astragaletum calabri) was related to siliceous, poor-in-carbonates, substrates, while the remainder (Lavandulo-Asphodelinetum luteae, Paronichyo-Astragaletum sempervirentis, Onobrychido-Seslerietum nitidae, Eryngio amethystiniPolygaletum majoris, furineo mollis-Crepidetum rubrae, Cisto incani-Phlomidetum herba-venti, Helichryso italici-Teucrietum montani) were communities developed on the limestone substrates of the central and southern Apennines (in truth, in the same paper the alliance Cytiso-Bromion was also used to include some aspects of woody vegetation such as Genisto sericeae-Pinetum nigrae (nom. illeg. Art. $29 \mathrm{~b}$ ) which are difficult to refer to grassland syntaxa). According to Brullo et al. (2004) both Koelerio-Astragalion Giacomini \& Gentile 1966 and Cytiso-Bromion erecti Bonin 1978 were to be considered as invalid (resp. Art. 8 and Art. 1). Koelerio-Astragalion is effectively invalid (Art. 8), since neither of the two names proposed as new by Giacomini \& Gentile (1966), which were suitable to be used as nomenclatural type of Koelerio-Astragalion (Astragaletum calabrici and Foenicolo-Festucetum spadiceae), was validly published (Art. 7).
However, the question concerning Cytiso-Bromion caprini, which was proposed invalidly (Art. 3b, 8) in Barbero \& Bonin (1969), but further emended and validly proposed as Cytiso-Bromion erecti ten years later (Bonin, 1978), is somewhat different. The fact that this name was published in a Ph.D. thesis does not lead to its automatic invalidation. In fact, Bonin's Ph.D. thesis is to be considered as perfectly in accordance with art. 1 of ICPN, seeing that it was a printed book (not a photocopy) which was formally and legally deposited (Figure 10) in libraries accessible to botanists (e.g. it is regularly quoted in the bibliography of Avena \& Blasi, 1979 where the new association Saturejo-Brometum erecti was proposed). Because Cytiso-Bromion was published before 1.1.1979 it is suitable to be lectotypified. The lectotypus of the alliance Cytiso spinescentis-Bromion erecti was designed in Ubaldi (2011) using the association $L a$ vandulo-Asphodelinetum luteae Bonin 1978. (Bonin (1978) pages: 146; (complete description pp. 148153). The lectotypus of Lavandulo-Asphodelinetum luteae Bonin 1978 is selected hoc loco in rel. 509 of Table 21 in Bonin (1978), whose taxonomically updated version (based on the Italian checklist of Conti et al. 2005) is reported in Appendix 5. The characteristic species of Lavandulo-Asphodelinetum luteae originally defined by the author were Lavandula angustifolia, Asphodeline lutea, Leontodon crispus and Satureja montana.

CENTRE REGIONAL DE DOCUMENTATION PEDAGOGIQUE
Service d'Impression - 55, Rue Sylvabelle - 13006 MARSEILLE
Dépòt légal : 3ème trim. 1978

Figure 10: Title page (tables and figures) of Bonin's PhD Thesis with the reference to the publisher office and to the legal date of publishing.

Slika 10: Naslovnica (tabele in slike) doktorske naloge Bonina z oznako založnika in datumom izdaje.

The lectotypification of Cytiso-Bromion erecti means that most of the dry grassland associations previously included in Phleo ambigui-Bromion erecti Biondi et al. 1995 (nom. inval.) can easily be included in Cityso-Bromion erecti Bonin 1978, which thus assumes the role of reference alliance for the hilly and montane grasslands endemic to the central-southern Apennines. According to Bonin 1978, Cytiso-Bromion erecti included all the montane dry grasslands and micro-chamaephitic garrigues of the central and southern Apennines on both siliceous and limestone substrates. The 
geographical and ecological range of Cytiso-Bromion, as conceived by Bonin (1978), definitely appears too wide for a single alliance. The biogeographical boundary which runs between the Pollino-Orsomarso massif (limestone) and Sila massif (granites and gneiss) separates two geographical districts which are different not only in respect of geological and edapho-morphological features, but also in respect of paleogeographic and paleobotanic vicissitudes which have led to clear floristic and coenological differences. On the one hand, there are several calcicolous species whose southernmost limit in Peninsular Italy corresponds to the Pollino limestone massif (Sesleria nitida, Carex macrolepis, Sideritis italica, Euphorbia myrsinites, Globularia meridionalis etc.), while on the other hand there is a group of acidophilous species which are endemics of the siliceous massifs of southern Calabria (Sila, Serre calabre and Aspromonte), or which are simply absent from the calcareous sector of the Apennines (Astragalus parnassi subsp. calabrus, Armeria brutia, A. aspromontana, Avenula praetutiana subsp. rigida, Anthemis cretica subsp. calabrica, Hypericum calabricum, Genista silana, Centaurea sarfattiana). For this reason the distribution area of Cytiso-Bromion erect $i$ is restricted to the central-southern Apennines from the northern Marches to northern Calabria (Orsomarso mountains). On the basis of this new coenological and synchorological diagnosis of CytisoBromion erecti, the central Apennines endemic alliance Seslerio-Caricion macrolepidis proposed in Ubaldi (1997) is to be considered a syntaxonomical synonym, together with (at least partially) Botriochloo-Bromion erecti, which was proposed as new in the same paper. At the same time, to be considered syntaxonomical synonyms of Cytiso-Bromion (see the syntaxonomical scheme) are the following alliances: Knautio calycinae-Bromion caprini Ubaldi 2011, Sideritidion italicae (Biondi et al. 1995) Ubaldi 2011, proposed subsequently in Ubaldi (2011) and Violo pseudogracilis-Bromopsion caprinae Terzi 2011 (Terzi 2011).

The dry grasslands and garrigues occurring in the mountain ranges of the Calabrian Arc (especially Sila plateau) and developed on a great variety of siliceous substrates, belong to a different alliance. According to Brullo et al. (2005) this alliance is Koelerio-Astragalion Giacomini \& Gentile ex Brullo et al. 2005. The nomenclatural type of Koelerio-Astragalion was designated as Astragaletum calabrici Giacomini \& Gentile ex Brullo in Brullo et al. 2005. On the basis of ICPN, how- ever, Astragaletum calabrici Giacomini \& Gentile ex Brullo in Brullo et al. 2005 is an illegitimate and superfluous name (Art. 29b, 29c) beside being a heterotypic later homonym (Art. 31) of the name Astragaletum calabrici Giacomini \& Gentile ex Bonin 1978 (which is mentioned as synonym in Brullo et al. 2005). According to ICPN, however, this fact do not invalidate the name of the alliance (Art. 17). As regards the name Astragaletum calabrici it was proposed invalidly by Giacomini \& Gentile (1966) but subsequently validated by Bonin (1978) through a complete description of the association (pag. 140-145), including a phytosociological table composed of 10 reléves and the list of characteristic species. For this reason the association Astragaletum calabrici Giacomini \& Gentile ex Bonin 1978 (which lectotypus is selected hoc loco in rel. 628 of Table 16 in Bonin 1978 and which taxonomically updated version,

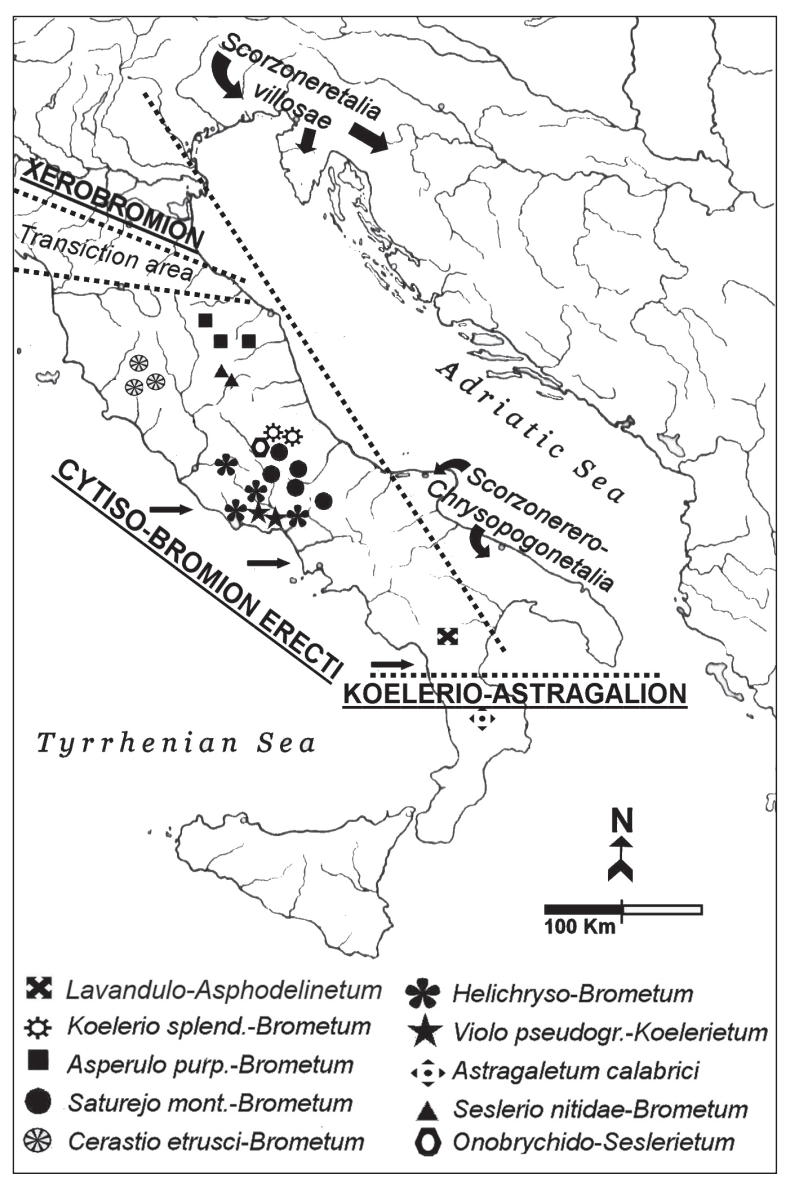

Figure 11: Distribution of the main alliances of dry grasslands in Peninsular Italy.

Slika 11: Razširjenost glavnih zvez suhih travišč Italijanskega polotoka. 
based on the Italian checklist of Conti et al. 2005, is reported in Appendix 5) take the role of nomenclatural Typus of the alliance Koelerio-Astragalion. The choice of Astragaletum calabrici Giacomini \& Gentile ex Bonin 1978 as type-association of Koelerio-Astragalion leaves open the problem of the choice of class in which to include this alliance. According to Barbero \& Bonin (1969) this alliance had to be referred to Seslerietalia tenuifoliae, while Bonin (1978) included it in Scorzonero-Chrysopogonetalia, Brullo et al. (2004; 2005) in Rumici-Astragaletea siculi and Ubaldi (2011) in Cerastio-Carlinetea nebrodensis. As mentioned previously, the floristic-coenological boundary between a chamaephytic class (Rosmarinetea or Rumici-Astragaletea) and an hemicryptophytic one (Festuco-Brometea) is almost indistinguishable, especially in the Apennine montane dry grasslands or micro-garrigues. The phytosociological table of Astragaletum calabrici as reported in Bonin (1978) would suggest the inclusion of Koelerio-Astragalion in a chamaephytic class, since all the species showing the highest frequency and cover degree (Astragalus parnassi subsp. calabricus, Cytisus spinescens, Plantago serpentina, Thymus longicaulis and Helianthemum nummularium) are chamaephytes. At any rate, it is likely that only a wider-scale study able to merge the floristic and coenological data with ecological, paleobotanical and paleogeographical considerations could provide a plausible solution to this intricate question. (Figure 11 reports the map distribution of the main perennial dry grassland syntaxa in Peninsular Italy).

\section{C Coenological and Syntaxonomi- CAL FRAMEWORK OF CYTISO SPINES- CENTI-BROMION ERECTI}

According to Bonin (1978) Cytiso-Bromion erecti was restricted to the montane dry grasslands of the central and southern Apennines. Ubaldi (1997) referred Cytiso-Bromion to the montane dry grasslands of the southern Apennines, leaving those of the central Apennines to SeslerioCaricion macrolepidis (montane belt) and PhleoBromion (hilly belt). According to Biondi et al. (1995), Cytiso-Bromion was restricted to southern Italy, too, but the dry grasslands of the central Apennines were all included in the single alliance Phleo-Bromion. It is also my opinion that the central-southern Apennine dry grasslands on limestone cannot be divided at alliance level. In fact, the geographical location of the Apennine range, slicing as it does right through to the middle of the Mediterranean Sea, is responsible for a marked upward shift of Lygeo-Stipetea and Cisto-Micromerietea Mediterranean steppe-like grasslands and garrigues merged with Tuberarietea guttatae grasslands, which in some cases are widespread up to the lower montane belt (especially on the Tyrrhenian coastal side of Peninsular Italy). This upward altitudinal shift of Mediterranean species and communities strongly reduces the coenological space for the FestucoBrometea perennial dry grasslands which, moreover, also find themselves effectively competed with by Seslerietalia tenuifoliae communities in the upper montane belt and by Cynosurion communities in the intramontane plateaus. The different ecological and geographical enlargement of Cytiso-Bromion erecti (with respect to Bonin's 1978 proposal) requires a consequent enlargement in the list of the characteristic species of the alliance, which were selected by Bonin as comprised solely of Bromus erectus, Cytisus spinescens, Phleum hirsutum subsp. ambiguum and Centaurea deusta (Bonin 1978: 142), although other species, Thymus striatus, Sideritis italica, Asperula purpurea, Centaurea ambigua, Polygala major, Globularia meridionalis, Onobrychis alba were added as differentials in the various phytosociological tables. The new list (which is provided at the end of this paper and which only partially corresponds to the list proposed in Biondi et al. 1995 for Phleo ambigui-Bromion erecti) is composed of a core of endemic central-southern apennine species (testifying to a clear separation from the CS-European Xerobromion) and of a group of xerophitic species having a largely southeastern-European distribution.

As for the rank of suballiance, it has been necessary (for ecological and nomenclatural reasons) to dissect and reassemble what was proposed in previous papers, trying, where possible, to maintain the use of the old syntaxon names rather than propose new ones.

The phytosociological literature reports only a single suballiance for Cytiso-Bromion, namely, Plantaginenion serpentinae Bonin 1978. This suballiance was typified by Astragaletum calabrici and was restricted to those communities developed on siliceous substrates which were subsequently included in Koelerio-Astragalion. Instead, the following three suballiances were proposed in $\mathrm{Bi}$ - 
ondi et al. (2005) for Phleo-Bromion erecti: PhleoBromenion (hilly belt of the Marches-Umbrian Apennines), Brachypodenion genuensis (upper montane belt of central Apennines), Sideridenion italicae (recte: Sideritidenion italicae) (montane belt of southern Apennines). As mentioned previously, Phleo-Bromenion is to be considered invalid (Art. 17), while Brachypodenion genuensis and Sideritidenion italicae are validly described. Although Sideritidenion italicae was proposed as centered in the southern Apennines, its nomenclatural type (Saturejo montanae-Brometum erecti) is located in the central Apennines (Mount Velino, Abruzzo region). The nomenclatural type of Brachypodenion genuensis (Koelerio splendentisBrometum erecti) is also located in the central Apennines (Gran Sasso massif), being less than 50 $\mathrm{km}$ distant from Saturejo-Brometum. Saturejo-Brometum, Koelerio-Brometum are floristically, ecologically and coenologically very similar to each other, and it would be at the very least peculiar if they did not share the same suballiance. Since $\mathrm{Si}$ deritidenion italicae and Brachypodenion genuensis were described in the same paper it is necessary to choose one of these names as reference name for the suballiance. This name is here designated as Sideritidenion italicae Biondi, Ballelli, Allegrezza \& Zuccarello 1995. Lavandulo-Asphodelinetum luteae (type-association of Cytiso-Bromion) is also included in Sideritidenion italicae. As a consequence Sideritidenion italicae Biondi et al. 1995 is to be considered the type-suballiance of the alliance Cytiso spinescentis-Bromion erecti Bonin 1978. This suballiance includes all the associatons developed on the montane belt of the central and southern Apennines on limestone substrate and has its nomenclatural type in the association $\mathrm{Sa}$ turejo montanae-Brometum erecti Avena \& Blasi ex Biondi et al. 1995 (the type-relevè floristically updated to Conti et al. 2005 is reported in Appendix 5). The choice of Saturejo-Brometum as association-type of Sideritidenion italicae leads this suballiance to be centered in the central Apennines, while the presence of a high number of dry grassland species widespread throughout the entire central-southern Apennines (e.g. Sesleria nitida, Stipa dasyvaginata, Carex macrolepis, Sideritis italica, Pimpinella tragium, Crepis lacera, Globularia meridionalis, Lomelosia crenata subsp. crenata, Onobrichis alba subsp. alba, Euphorbia myrsinites, Helianthemum oelandicum subsp. incanum, Cytisus spinescens, Ranunculus illyricus, Cerastium tomentosum, Carex kitaibeliana) justifies its widening to the southern Apennines². Nevertheless, the southern Apennines also host a group of dry grassland species which have an Italian distribution restricted to this area (e.g. Crepis rubra, Orchis collina, Orchys quadripunctata, Armeria macropoda, Seseli peucedanoides, Onobrychis alba subsp. pentelica, Viola aethnensis subsp. splendida, Achillea lucana, Sesleria calabrica, Festuca jeanpertii subsp. campana, Thymus thracicus, Ptilostemon stellatus), or which are known also, as sporadics, for the central Apennines (e.g. Ophrys lacaitae, Ophrys lutea, Asphodeline liburnica, Viola pseudogracilis) which, although often showing a scattered presence in phytosociological and/or synoptic tables, could leave open the possibilities for alternative syntaxonomical schemes, such as the definition of an endemic suballiance only for southern Italy (in fact Art. 28a of ICPN would provide for the description of a new suballiance, named Cytiso spinescentis-Bromenion erecti, containing the nomenclatural type of the alliance).

Owing to the mountainous distribution of the suballiance Sideritidenion italicae, a different suballiance is required to include the dry grassland communities of the hilly and submontane belts of Peninsular Italy. Biondi et al. (2005) proposed (invalidly) the suballiance Phleo ambiguiBromenion erecti selecting Silene otites, Hieracium piloselloides, Stachys recta, Leontodon villarsii and Reichardia picroides as characteristic species. In our opinion this group of species does not have any particular biogeographical and/or ecological differential role. Actually, the only real difference between Phleo-Bromenion and Sideritidenion italicae would seem to be that in the former some common dry grasslands species which do not extend their distribution area to the upper part of the Marches Apennine are absent (e.g. Sideritis italica, Euphorbia myrsinites, Pimpinella lithophila, Cytisus spinescens, Hypochoeris cretensis), whereas a few others (Sesleria apennina, S. pichiana, $S$. italica) which could be considered somewhat N-C-Apennines endemics (see Trombetta et al. 2005; Foggi et al. 2006; Di Pietro 2007) are sporadically present. In a certain sense Phleo-Bromenion behaves as a sort of impoverished variant of Sideritidenion italicae (also geographically, if

\footnotetext{
${ }^{2}$ Very few are those dry grassland species which characterise the hilly and montane belt of the central Apennines and which do not occur also in the southern Apennines. Among these taxa, those belonging to the Centaurea ambigua s.l. and Centaurea rupestris s.l. collective groups are probably the most relevant.
} 
the syn-distribution areas of these two alliances - N-Marches Apennine vs. C-S Apennines - is compared). With the double aim of maintaining (partially) the proposal of Biondi et al. 2005 on the one hand, and to avoid the proliferation of new names on the other hand, the suballiance Phleo ambigui-Bromenion erecti Biondi, Allegrezza \& Zuccarello ex Di Pietro suball. nov. is here re-proposed hoc loco. The association Asperulo purpureae-Brometum erecti proposed invalidly in Biondi \& Ballelli (1981) is reproposed here as a new association and it is designated as holotypus of the new suballiance Phleo-Bromenion Biondi, Allegrezza \& Zuccarello ex Di Pietro suball. nov. The holotypus of Asperulo purpureae-Brometum erecti Biondi \& Ballelli ex Di Pietro ass. nov. is designated hoc loco in rel. 21 of Table 3 in Ballelli $\&$ Biondi (1982). The new group of characteristic species of Asperulo purpureae-Brometum erecti is composed of the following taxa: Asperula purpurea, Erisymum pseudorhaeticum, Coronilla minima, Stachys recta subsp. recta, Artemisia alba, Dianthus ciliatus. The floristically updated version of the type-relevé of Asperulo purpureae-Brometum erecti is reported in Appendix 5. The definition of a new type-relevé for Asperulo-Brometum underlines the thermophilous character of this association, enabling it to be more clearly distinguishable from similar associations occurring in the submontane and lower montane belt of the Umbrian-Marches Apennines, such as Potentillo cinereae-Brometum, Trigonello-Sideridetum (etc.). In particular, the differences between Asperulo-Brometum and Trigonello-Sideridetum appear to be more evident, and this allows a syntaxonomical separation to be hypothesised. The suballiance Phleo ambigui-Bromenion erecti includes the dry grassland communities, which are developed within the hilly and the submontane belts of the central and southern Apennines and which are strongly characterised by a Mediterranean floristic component. It should be noted that, in contrast to the montane suballiance Sideritidenion italicae, which is characterised by a high number of endemic species such as Avenula praetutiana, Brachypodium genuense, Centaurea ambigua, Rhinanthus wettsteinii, Dianthus brachycalyx, Senecio tenorei, (etc.) and by the transgressive supply of some other endemic species of Cytiso-Bromion (Sesleria nitida, Carex macrolepis, Stipa dasyvaginata subsp. appenninicola), the hilly suballiance Phleo-Bromenion does not possess an endemic component of its own. Nevertheless, the presence of a high Mediterranean therophitic component and the lack of ingressive species from the upper montane and subalpine belts of the Apennines, allow Phleo-Bromenion to be clearly distinguished both from Sideritidenion italicae and from the thermophilous aspects of central-European Xerobromion. As a consequence, in addition to the characteristic species for PhleoBromenion, a group of differential species drawn from Lygeo-Stipetea, Tuberarietea guttatae and Cisto-Micromerietea, has been selected with the role of ingressives (Figure 12 reports the map of distribution of Cytiso-Bromion suballiances in Peninsular Italy).

Applying this syntaxonomical framework to the specific case of the Aurunci mountains it can

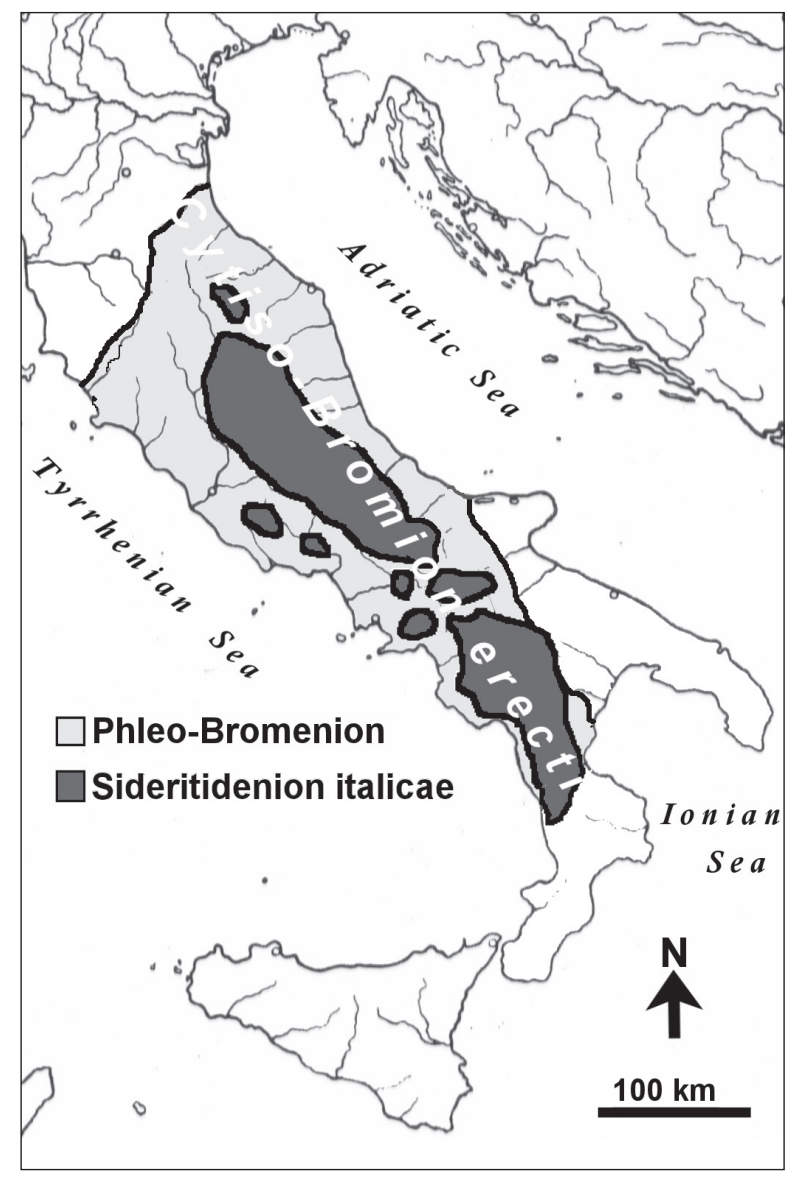

Figure 12: Distribution area of the two suballiances of CytisoBromion erecti (To note that inside the Sideritidenion italicae boundaries drawn on this map also the Phleo-Bromenion communities which are developed within the hilly belt of the main mountainous massifs are included).

Slika 12: Razširjenost dveh podzvez zveze Cytiso-Bromion erecti (znotraj mej podzveze Sideritidenion italicae prikazanih na karti so vključene tudi združbe podzveze Phleo-Bromenion, ki jih najdemo $\mathrm{v}$ hribovitem pasu glavnega masiva). 
be hypothesised that the montane Violo-Koelerietum is to be included in Sideritidenion italicae suballiance, whereas the hilly-submontane thermophilous Helichryso-Brometum is to be included in Phleo-Bromenion. The presence (in both associations) of a group of relevés occurring in the upper submontane belt and having intermediate floristic features between the two suballiances is due to the fact that Violo-Koelerietum and Helichryso-Brometum are distributed along an altitudinal gradient, and as a consequence give rise to stands of unclear syntaxonomical assignment in the contact areas.

On the basis of Mucina et al. (2009), the alliance Cytiso-Bromion caprini sensu Biondi et al. 1995 (supposedly including Cytiso-Bromion erecti Bonin 1978) is to be included in Artemisio-Brometalia (an order which replaces the nomen dubium Brometalia erecti). Differently, Ubaldi (2011) includes Cytiso-Bromion erecti in the new order Asphodelino liburnicae-Bromion erecti (nom. inval. art. 2). However, through different papers published between 1997 and 2011, Ubaldi proposed several new orders in which he included the dry grasslands associations described for the central and southern Apennines (see syntaxonomical scheme). Among these orders there is FestucoSeslerietalia nitidae Ubaldi 2003, which, according to the author, includes only the calcicolous dry pastures of the central Apennines. The syn-distribution of Festuco-Seslerietalia nitidae, restricted to the central Apennines, makes it to cover just a minor part of the geographical range of Artemisio-Brometalia Ubaldi ex Mucina \& Dengler 2009. For this reason a new suborder, named Festuco circummediterraneae-Seslerienalia nitidae subord. nov. (= Festuco-Seslerietalia nitidae Ubaldi 2003 stat. nov. hoc loco) is proposed in the present paper ${ }^{3}$. This suborder exhibits the same distributional range as that of Cytiso-Bromion erecti, and, as a consequence, it shares with it the same specific characteristic component ${ }^{4}$. Likewise Cyt-

\footnotetext{
${ }^{3}$ On the basis of Recommendation $10 \mathrm{~B}$ and $10 \mathrm{C}$ of ICPN the specific epithet has been added to the first generic name (Festuca) of the new suborder. Since Ubaldi (2003) did not included any species of Festuca in the original characteristic component of Festuco-Seslerietalia nitidae, the taxon Festuca circummediterranea Patzke has been selected hoc loco for the new suborder Festuco (circummediterraneae)-Seslerienalia nitidae.

${ }^{4}$ The specific characteristic component of FestucoSeslerietalia as proposed in the original paper of Ubaldi (2003) as diagnostic for the central Apennines was composed of Trifolium montanum, Centaurea ambigua,
}

iso-Bromion also Festuco-Seslerienalia nitidae is distinguishable from the other (possible) sub-orders which are already known, or which are still to be defined for Artemisio-Brometalia, by the presence of a high number of both Apennine endemics and amphi-Adriatic species.

\section{D Similarities Between the TYRRHENIAN DRY GRASSLANDS AND W-BALKANS ONES}

According to Mucina et al. (2009) the two alliances, since they both have an Apennine distribution, Cytiso-Bromion (sub: Phleo-Bromion) and Artemisio-Saturejion, are included in the same order Artemisio-Brometalia, although they had previously usually been placed in separate classes (Festuco-Brometea and Rosmarinetea/Cisto-Micromerietea, respectively) (Allegrezza et al. 1997; Pirone \& Tammaro 1997; Biondi et al. 2005). The hypothesis of the one single order, which excludes (at least for the Apennines) the possibility of using different syntaxonomical classes to distinguish

Potentilla crantzii, Sedum rupestre, Astragalus sempervirens and Seseli viarum. Amongst these species, only Trifolium montanum subsp. rupestre was maintained in the characteristic component of Festuco-Seslerietalia in Ubaldi's subsequent revision (Ubaldi 2011), whereas several other species (defined without distinction characteristic/differential) were added (Cerastium arvense subsp. suffruticosum, Knautia purpurea subsp. calabrica, Cyanus triumfetti, Alyssum montanum, Primula veris, Carum flexuosum, Myosotis ramosissima, Bellis perennis, Stachys officinalis, Narcissus poeticus, Viola eugeniae, Rumex acetosella, Potentilla cinerea, Linum catharticum). Such a peculiar characteristic component, which groups species having such different chorological and ecological/coenological features, is probably related to the fact that the author included in the same order a mesophilous sub-acidophilous alliance (Filipendulo vulgaris-Bromion erecti) and a xerophilous strictly calcicolous one (Seslerio-Caricion macrolepidis). Nevertheless, neither a biogeographical Apennine identity nor ecological/coenological homogeneous information would seem to be distinguishable by analysing this pool of species. In would seem more reasonable to include the mesophilous alliance Filipendulo-Bromion in a different order than Festuco-Seslerietalia nitidae (and than Artemisio-Brometalia as well), being the xerophilous alliance Seslerio nitidae-Caricion (nom. type: Seslerio nitidaeBrometum erecti) the nomenclatural type of the order. The enlargement of the geographical range of the new sub-order Festuco-Seslerienalia, with the inclusion of the whole southern Apennines, leads this new range to be more or less completely overlapping that of the alliance Cytiso-Bromion erecti with the logical consequence of having a characteristic component shared by the alliance and the suborder. 
perennial dry grasslands rich in chamaephytes and montane micro-garrigue rich in hemicryptophytes, finds strong similarities with the syntaxonomical scheme proposed by several authors for the W-Balkans (Horvatić 1958a; 1958b; Horvatić 1973; Horvat et al. 1974; Horvatić 1975; Feoli-Chiapella \& Poldini 1993) where there is a single order Scorzoneretalia villosae (or ScorzoneroChrysopogonetalia) which includes both chamaephytic alliances (e.g. Saturejion subspicatae) and hemicryptophytic ones (e.g. Scorzonerion villosae). It is likely, and not by chance, that it is precisely the Dalmatian dry grasslands - of all those occurring outside the Italian boundaries which exhibit the highest degree of similarity to those of the Aurunci Mts. According to Horvat et al. (1974), the calcicolous and thermophilous dry grasslands of the western Dinarids are to be included in two major alliances: Saturejion subspicatae (Scorzoneretalia villosae) and Chrysopogono-Koelerion splendentis. According to Horvatić (1975), this latter alliance belonged to TheroBrachypodietea through the order Koeleretalia splendentis. This theory was not followed by subsequent authors, who included Koelerietalia splendentis in Festuco-Brometea (Royer 1991; Trinajstić 1992; Redžić 2010). Finally Terzi (2011), included Koelerietalia splendentis in Scorzonero-Chrysopogonetalia as a syntaxonomical synonym. Actually, it is not easy to trace an ecological-biogeographical boundary between Scorzonero-Chrysopogonetalia and Koeleretalia splendentis, as well as between these two orders themselves and Artemisio-Brometalia. In fact, there are several species (e.g. Koeleria splendens, Plantago holosteum, Carex humilis, Thymus longicaulis, Teucrium montanum, Inula hirta, Convolvulus cantabrica, Euphorbia spinosa, Satureja montana, Hippocrepis comosa, Asperula aristata etc.) which are considered "characteristic" of one or the other syntaxon, depending on the author who is taken as reference (Horvat et al. 1974; Horvatić 1975, Oberdorfer 1992; Royer 1991, Theurillat et al. 1995; Biondi et al. 1995; Poldini 1995; Mucina et al. 2009). Typical Scorzoneretalia villosae dry grasslands occur in Italy in the Friulian Carso, where they behave as the westernmost fringe of the Croatian and Slovenian steppe-like grasslands (Feoli-Chiapella \& Poldini, 1993; Poldini 1995). Physiognomically similar dry grasslands with Stipa austroitalica and Scorzonera villosa subsp. columnae as dominant species and Bromus erectus relegated to a secondary role were found in southeastern Italy (Apulia,
Basilicata and Molise regions) and were referred to Scorzonero-Chrysopogonetalia (Fanelli et al. 2001; Forte et al. 2005; Biondi \& Guerra 2008; Di Pietro \& Wagensommer 2008; Terzi et al. 2010). As far as the central Apennines are concerned, strong floristic and coenological similarities to the SE-European Scorzonero-Chrysopogonetalia grasslands were already found by previous authors. Bonin (1978) included the alliance CytisoBromion erecti in Scorzonero-Chrysopogonetalia, while Royer (1991), in his European synthesis of Festuco-Brometea, included the central Apennine dry grasslands in the order Brometalia erecti on the basis of a favourable floristic balance in the comparison Brometalia erecti vs. ScorzoneroChrysopogonetalia. Royer's scheme is partially followed in the present paper, where all the central Apennine dry grasslands and most of the southern Apennine ones are included in the order Artemisio-Brometalia erecti. Nevertheless, it is not possible to ignore the floristic similarities between the Aurunci Mountain Violo-Koelerietum and the Dalmatian Koelerio-Festucetum illyricae Horvatić 1963 corr Trinajstić 1993 (= Festuco-Koelerietum sensu Horvatić 1963), especially if we consider this latter in the form of subass. globularietosum cordifoliae (Trinajstić 1986; 1992). Violo-Koelerietum and Koelerio-Festucetum are similar not only as far as their floristic composition is concerned, but also in respect of the coenological mosaic in which they are included, as well as their syndynamical trends. Both Violo-Koelerietum and Koelerio-Festucetum globularietosum exhibit a spatial contact with Salvia officinalis garrigues and are dynamically related to Ostrya carpinifolia and Sesleria autumnalis woodlands (actually, the Koelerio-Festucetum ecological amplitude is significantly higher than that of Violo-Koelerietum, if it is true that Koelerio-Festucetum brachypodietosum retusi can be dynamically related to evergreen woods and shrubs such as Oleo-funiperetum phoeniceae, Querco-Pinetum halepensis and MyrtoQuercetum ilicis, as reported by Kamenjarin \& Pavletić (2003) for Čiovo island). However, both Violo-Koelerietum and Helichryso-Brometum lack species such as Festuca illyrica (according to Alegro \& Šoštarić (2006) the records of F. illyrica of the Dalmatian area are to be reported to F. rupicola or F. valesiaca), Festuca valesiaca, F. dalmatica, Koeleria macrantha, Centaurea tommasinii, C. spinoso-ciliata, Salvia bertolonii, Globularia cordifolia, Satureja cuneifolia, which are considered biogeographically and physiognomically diagnostic in 
Koelerio-Festucetum. In fact, the floristic context of the Aurunci mountains, and more in general of the whole Tyrrhenian district of central Italy, is clearly different from the context that currently exists in the Friulian Karst and Apulia. This is mainly due to the absence of some important diagnostic species. For example, Scorzonera villosa is absent, Chrysopogon gryllus is extremely rare, and amongst the Stipa pennata complex species solely Stipa dasyvaginata subsp. appenninicola occurs and always with the role of low-frequency companion. For this reason, the attractive hypothesis of using the same syntaxonomical reference (association) for grasslands communities in the western coastal side of both the Balkan and Italian peninsulas (as already happens for evergreen woodlands) is to be excluded (although the in-progress taxonomical revisions on the amphiadriatic groups of genus Festuca could change in part some previous syntaxonomical assumptions). It is somewhat strange, however, that associations which exhibit such floristic, coenological and syndynamical similarities could not share the same high-rank syntaxon. Therefore it will be necessary in the future to evaluate whether the degree of floristic autonomy between Scorzonero-Chrysopogonetalia and Artemisio-Brometalia throughout the Balkan-Apennine biogeographical province (sensu Rivas-Martínez et al. 2002) can be considered as sufficient to maintain these syntaxa as distinct, or, instead to hypothesize a single amphiadriatic order distinguishable both from the easternmost fringe of Scorzoneretalia villosae and from the central and western fringe of Artemisio-Brometalia erecti.

\section{CONCLUSIONS}

This phytosociological research has focussed on the dry grasslands of Ausoni-Aurunci mountains and has resulted in the establishment of two new associations for the Tyrrhenian side of Peninsular Italy: Violo-Koelerietum splendentis and HelichrysoBrometum erecti. The former occurs at altitudes from 900 to 1500 m and belongs mainly to the Fagus sylvatica dynamical series, while the latter occurs from 400 to $900 \mathrm{~m}$ and belongs to mesophilous Quercus ilex woods and Ostrya carpinifolia woods. The syntaxonomical and nomenclatural analysis of the dry grasslands of the whole of the central Apennines has led to significant changes to the old syntaxonomical schemes, which can be summarized as follows: the new suborder Festuco circummediterraneae-Seslerienalia nitidae is proposed; the invalid name Phleo ambigui-Bromion erecti Biondi et al. 1995 has been substituted with the valid name Cytiso spinescentis-Bromion erecti as representative of Peninsular Italy hilly, submontane and montane grasslands on limestone. This latter has been divided into two suballiances: Sideritidenion italicae (montane belt) and Phleo ambigui-Bromenion erecti (hilly and submontane belts). The syndistribution area of Cytiso spinescenti-Bromion erecti ranges from the northern Marches to northern Calabria (Pollino-Orsomarso mountains). Moving south Cytiso-Bromion is vicaried by Koelerio-Astragalion, which includes the montane dry grasslands and garrigues developed on siliceous substrates. The syntaxonomical framework, the nomenclatural types of alliance and suballiances and the list of characteristic species have been reported in the subparagraphs below. 


\section{SYNTAXONOMICAL SCHEME}

\section{(CL.) Festuco-Brometea Br.-Bl. \& Tüxen ex Br.-Bl. 1949}

(OR.) Artemisio albae-Brometalia erecti Ubaldi ex Mucina \& Dengler 2009

[Artemisio albae-Brometalia erecti (Biondi, Ballelli, Allegrezza \& Zuccarello 1995) Ubaldi 1997 nom. inval. Art. 5; Artemisio albae-Brometalia erecti (Biondi, Ballelli, Allegrezza \& Zuccarello 1995) Ubaldi 2003 nom. inval. Art. 5; Brometalia caprini Ubaldi 1997 nom. inval. Art. 5; Euphorbietalia myrsinitetis Ubaldi 2011 Synt. synon.; Asphodelino liburnicae-Brometalia erecti Ubaldi 2011 nom. inval. Art. 2. Seslerio nitidae-Caricion macrolepidis Ubaldi 1997 Synt. synon; Botriochloo ischaemoni-Bromion erecti Ubaldi 1997 Synt. synon. p.p. Violo pseudogracilis-Bromopsion caprinae Terzi 2011 Synt. synon. p.p.]

(s-OR.) Festuco circummediterraneae-Seslerienalia nitidae (Ubaldi 2003) stat. nov. hoc loco [Original form: Festuco-Seslerietalia nitidae Ubaldi 2003]

SubORDER TyPus: Seslerio nitidae-Caricion macrolepidis Ubaldi 1997 (Ubaldi, 2003: 247, 300)

(ALL.) Cytiso spinescentis-Bromion erecti Bonin 1978

[Original form: Cytiso-Bromion erecti Bonin 1978; Cytiso-Bromion caprini Barbero \& Bonin 1969 p.p. nom. inval. Art. 3; Crepido lacerae-Phleion ambigui Biondi \& Blasi 1982 nom. inval. Art. 3, 5; Phleo ambigui-Bromion erecti Biondi, Ballelli, Allegrezza \& Zuccarello 1995: nom. inval. Art. 2, 5; Seslerio nitidae-Caricion macrolepidis Ubaldi 1997 Synt. synon; Botriochloo ischaemoni-Bromion erecti Ubaldi 1997 Synt. synon. p.p.; Siderition italicae Ubaldi 2011 Synt. synon.; Knautio calycinae-Bromion caprini Ubaldi 2011 Synt. synon.; Violo pseudogracilis-Bromopsion caprinae Terzi 2011 Synt. synon. p.p.]

Alliance typus: Lavandulo angustifoliae-Asphodelinetum luteae Bonin 1978

(suball.) Sideritidenion italicae Biondi, Ballelli, Allegrezza \& Zuccarello 1995 corr. Biondi, Allegrezza, Zuccarello 2005

[Original form: Sideridenion syriacae Biondi, Ballelli, Allegrezza \& Zuccarello 1995. Seslerio-Xerobromion apenninum Bruno \& Covarelli 1968 nom. illeg. Art. 34; Brachypodenion genuensis Biondi, Ballelli, Allegrezza \& Zuccarello 1995: Synt. synon.)]

SUbAlliance typus: Saturejo montanae-Brometum erecti Avena \& Blasi ex Biondi, Ballelli, Allegrezza \& Zuccarello 1995

- Lavandulo angustifoliae-Asphodelinetum luteae Bonin 1978

- Saturejo montanae-Brometum erecti Avena \& Blasi ex Biondi, Ballelli, Allegrezza \& Zuccarello 1995

- Violo pseudogracilis-Koelerietum splendentis ass. nov.

(suball.) Phleo ambigui-Bromenion erecti Biondi, Allegrezza \& Zuccarello 1995 ex Di Pietro suball.nov.

[Phleo ambigui-Bromenion erecti Biondi, Allegrezza \& Zuccarello 2005 (nom. inval. Art. 3, 5).]

SubALliance typus: Asperulo purpureae-Brometum erecti Biondi \& Ballelli ex Di Pietro ass. nov.

- Asperulo purpureae-Brometum erecti Biondi \& Ballelli ex Di Pietro ass. nov.

- Helichryso italici-Brometum erecti ass. nov.

[incl. Saturejo montanae-Brometum erecti Avena \& Blasi 1979 medicaginetosum Lucchese et al. 1995 nom. inval. Art. 4; Saturejo montanae-Brometum erecti Avena \& Blasi 1979 leontodontetosum Lucchese et al. 1995 nom. inval. Art. 4 p.p.]

\section{(Cl.) Rumici-Astragaletea siculi Pignatti \& Nimis in Pignatti E., Pignatti S., Nimis \& $\underline{\text { Avanzini } 1980}$}

(s-OR.) Anthemidetalia calabricae Brullo, Scelsi \& Spampinato 2001

(ALl.) Koelerio brutiae-Astragalion calabrici Giacomini \& Gentile ex Brullo, in Brullo, Cormaci, Giusso del Galdo, Guarino, Minissale, Siracusa, Spampinato 2005.

[Koelerio-Astragalion calabri Giacomini \& Gentile 1961 nom. inval. Art. 8; Koelerio-Astragalion calabri Giacomini \& Gentile 1966 nom. inval. Art. 8; Koelerio-Astragalion calabrici Giacomini \& Gentile ex Brullo, Gangale \& Uzunov 2004 nom. inval. Art. 5]

Alliance typus: Astragaletum calabrici Giacomini \& Gentile ex Bonin 1978 


\section{LIST OF THE CHARACTERISTIC SPECIES OF ORDER, SUBORDER, ALLIANCE, AND SUBALLIANCES}

\section{Artemisio albae-Brometalia erecti Ubaldi ex Mucina \& Dengler 2007}

Characteristic species (Provisional): Aethionema saxatile, Allium sphaerocephalon, Alyssum montanum, Anthericum liliago, Anthyllis vulneraria subsp. rubriflora, Anthyllis vulneraria subsp. weldeniana, Arabis collina, Arabis sagittata, Artemisia alba, Asperula aristata, Asperula purpurea, Asperula cynanchica, Astragalus monspessulanus, Biscutella laevigata, Brachypodium rupestre, Bunium bulbocastanum, Carlina acaulis subsp. caulescens, Cota tinctoria, Cyanus triumfetti, Dianthus sylvestris, Dorycnium penthaphyllum, Echinops ritro, Eryngium amethystinum, Festuca circummediterranea, Galium lucidum, Globularia bisnagarica, Helianthemum apenninum, Helianthemum nummularium subsp. obscurum, Hieracium piloselloides, Hippocrepis comosa, Inula hirta, Inula montana, Knautia purpurea, Koeleria cristata, Koeleria splendens, Koeleria vallesiana, Leontodon crispus, Linum tenuifolium, Melica ciliata, Muscari neglectum, Narcissus poeticus, Ononis spinosa, Ophrys apifera, Ophrys holoserica, Orchis antropophora, Orchis tridentata, Petrorhagia prolifera, Plantago sempervirens, Polygala major, Polygala nicaeensis (subsp. pl.), Potentilla hirta, Potentilla tabernaemontani, Pseudolysimachion barrelieri, Satureja montana, Scabiosa columbaria, Seseli montanum, Silene otites, Stachys recta (subsp. pl.), Teucrium chamaedrys, Teucrium montanum, Thesium humifusum, Trinia glauca.

\section{Festuco circummediterraneae-Seslerienalia nitidae (Ubaldi 2003) stat. nov.}

Characteristic species: (the same as for the alliance Cytiso-Bromion erecti)

\section{Cytiso spinescentis-Bromion erecti Bonin 1978}

Characteristic species: Asphodeline lutea, Carex macrolepis, Centaurea ambigua, Centaurea deusta subsp. deusta, Centaurea rupestris subsp. ceratophylla, Crepis lacera, Elaeoselinum asclepium, Erysimum pseudorhaeticum, Festuca inops, Hypochoeris cretensis, Laserpitium siler subsp. siculum, Phleum hirsutum subsp. ambiguum, Polygala flavescens, Potentilla detommasii, Stipa dasyvaginata subsp. apenninicola, Sideritis italica, Leontodon cichoraceous, Thymus striatus, Scabiosa holosericea, Sesleria nitida.
Regional Characteristic species: Alyssum diffusum, Argyrolobium zanonii, Euphorbia myrsinites, Helianthemum apenninum, Minuartia verna subsp. collina, Orchis pauciflora, Pimpinella tragium, Potentilla pedata, Ranunculus monspeliacus, Ranunculus illyricus, Ruta graveolens, Seseli palasii, Thlaspi praecox, Tragopogon samaritani.

Partial Charagteristic species ("S": Restricted to southern and eventually central Apennines; "N": Restricted to central/northern Apennines). Armeria macropoda (S), Asphodeline liburnica (S), Ophrys tenthredinifera (S), Ophrys lacaitae (S) Ophrys lutea (S), Orchis quadripunctata (S), Ornithogalum etruscum, Ornithogalum exscapum, Trifolium brutium (S), Festuca robustifolia (N), Sesleria apennina (N), Festuca stricta subsp. sulcata $(\mathrm{N})$.

Transgressive species: $(\mathrm{CM} / \mathrm{R}=$ shared with Cisto-Micromerietea/Rosmarinetea): Aethionema saxatile, Asperula aristata, Festuca stricta subsp. trachyphylla, Galium corrudifolium, Globularia bisnagarica, Plantago holosteum, Ranunculus millefoliatus, Insgressive species: Cytisus spinescens (CM/R), Euphorbia spinosa (CM/R), Onosma echioides (CM/R)

\section{Sideritidenion italicae (Biondi, Ballelli, Allegrezza \& Zuccarello 1995) Biondi, Allegrezza \& Zuccarello 2005}

Characteristic species: Acinos alpinus subsp. meridionalis, Anthemis cretica subsp. columnae, Avenula praetutiana, Brachypodium genuense, Dianthus brachycalyx, Onobrychis alba subsp. alba, Potentilla rigoana, Rhinanthus wettsteinii, Senecio tenorei, Silene notarisii, Trinia dalechampii, Veronica orsiniana.

REgional CHARAGTERISTIC SPECIES: Allium flavum, Carex humilis, Plantago argentea subsp. argentea, Potentilla incana, Gymnadenia conopsea, Acinos alpinus subsp. meridionalis, Valeriana tuberosa, Armeria canescens s.l.

Partial Characteristic species: Viola pseudogracilis

Transgressive species: Sesleria nitida, Carex macrolepis, Cerastium arvense subsp. suffruticosum, .

INGRESSIVE SPECIES: Lomelosia crenata subsp. crenata (GM/R), Helianthemum oelandicum subsp. incanum (CM/R), Globularia meridionalis $(\mathrm{CM} / \mathrm{R}),+$ species from Seslerion apenninae, Seslerietalia tenuifoliae, Elyno-Seslerietea (Anthyllis montana subsp. jaquinii, Cerastium tomentosum, Edrajanthus graminifolius, Festuca laevigata 
(ssp. pl)., Sesleria juncifolia, Paronichya kapela, Draba aizoides, Thymus praecox subsp. polytrichus, etc.).

\section{Phleo ambigui-Bromenion erecti Biondi,} Allegrezza \& Zuccarello ex Di Pietro suball. nov.

Characteristic species: Allium tenuiflorum, $C a$ rex flacca subsp. serrulata, Centaurium erythraea, Cephalaria leucantha, Convolvulus cantabrica, Coronilla minima, Crepis neglecta, Crupina vulgaris, Dianthus ciliatus, Hieracium cymosum, Linum bienne, Marrubium incanum, Melica transsylvanica, Melica ciliata, Muscari comosum, Ononis pusilla, Silene gallica, Silene paradoxa, Trifolium strictum.

REGIONAL CHARAGTERISTIC SPECIES: (most of the characteristic species).

Partial Characteristic species: Klasea flavescens, Lomelosia crenata subsp. pseudisetensis.

TRANSGRESSIVE SPECIES: Eryngium campestre, Elaeoselinum asclepium, Erysimum pseudorhaeticum.

INGRESSIVE SPECIES: Helichrysum italicum (CM/ $\mathrm{R})$, Teucrium capitatum (CM/R), Micromeria graeca $(\mathrm{CM} / \mathrm{R}),+$ species from Lygeo-Stipetea and Trachynetalia distachyae (Avena barbata, Briza maxima, Brachypodium retusum, Bupleurum baldense, Cynosurus echinatus, Linum strictum (ssp. pl.), Medicago minima, Ononis reclinata, Petrorhagia saxifraga, Reichardia picroides, Sideritis romana Trigonella gladiata, Trigonella monspeliaca, Triticum ovatum, Urospermum $d a$ lechampii)

\section{ACKNOWLEDGEMENTS}

This paper is dedicated to Giovanna Abbate, Marina Allegrezza, Giancarlo Avena, Sandro Ballelli, Edoardo Biondi, Carlo Blasi, Gilles Bonin, Franco Bruno, Francesco Corbetta, Krunica Hruska and Gianfranco Pirone, whose pioneering studies shed the first light upon the floristic and coenological originality of the central Apennines dry grasslands. Thanks also to the younger phytosociologists who subsequently contributed to enlarging the phytosociological knowledge of this peculiar environment. Sincere thanks are given to Jean-Paul Theurillat, for his precious help in sorting out the intricate nomenclatural questions, and to Massimo Terzi for the preliminary revision of the manuscript. Thanks also to the anonymous reviewers for their useful suggestions and comments. The present research was partially supported by a financial (and logistical) contribution from Monti Aurunci Regional Park. The present research was partially suported by a financial (and logistical) contribution from Monti Aurunci Regional Park, where a special mention is dedicated to all the members of the Parkguards corp.

\section{REFERENCES}

Abbate, G. \& Avena, G.C., Blasi, C. \& Fascetti, S. 1984: Pastures with Bromus erectus Hudson at the Mula, Muletta and Cozzo del Pellegrino Mountains (Western Calabria - Southern Italy). Annali di Botanica (Roma) 42: 67-74.

Alegro, A. \& Šoštarić, R. 2006: Morphometric characteristics within Festuca valesiaca agg. (Poaceae -Poeae) in Istria and the status of the F. illyrica Markgr.-Dann. Phyton (Horn) 46: 113-28.

Allegrezza, M. 2003: Vegetazione e paesaggio vegetale della dorsale del Monte San Vicino (Appennino centrale). Fitosociologia 40(1) Suppl. 1: 3-118.

Allegrezza, M., Biondi, E., Formica, E. \& Ballelli, S. 1997: La vegetazione dei settori rupestri calcarei dell'Italia centrale. Fitosociologia 32: 91-120.

Angiolini, C., Riccucci, C. \& De Dominicis, V.: 2003. Grasslands of the order Brometalia erecti Br.-Bl. 1936 on Antiapennine calcareous massifs in central-southern Tuscany (central Italy). Lazaroa 24: 61-85.

Avena, G. C. \& Blasi, C. 1979: Saturejo montanaeBrometum erecti ass. nova dei settori pedemontani dell'Appennino calcareo centrale. Archivio Botanico e Biogeografico Italiano 55: 34-43.

Avena, G. C., \& Blasi, C. 1980: Carta della vegetazione del Massiccio del Monte Velino. Appennino Abruzzese, P.F. "Promozione della qualità dell'ambiente", C.N.R., Roma, AQ/1/35: 1-18.

Avena, G. C. \& Bruno, F. 1975: Lineamenti della vegetazione del massiccio del Pollino, Appennino calabro-lucano. Notiziario Fitosociologico 10: 131-153.

Ballelli, S. \& Biondi, E. 1982: Carta della vegetazione del Foglio Pergola, 1:50.000. P.F. "Promozione della qualità dell'ambiente", C.N.R., Roma, AQ/1/86: 1-33. 
Ballelli, S., Biondi, E., Cortini-Pedrotti, C., Dell' Uomo, A., Francalancia, C., Hruska Dell'Uomo, K., Orsomando, E., Paganelli, A., Pedrotti, F. \& Sensi, M. 1977: Escursione sociale sull'Appennino Umbro-Marchigiano, Camerino 4-7 luglio 1977. Informatore Botanico Italiano 9 (3): 217-241.

Barberis, G., Bechi, N. \& Miceli P. 1995: Indagini biosistematiche e tassonomiche sul gruppo di Cerastium scaranii sensu Buschmann (Caryophyllaceae): problematiche relative. Bollettino della Società Sarda di Scienze Naturali 30: 517-529.

Barbero, M. \& Bonin, G. 1969: Signification biogéographique et phytosociologique des pelouses écorchées des massifs méditerranéens nord-occidentaux, des Apennins et des Balkans septentrionaux (Festuco-Seslerietea). Bulletin de la Société Botanique de France 116: 227-246.

Bechi, N. 1998: Ricerche citogeografiche in Cerastium arvense L. s.l. (Caryophyllaceae) in Italia. Webbia 53 (1): 1-12.

Biondi, E., 1988: Paturages et dynamisme de la vegetation dans l'apennin centro-septentrional. Colloques Phytosociologiques 16: 293-306.

Biondi, E., Allegrezza, M., Ballelli, S., Calandra, R., Crescente, M. F., Frattaroli, A. R., Gratani, L., Rossi, A., Taffetani, F. 1992: Indagini per una cartografia fitoecologica dell'altipiano di Campo Imperatore (Gran Sasso d'Italia). Bollettino dell'Associazione Italiana di Cartografia 86: 85-98.

Biondi, E., Allegrezza, M. \& Frattaroli A. R. 1992: Inquadramento fitosociologico di alcune formazioni pascolive dell'Appennino AbruzzeseMolisano. Documents Phytosociologiques N.S. 14: 195-210.

Biondi, E., Allegrezza, M. \& Zuccarello, V. 2005: Syntaxonomic revision of the Apennine grasslands belonging to Brometalia erecti, and an analysis of their relationships with the xerophilous vegetation of Rosmarinetea officinalis (Italy). Phytocoenologia 35 (1): 129-164.

Biondi, E. \& Ballelli, S., 1981: Su una nuova associazione di pascolo arido nell'Appennino centrale. Congresso Nazionale Società Botanica Italiana, Camerino, 26-29 ottobre 1981: 18.

Biondi, E., Ballelli, S. 1982: La vegetation du Massif du Catria (Apennin central) avec carte phytosociologique 1: 15.000. In: Pedrotti, F. (ed.): Guide-Itinéraire - Excursion Internationale de Phytosociologie en Italie centrale: 211-236.
Biondi, E. \& Ballelli, S. 1995: Le praterie del Monte Coscerno e Monte di Civitella (Appennino Umbro-Marchigiano - Italia centrale). Fitosociologia 30: 91-121.

Biondi, E., Ballelli, S., Allegrezza, M. \& Zuccarello, V. 1995: La vegetazione dell'ordine Brometalia erecti Br.-Bl. 1936 nell'Appennino (Italia). Fitosociologia 30: 3-45.

Biondi, E., Ballelli, S., Allegrezza, M., Guitian, J. \& Taffetani, F., 1986. Centaureo bracteataeBrometum erecti ass. nova dei settori marnosoarenacei dell'Appennino centrale. Documents Phytosociologiques N.S. 10 (2): 117-126. Camerino.

Biondi, E., Ballelli, S., Allegrezza, M., Taffetani, F., Frattaroli, A. R., Guitan J., Zuccarello V., 1999: La vegetazione di Campo Imperatore (Gran Sasso d'Italia). Braun-Blanquetia 16: 33-53.

Biondi, E. \& Blasi C. 1982: Crepido lacerae-Phleion ambigui nouvelle alliance pour les paturages arides a Bromus erectus de l'Apennin calcaire central et meridional. Documents Phytosociologiques 7: 435-442. Camerino.

Biondi, E. \& Blasi, C. 1984: Les pelouses seches calcaires a Bromus erectus de l'Apennin central et meridional (Italie). Colloques Phytosociologiques 11: 195-200.

Biondi, E., Blasi, C., Burrascano, S., Casavecchia, S., Copiz, R., Del Vico, E., Galdenzi, D., Gigante, D., Lasen, C., Spampinato, G., Venanzoni, R. \& Zivkovic, L. 2009: Manuale Italiano di interpretazione degli habitat della Direttiva 92/43/CEE. Società Botanica Italiana. Ministero dell'Ambiente e della tutela del territorio e del mare, D.P.N.

Biondi, E. \& Guerra, V. 2008: Vegetazione e paesaggio vegetale delle gravine dell'arco jonico. Fitosociologia 45 (1) Suppl. 1: 57-125.

Biondi, E., Guitian, J., Allegrezza, M. \& Ballelli, S. 1988: Su alcuni pascoli a Sesleria apennina Ujhelyi nell'Appennino centrale. Documents Phytosociologiques N.S. 11: 417-422. Camerino.

Biondi, E., Pinzi, M. \& Gubellini, L. 2004: Vegetazione e paesaggio vegetale del Massiccio del Monte Cucco (Appennino centrale, Dorsale Umbro-Marchigiana). Fitosociologia 41(2): 1-81.

Blasi, C. 1993: Carta del Fitoclima del Lazio. Regionalizzazione e caratterizzazione climatica. Regione Lazio, Assessorato Agricoltura e Foreste, Caccia e Pesca, Usi civivi. Università La Sapienza, Dip.to Biologia Vegetale, Roma. 
Blasi, C. 2006: Il Fitoclima d'Italia. In: Blasi, C. (ed), Completamento delle Conoscenze Naturalistiche di base, GIS Natura. Direzione per la protezione della Natura, Ministero dell'Ambiente e della Tutela del Territorio.

Blasi, C., Boitani, L., La Posta, S., Manes, F. \& Marchetti, M. 2005. Biodiversity in Italy. Palombi Editore, Roma.

Blasi, C., Capotorti, G. \& Fortini, P. 1998: On the vegetation series in the northern sector of the Simbruini mountains (Central Apennines). Fitosociologia 35: 85-102.

Blasi, C., Di Pietro, R. \& Pelino, G. 2005: The vegetation and landscape of alpine belt karsttectonic basin in the Majella mountain (central Apennines). Plant Biosystems 139 (3): 357-385.

Blasi, C., Marignani, M., Copiz, R., Fipaldini, M. \& Del Vico, E. 2010. Le Aree Importanti per le piante nelle regioni d'Italia. Il presente e il futuro della conservazione del nostro patrimonio botanico. Progetto Artiser, Roma. 224 pp.

Blasi, C., Tilia, A. \& Abbate, G. 1990: Le praterie aride dei M.ti Ruffi (Lazio - Italia centrale). Annali Botanica (Roma) Studi sul Territorio 48 (7): 17-32.

Bonin, G. 1978: Contribution à la connaissance de la végétation des montagnes de l'Apennin centro-meridional. Thèse Univ. Marseille, Centre Regional de Documentation Pedagogique, Marseille, France. 318 pp.

Braun-Blanquet, J. 1964: Pflanzensoziologie. Grundzüge der Vegetationskunde. Springer Verlag Wien: 865 pp.

Brullo, S., Cormaci, A., Giusso Del Galdo, G., Guarino, R., Minissale, P., Siracusa G. \& Spampinato, G. 2005. A syntaxonomical survey of the Sicilian dwarf shrub vegetation belonging to the class Rumici-Astragaletea siculi. Annali di Botanica (Roma) n.s. 5: 103-149.

Brullo, S., Gangale C. \& Uzunov, D. 2004: The orophilous cushion-like vegetation of the Sila. Massif (S Italy). Botanische Jahrbücher für Systematik, Pflanzengeschichte und Pflanzengeographie 125(4): 453-488.

Brullo, S., Giusso del Galdo, G.P. \& Minissale, P. 2009: Taxonomic revision of the Koeleria splendens C. Presl group (Poaceae) in Italy based on morphological characters. Plant Biosystems 143: 140-161.

Bruno, F. \& Covarelli, G. 1968: I pascoli e i pratipascoli della Valsorda (Appennino Umbro). Notiziario Fitosociologico 5: 47-64.
Castelli, M. 1995: Brometi del versante padano dell'Appennino Ligure-Piemontese (Italia). Fitosociologia 30: 51-90

Castelli, M., Biondi, E. \& Ballelli, S. 2001: La vegetazione erbacea, arbustiva e preforestale del piano montano dell'Appennino piemontese (Valli Borbera e Curone - Italia). Fitosociologia 38(1): 125-151.

Catorci, A., Gatti, R. \& Ballelli, S. 2007: Studio fitosociologico della vegetazione delle praterie montane dell'Appennino maceratese (Italia centrale). Braun-Blanquetia 42: 101-143.

Ciaschetti, G., Pirone, G., Frattaroli, A. R. \& Corbetta, F., 2006: La vegetazione del Piano di Pezza (Parco Naturale Regionale "Sirente-Velino", Italia Centrale). Fitosociologia 43 (1): 67-84.

Conti, F., Abbate, G., Alessandrini, A. \& Blasi, C. 2005: An Annotated Checklist of the Italian Vascular Flora. Palombi Editore, Roma.

Corbetta, F. 1984: Lineamenti vegetazionali dell'Appennino meridionale. Biogeographia N.S. 10: 141-159.

Corbetta, F., Ubaldi, D. \& Puppi, G. 1984: Tipologia fitosolciologica delle praterie altomontane del Monte Volturino e del Monte della Madonna di Viggiano (Appennino lucano). Biogeographia N.S. 10: 207-236.

Di Pietro, R. 2007: Taxonomical features of Sesleria calabrica stat. nov. (Poaceae), a neglected species from southern Italy. Folia Geobotanica 42: 289-313.

Di Pietro, R. \& Blasi, C., 2002: A phytosociological analysis of abandoned olive groves grasslands of Ausoni mountains (Tyrrhenian district of Central Italy). Lazaroa 23: 79-93.

Di Pietro, R., Pelino, G., Stanisci, A. \& Blasi C. 2008: Phytosociological Features of Adonis distorta and Trifolium noricum subsp. praetutianum, two endemics of the Apennines (Peninsular Italy). Acta Botanica Croatica 67(2): 175-200.

Di Pietro, R. \& Wagensommer, R. P. 2008: Analisi fitosociologica su alcune specie rare o minacciate del Parco Nazionale del Gargano (Italia centro-meridionale) e considerazioni sintassonomiche sulle comunità casmofitiche della $\mathrm{Pu}$ glia. Fitosociologia 45 (1): 177-200.

Fanelli, G., Lucchese, F. \& Paura B. 2001. Le praterie a Stipa austroitalica di due settori adriatici meridionali (basso Molise e Gargano). Fitosociologia 38(2): 25-36.

Feoli-Chiapella \& Poldini, L. 1993: Prati e pascoli del Friuli (NE Italia) su substrati basici. Studia Geobotanica 13: 3-140. 
Foggi, B., Rossi, G. \& Pignotti, L: 2007: Sesleria pichiana (Poaceae): a new species from NorthWest Italian peninsula. Webbia 62(1): 1-10

Forte, L., Perrino, E. V. \& Terzi, M., 2005: Le praterie a Stipa austroitalica Martinovsky ssp. austroitalica dell'Alta Murgia (Puglia) e della Murgia Materana (Basilicata). Fitosociologia 42 (2): 83-103.

Francalancia, C. \& Orsomando, E. 1981: Carta della vegetazione del Foglio Spoleto, 1980, 1:50.000. P.F. "Promozione della qualità dell'ambiente", G.N.R., Roma, AQ/1/87.

Frattaroli, A. R. 1988: La vegetazione della dolina "Fossa Raganesca" (Appennino centrale - Italia). Documents Phytosociologiques 11: 491-503.

Giacomini, V. \& Gentile, S. 1961: Observations synthétiques sur la végétation anthropogène montagnarde de la Calabre (Italie meridionale). Delpinoa 3: 55-67.

Giacomini, V. \& Gentile, S. 1966: Observations synthétiques sur la végétation anthropogène montagnarde de la Calabre (Italie meridionale). Anthropogene Vegetation: 135-145.

Horvat, I., Glavač, V. \& Ellenberg, H. 1974: Vegetation Sudosteuropas. Fischer Verlag. Stuttgart. $768 \mathrm{pp}$.

Horvatić, S. 1958a: Typologische gliederung der garrigues und kieferwälder-vegetation des ostradriatischen küstenlandes. Ebenda 17: 1-98.

Horvatić S. 1958b: Geographisch-typologische Gliederung der Niederungs-Wiesen und Weiden Kroatiens. Pflanzengeographischen Gebiete Kroatiens. Angewandte Pflanzensoziologie 15: 63-73.

Horvatić, S. 1973: Syntaxonomic analysis of the vegetation of dry grassland and stony meadows in Eastern Adriatic coastal Karst district based on the latest phytocoenological research. Fragmenta Herbologica Jugoslavica 32: 1-15.

Horvatić, S. 1975: Neuer Beitrag zur Kenntnis der Syntaxonomie der Trocken-Rasen und Steintriften-Gesellschaften des ostadriatischen Karstgebietes. In: Jordanov D., Bondev I., Kozuharov S., Kuzmanov B., Palamarev E. \& Velcev V. (ed.): Problems of Balkan Flora and Vegetation. Bulgarian Academy of Science, Sofia: 300-310.

Hruska-Dell'Uomo K. 1976: Contributo alla conoscenza dei pascoli aridi dell'Appennino marchigiano. Notiziario Fitosociologico 12: 19-30.
Hruska, K. 1982: Les paturages de Collelongo. In: Pedrotti F. (ed.): Guide-Itinéraire - Excursion Internationale de Phytosociologie en Italie centrale: $211-236$.

Kamenjarin, J. \& Pavletić, Z. 2003: Analiza vegetacije na otoku Čiovu. Hladnikia 15-16: 23-41.

Lucchese, F. \& Lattanzi, E. 2000: Atlante della flora dei Monti Ausoni. Regione Lazio. New Publ. House, Roma. 461 pp.

Lucchese, F., Persia, G. \& Pignatti, S. 1995: I prati a Bromus erectus Hudson dell'Appennino Laziale. Fitosociologia 30: 145-180.

Lucchese, F. \& Pignatti, S. 1990: Cynaro-Cichorietum pumili, un example de diversité floristique exceptionelle dans les environs de Rome (Italie). Ecologia Mediterranea 16:279-290.

Maiorca, G. \& Spampinato, G. 1999: La vegetazione della riserva naturale orientata "Valle del fiume Argentino" (Calabria nord-occidentale). Fitosociologia 36 (2): 15-60.

Miceli, P., Bechi, N. \& Barberis G. 1997: Biosystematic investigation on perennial Cerastium (Caryophyllaceae) populations from Tuscany (N-W Italy). Lagascalia 19 (1-2): 819-829.

Moraldo, B., Minutillo, F. \& Rossi, W. 1990: Flora del Lazio Meridionale. Quaderni dell'Accademia Nazionale dei Lincei 264: 219-292.

Mucina, L., Dengler, J., Bergmeier, E., Čarni, A., Dimopoulos, P., Jahn, R. \& Matevski, V. 2009: New and validated high-rank syntaxa from Europe. Lazaroa 30: 267-276 (2009).

Oberdorfer, E. 1992: Suddeutsche Pflanzengelleschaften. Teil 2: 86-180 Aufl. Gustav Fischer, Jena.

Peruzzi, L. Barbo, M. Bartolucci, F. Bovio, M. Carta, A. Ciccarelli, D. Conti, F., Costalonga, S. Di Pietro, R. Galasso, G. Gestri, G. Lattanzi, E. Lavezzo, P. Marsili, S. Peccenini, S. Pierini, B. Tardella, F.M. Terzo, V. Turrisi, R.E. \& Bedini G. 2009: Contributo alla conoscenza floristica delle Colline Pisane: resoconto dell'escursione del Gruppo di Floristica (S.B.I.) nel 2009. Informatore Botanico Italiano 43(1): 3-27.

Petriccione, B. 1993: Flora e vegetazione del Massiccio del Monte Velino. Ministero delle Risorse Agricole e Forestali, Collana verde 92: $261 \mathrm{pp}$.

Pignatti S. 1982: Flora d'Italia. Edagricole, Bologna.

Pignatti, S., Menegoni, P., Pietrosanti, S., 2005: Bioindicazione attraverso le piante vascolari. 
Valori di indicazione secondo Ellenberg (Zeigerwerte) per le specie delle Flora d'Italia. Braun-Blanquetia 39: 1-97.

Pirone G., Tammaro, F. 1997: The hilly calciophilous garigues in Abruzzo (central ApenninesItaly). Fitosociologia 32: 73-90.

Podani, J. 2001: SYN-TAX 2000. Computer Programs for Data Analysis in Ecology and Systematics. User's manual. Scientia Publishing, Budapest, Hungary.

Poldini, L. 1995: La classe Festuco-Brometea nell'Italia nordorientale. Fitosociologia 30: 47-50.

Poldini, L. \& Sburlino, G. 2005: Terminologia fitosociologica essenziale. Fitosociologia 42 (1): 57-69.

Quintanar, A., Glazkova, E. \& Castroviejo, S. 2009: On the identity and typification of Koeleria lobata (M. Bieb.) Roem. \& Schult. (Pooideae, Gramineae). Taxon 58 (2): 617-620.

Redžić, S. 2010: The origin, syndynamics and syntaxonomy of thermophilous vegetation of class Festuco-Brometea Br.-Bl. et R.Tx in Br.-Bl. 1943 at the Dinaric Alps (W. Balkan). 10th Symposium on the Flora of Southeastern Serbia and Neighbouring regions, Vlasina 17 to 20 June 2010. Abstract: 31

Rivas-Martínez, S., Penas, A., \& Diaz, T. 2002: Biogeographic Map of Europe. Serv. Publ. Universidad de Leon. Leon.

Royer, J. M. 1991: Synthèse eurosibérienne, phytosociologique et phytogéographique de la classe des Festuco-Brometea. Dissertationes Botanicae 178: 1-296.

Scoppola, A. \& Pelosi, M. 1995: I pascoli della Riserva Naturale di Monte Rufeno (Viterbo, Italia centrale). Fitosociologia 30: 123-144.

Tammaro, F., 1995: Lineamenti floristici e vegetazionali del Gran Sasso meridionale. Bollettino del Museo Civico di Storia Naturale di Verona 19: 1-256.

Terzi, M., 2011: Nomenclatural revision of the order Scorzonero-Chrysopogonetalia. Folia Geobotanica \& Phytotaxonomica, DOI 10.1007/ s12224-011-9100-2.

Terzi, M., Di Pietro, R., \& D’Amico, F.S. 2010: Analisi delle specie indicatrici applicata alle comunità a Stipa austroitalica Martinovsky e relative problematiche sin tassonomiche. Fitosociologia 47(1): 3-28.

Theurillat, J-P., Aeschimann, D., Küpfer, P., Spichiger, R. (1994) 1995: The higher vegetation units of the Alps. Colloques Phytosociologiques 23: 189-239.
Trinajstić, I. 1986: Grassland vegetation of the island of Unija (Adriatic sea, Yugoslavia). Poljoprivredna znanstvena smotra 74: 275-285.

Trinajstić, I. 1992: Sintaksonomska analiza pasnjacke zajednice Festuco-Koelerietum splendentis H-ic 1963. Acta Botanica Croatica 51: 103-112.

Trombetta, B., Granati, A., D’Amato, G., Sabina, R., Martelli, G. \& Di Pietro, R., 2005: Un approccio integrato (tassonomico, biosistematico e fitosociologico) allo studio del genere Sesleria Scop. nell'Appennino. Informatore Botanico Italiano 37(1): 58-59.

Tutin, T.G., Burges, N.A., Chater, A.O., Edmondon, J.R., Heywood, V.H., Moore, D.M., Valentine, D.H., Walters, S.M. \& Webb, D.A., 1993: Flora Europaea, I (2nd ed). Cambridge University Press, Cambridge.

Tutin, T.G., Heywood, V.H., Burges, N.A., Moore, D.M., Valentine, D.H., Walters, S.M. \& Webb, D.A., 1968-1980: Flora Europaea, IIV, Cambridge University Press, Cambridge.

van der Maarel, E. 1979: Trasformation of coverabundance values in phytosociology and its effects on community similarity. Vegetatio 39: 97-144.

Ubaldi, D. 1997: Geobotanica e Fitosociologia. Clueb, Bologna: 360 pp.

Ubaldi D. 2003: Flora, fitocenosi e ambiente. Elementi di Geobotanica e Fitosociologia. Clueb, Bologna: 334 pp.

Ubaldi D. 2011: Le vegetazioni erbacee e gli arbusteti italiani. Aracne, Roma (2008): 361 pp.

Venanzoni, R. \& Gigante, D. 1999: I pascoli sommitali di Monte Tezio (Perugia, Italia). Fitosociologia 36 (1): 157-174.

Weber, H.E., Moravec, J., \& Theurillat J. P. 2000: International Code of Phytosociological Nomenclature. $3^{\text {rd }}$. edition. Journal of Vegetation Science 11: 739-768. 


\section{APPENDIX 1 \\ Sporadic species}

\section{Phytosociological Table 1}

Rel. 3: Minuartia mediterranea + , Geranium columbinum +, Orlaya daucoides 1; Rel. 4: Romulea bulbocodium +; Rel. 5: Alyssum alyssoides +; Rel. 7: Ornithogalum exscapum +; Rel. 9: Acinos arvensis subsp. arvensis +; Rel. 10: Poa alpina subsp. alpina 1; Rel. 12: Rhamnus saxatilis subsp. infectoria +, Rel. 13: Hieracium racemosum +; Rel. 14: Medicago minima + , Trifolium angustifolium angustifolium + , Trifolium scabrum scabrum 1, Trifolium stellatum +, Vulpia ciliata 1, Aira caryophyllea + , Sedum sexangulare 1, Acer opalus subsp. obtusatum +, Gastridium ventricosum + , Potentilla micrantha + , Sedum dasyphyllum 1, Sherardia arvensis +, Trifolium arvense +; Rel. 19: Silene vulgaris subsp. vulgaris +; Rel. 22: Vulpia myuros +; Rel. 25: Cynosurus echinatus +.

\section{Phytosociological Table 2}

Rel. 1: Myosotis ramosissima +; Rel. 2: Acer monspessulanum + , Acer opalus subsp. obtusatum + , Biarum tenuifolium +; Rel. 3: Trifolium nigrescens 1, Arenaria leptoclados + , Crocus suaveolens + , Fragaria vesca + , Geranium rotundifolium +, Hypericum perfoliatum +, Hypochaeris glabra +, Veronica arvensis +; Rel. 4: Rosa agrestis +, Geranium sanguineum +; Rel. 5: Euphorbia characias 1; Rel. 6: Cornus mas +, Rosa deseglisei +, Hedypnois rhagadioloides +; Rel. 7: Carex distachya +; Rel. 8: Hypericum montanum +; Rel. 10: Bellis perennis + , Taraxacum fulvum + , Cerastium pumilum +, Cerastium arvense subsp. strictum 1; Rel. 12: Anthoxanthum odoratum + , Allium amethystinum +, Asphodelus albus subsp. delphinensis +, Centaurium pulchellum +; Rel. 13: Asparagus acutifolius +, Silene italica +; Rel. 17: Polygala monspeliaca; Rel. 18: Trifolium pratense +, Rosa spinosissima 1, Lathyrus sylvestris 1, Vulpia ligustica 1; Rel. 19: Pallenis spinosa +, Silene gallica +; Rel. 20: Trifolium striatum +, Erophila verna + , Pyrus pyraster + , Orlaya daucoides + , Trifolium infamia-ponertii + , Trigonella monspeliaca +; Rel. 21: Allium vineale +; Rel. 22: Daphne gnidium + , Phillyrea latifolia + , Linaria purpurea + , Pulicaria odora 1, Serapias vomeracea +; Rel. 23: Erica arborea 2, Iberis umbellata 1; Rel. 24: Clematis flammula +, Quercus cerris +, Ceterach officinarum +; Rel. 27: Centaurea calcitrapa 1, Crepis capillaris +.

\section{Synoptic Table 3}

COL. 1 - Helianthemum nummulatium subsp. glabrum: 1, Daphne oleoides: 1, Sorbus aria: 1, Cuscuta epithymum subsp. kotschyi: 1, Hieracium racemo- sum: 1 , Iris relicta: 1 , Orobanche gracilis: 1 , Potentilla micrantha: 1; COL. 2 - Calicotome villosa: 2, Carex distachya: 1, Euphorbia characias: 1, Acer monspessulanum: 1, Clematis vitalba: 2, Cornus mas: 1, Rosa agrestis: 1, Rosa deseglisei: 1, Anemone hortensis: 2, Biarum tenuifolium: 1, Crepis capillaris: 1, Crocus suaveolens: 1, Fragaria vesca: 1, Hedypnois rhagadioloides: 1, Hypericum montanum: 1, Hypericum perfoliatum: 1, Hypochaeris glabra: 1, Myosotis ramosissima: 1, Viola pseudogracilis subsp. cassinensis: 2; COL. 3 - Iberis umbellata: 1, Clematis flammula: 1, Daphne gnidium: 1, Pistacia lentiscus: 1, Erica arborea: 1, Pyrus pyraster: 1, Quercus cerris: 1, Allium amethystinum: 1, Biscutella didyma: 1, Centaurium pulchellum: 1, Gladiolus italicus: 1, Ophrys lacaitae: 1, Polygala monspeliaca: 1, Pulicaria odora: 1, Serapias vomeracea: 1, Silene gallica: 1, Trifolium infamia-ponertii: 1, Vulpia ligustica: 1; COL. 4 - Juniperus oxycedrus: 1, Ononis minutissima: 1; COL. 5 - Kengia serotina: 2, Thlaspi perfoliatum: 1; COL. 6 - Andryala integrifolia: 1, Armeria denticulata:1, Astragalus hamosus: 1, Bromus sterilis: 1, Carduus pycnocephalus: 1, Centaurea aplolepa: 1, Convolvulus arvensis: 1, Crepis vesicaria: 1, Crepis zacintha: 1, Echinops ritro subsp. siculus: 1, Echium italicum: 1, Hordeum leporinum: 1, Lactuca virosa: 1, Muscari comosum: 1, Orlaya grandiflora: 3, Orobanche caryophyllea: 1, Papaver rhoeas: 1, Petrorhagia velutina: 1, Santolina etrusca: 2, Scabiosa uniseta: 1, Sedum rubens: 1, Trifolium cherleri: 1, Trifolium ligusticum: 1, Verbascum lychnitis: 1, Vicia cracca: 1, Vicia disperma: 1, Vicia lutea: 1, Xeranthemum cylindraceum: 2; COL. 7 - Iberis saxatilis: 4, Tolpis staticifolia: 1; COL. 9 - Saxifraga granulata: 1, Klasea nudicaulis: 4, Senecio apenninus: 2, Tulipa australis: 2; COL. 10 - Marrubium vulgare: 2, Rumex acetosa: 1, Salvia sclarea: 1; COL. 11 - Allium paniculatum: 1, Bunium petraeum: 1, Corylus avellana: 1, Filago arvensis: 1, Helleborus foetidus: 2, Hieracium bifidum: 2, Funiperus alpina: 2, Pedicularis petiolaris: 1, Pimpinella anisoides: 1, Ranunculus garganicus: 1, Saxifraga granulata: 1, Sedum hispanicum: 1 , Trifolium squarrosum: 1 , Vincetoxicum hirundinaria: 1; COL. 13 - Bupleurum falcatum subsp. cernuum: 1, Cytisophyllon sessilifolius: 1, Primula veris: 1, Senecio doronicum: 2, Trifolium rubens: 1 , Vicia onobrychioides: 1, Vicia tenuifolia: 1;COL. 17 - Reseda lutea: 2; COL. 18 - Arenaria grandiflora: 1, Crepis pulchra: 2, Gnaphalium uliginosum: 3, Lactuca saligna: 1 , Orobanche alba: 1 , Polygala vulgaris: 1, Trifolium tomentosum: 3; COL. 19 - Allium carinatum: 1, Alyssum campestre: 2, Cerastium semidecandrum: 1, Myosotis arvensis subsp. arvensis: 1, Ophrys fuciflora: 2, Senecio provincialis:1; COL. 20 - Thy- 
mus oenipontanus: 1 , Thymus pannonicus: 1 , Ferulago campestris: 1, Inula spiraeifolia: 1, Stachys sylvatica: 1; COL. 25 - Osyris alba: 1, Teucrium flavum: 1; COL. 26 - Senecio doronicum: 3, Helianthemum nummularium subsp. grandiflorum: 3, Orlaya grandiflora: 2, Hypochaeris cretensis: 1, Solenanthus apenninus: 1, Allium carinatum: 1, Cytisus sessilifolius: 1, Potentilla calabra:1, Anchusa azurea: 1, Lamium maculatum: 1, Geranium robertianum: 1, Pinus leucodermis: 1, Sorbus aucuparia: 1.

\section{APPENDIX 2 \\ Place and date of the relevés}

\section{Phytosociological Table 1}

Rel. 1-2: M. Redentore, 16/06/2000, Rel. 3-5: M. Revole, 01/06/2010; Rel. 6-16, 19-20: M. Petrella, 18/06/1997; Rel. 7-8: M. Redentore, 23/06/1997; Rel. 9: M. Faggeto, 28/06/1997; Rel. 10-11, 22: M. Ruazzo, 27/06/1997; Rel. 12: M. Forte, 24/07/2002; Rel. 13: M. Altino, 02/07/1996; Rel. 14: M. Faggeto, 02/07/1996; Rel. 15: M. S. Angelo, Rel. 17-18: M. Redentore, 16/06/2000; Rel. 21: M. Redentore, 22/06/1997.

\section{Phytosociological Table 2}

Rel. 1-2: Serra Palombi (Monti Ausoni), 14/ 05/1997, Rel. 3: M. delle Fate (Monti Ausoni), 14/05/1997; Rel. 4: Forcella Buana (Monti Ausoni), 16/05/1997; Rel. 5: Limatella (Monti Ausoni), 16/05/1997; Rel. 6: M. Caruso (Monti Ausoni), 29/05/1997; Rel. 7: Valle Case Nuove (Monti Ausoni), 07/05/1997; Rel. 8-9-10: M. delle Fate (Monti Ausoni), 14/05/1997; Rel. 11: Polleca (M.ti Aurunci), 14/06/2010; Rel. 12: M. Maio (M.ti Aurunci orient.), 04/07/1997; Rel. 13: M. Fammera (M.ti Aurunci), 07/07/1996; Rel. 14-15-16: M. Fusco (M.ti Aurunci), 06/07/1996; Rel. 17: Monte Le Pezze (M.ti Aurunci), 24/06/1996; Rel. 18: Felitto-Acquaviva (M.ti Aurunci), 24/06/1996; Rel. 19: Sella tra M.te Le Pezze e M.te Cervello (M.ti Aurunci), 24/06/1996; Rel. 19: Sella tra M.te Le Pezze e M.te Cervello (M.ti Aurunci), 24/06/1996; Rel. 20: M.te Cervello (M.ti Aurunci), 24/06/1996; Rel. 21: M.te Trino (M.ti Aurunci), 24/06/1996; Rel. 22: Pendici M.te Le Pezze (M.ti Aurunci), 23/06/1996; Rel. 23: Santuario della Civita (M.ti Aurunci), 23/06/1996; Rel. 24: Forcella di Fammera (M.ti Aurunci), 03/07/1996; Rel. 25: Monte Doro (M.ti Aurunci), 21/07/1996; Rel. 26: Monte Fammera (M.ti Aurunci), 07/07/1996; Rel. 27: Monte Vele (M.ti Aurunci), 23/06/1996.

\section{APPENDIX 3}

\section{List of the syntaxa quoted in the text}

Artemisio albae-Brometalia erecti Ubaldi ex Mucina \& Dengler 2009; Artemisio albae-Satureion montanae Allegrezza, Biondi, Formica \& Ballelli 1997; Artemisio-Brometalia Ubaldi ex Dengler \& Mucina 2009; Asperulo purpureae-Brometum erecti Biondi \& Ballelli ex Biondi, Ballelli, Allegrezza \& Zuccarello 1995; Asperulo purpureae-Brometum erecti sideridetosum syriacae (Hruska, 1982) Biondi, Ballelli, Allegrezza \& Zuccarello 1995; Botriochloo-Bromion erecti Ubaldi 1997; Brometalia erecti Koch 1926; Cerastio-Carlinetea nebrodensis Brullo 1984; Chrysopogono-Koelerion splendentis Horvatić 1975; Cisto cretici-Micromerietea julianae Oberdorfer 1954; Cynosurion cristati Tüxen 1947; Euphorbietalia myrsinitides Ubaldi 2011; Festuco-Brometea Br.-Bl. \& Tüxen ex Br.-Bl. 1949; Festuco-Koelerietum Horvatić 1963; Festuco circummediterraneae-Seslerienalia nitidae (Ubaldi 2003) stat. nov. hoc loco; Festuco-Seslerietalia nitidae Ubaldi 2003; Filipendulo vulgaris-Bromion erecti Ubaldi 2011; Helichryso italici-Brometum erecti ass. nov.; Helichryso italici-Brometum erecti euphorbietosum spinosae subass. nov.; Koelerio-Astragalion calabrici Giacomini \& Gentile ex Bonin 1978; Koelerio-Astragalion calabrici Giacomini \& Gentile ex Brullo, Gangale \& Uzunov 2004 nom. inval.; Koelerio brutiae-Astragalion calabrici Giacomini \& Gentile ex Brullo, in Brullo, Cormaci, Giusso del Galdo, Guarino, Minissale, Siracusa, Spampinato 2005; Koeleretalia splendentis Horvatić 1975; Koelerio splendentis-Festucetum illyricae brachypodietosum retusi Trinajstić 1992; Knautio calycinae-Bromion caprini Ubaldi 2011; Koelerio splendentis-Festucetum illyricae globularietosum cordifoliae Trinajstić 1992; Koelerio-Festucetum illyricae Trinajstić 1992; Lavandulo angustifoliae-Asphodelinetum luteae Bonin 1978; Lonicero etruscae-Carpinetum orientalis Blasi, Di Pietro, Filesi \& Fortini 2001; Myrto-Quercetum ilicis, Horvatić ex Trinajstić 1983; Oleo-funiperetum phoeniceae, Arrigoni, Bruno, De Marco, Veri in De Marco, Dinelli, Caneva 1985; Ostryo-Quercetum ilicis Trinajstić (1965) 1974; Phleo ambiguiBromenion erecti Biondi, Allegrezza \& Zuccarello 2005; Phleo ambigui-Bromion erecti Biondi \& Blasi ex Biondi, Ballelli, Allegrezza \& Zuccarello 1995; Plantago holostei-Helianthemetum cani, (Biondi, Ballelli, Allegrezza, Frattaroli \& Taffetani 1992) Biondi \& Ballelli in Biondi, Ballelli, Allegrezza \& Zuccarello 1995; Querco-Pinetum halepensis Loisel 1971; Rosmarinetea officinalis Rivas-Martinez, Diaz, Prieto, Loidi \& Penas 1991; Rumici-Astragaletea 
siculi Pignatti \& Nimis in Pignatti, Pignatti Nimis \& Avanzini 1980; Saturejion subspicatae (Horvat 1974) Horvatić 1975; Saturejo montanae-Brometum erecti Avena \& Blasi 1979; Saturejo montanaeBrometum erecti leontodontetosum Lucchese, Persia \& Pignatti 1995; Saturejo montanae-Brometum erecti medicaginetosum minimae Lucchese, Persia \& Pignatti 1995; Scorzoneretalia villosae Horvatić 1973; Scorzonerion villosae Horvatić 1963; Scorzonero villosae-Chrysopogonetalia grilli Horvatić \& Horvat in Horvatić 1963; Seslerietalia tenuifoliae Horvat 1930; Sideritidenion italicae Biondi, Ballelli, Allegrezza \& Zuccarello 1995 corr. Biondi, Allegrezza \& Zuccarello; Siderition italicae (Biondi, Ballelli, Allegrezza \& Zuccarello 1995) Ubaldi 2011; TheroBrachypodietea Br.-Bl. ex O. Bolòs 1950 em. RivasMart.1978; Trigonello monspeliacae-Sideritidetum syriacae Hruska (1982); Violo pseudogracilis-Bromopsion caprinae Terzi 2011; Violo pseudogracilisKoelerietum splendentis ass. nov.; Xerobromion (Br.Bl. \& Moor 1938) Moravec et al. 1967.

\section{APPENDIX 4}

\section{List of the plant communities referred to the} columns of the synoptic table

- COL. 1: Violo pseudogracilis-Koelerietum splendentis ass. nov. (Aurunci Mts, southern Latium)

- COL. 2: Helichryso italici-Brometum erecti typicum subass. nov. (Aurunci Mts, southern Latium)

- COL. 3: Helichryso italici-Brometum erecti saturejetosum montani subass. nov. (Aurunci Mts, southern Latium)

- COL. 4: Saturejo montanae-Brometum erecti leontodontetosum Lucchese et al., 1995 (from Table 4 in Lucchese et al. 1995 Fitosociologia, 30); (Latium region mountains)

- COL. 5 Saturejo montanae-Brometum erecti medicaginetosum Lucchese et al. 1995 (from Table 4 in Lucchese et al., 1995, Fitosociologia, 30); (Latium region mountains)

- COL. 6: Cerastio etrusci-Brometum erecti Angiolini et al., 2003 (from Table 3 in Angiolini et al. 2003, Lazaroa, 24); (Tyrrhenian southern Tuscany mountains)

- COL. 7: Plantago holostei-Helianthemetum cani (Biondi et al., 1992) Biondi \& Ballelli 1995 (from Table 16 in Biondi et al. 1999, BraunBlanquetia, 16); (Campo Imperatore, Gran Sasso massif)
- COL. 8: Plantago holostei-Helianthemetum cani (Biondi et al., 1992) Biondi \& Ballelli 1995 (from COL. 33 in Biondi et al. 2005, Phytocoenologia, 35(1); (central Apennines)

- COL. 9: Plantago holostei-Helianthemetum cani (Biondi et al., 1992) Biondi \& Ballelli 1995 (from Table 3 in Biondi \& Ballelli 1995, Fitosociologia 30); (Umbrian-Marches Apennines)

- COL. 10: Saturejo montanae-Brometum erecti Avena \& Blasi 1979 (from Table 3 in Avena \& Blasi 1979, Arch Bot. Biogeogr. Ital., 55); (Mount Velino massif, Abruzzo)

- COL. 11: Onobrychido albae-Seslerietum nitidae Bonin 1978 (from Table 18 in Bonin 1978, Thèse Univ. Marseille; Mount Velino, Abruzzo Apennines).

- COL. 12: Asperulo purpureae-Brometum erecti Biondi \& Ballelli ex Biondi et al. 1995 (from COL. 8 in Biondi et al. 2005, Phytocoenologia, 35(1); (Umbrian-Marches Apennines)

- COL. 13: Asperulo purpureae-Brometum erecti Biondi \& Ballelli ex Biondi et al. 1995 (from Table 9 in Catorci et al. 2007, Braun-Blanquetia, 42); (Umbrian-Marches Apennines)

- COL. 14: Asperulo purpureae-Brometum erecti Biondi \& Ballelli ex Biondi et al. 1995 (from COL. 19 Table 2 in Biondi et al. 1995, Fitosociologia 30); (Umbrian-Marches Apennines)

- COL. 15: Asperulo purpureae-Brometum erecti teucrietosum montani Biondi \& Ballelli ex Biondi et al. 1995 (from COL. 20 Table 2 in Biondi et al. 1995, Fitosociologia 30); (UmbrianMarches Apennines)

- COL. 16: Asperulo purpureae-Brometum erecti sideridetosum syriacae (Hruska 1982) Biondi et al. 1995 (from COL. 22 Table 2 in Biondi et al. 1995, Fitosociologia 30); (Umbrian-Marches Apennines)

- COL. 17: Asperulo purpureae-Brometum erecti Biondi \& Ballelli ex Biondi et al. 1995 (from Table 3 in Ballelli \& Biondi 1982, CNR AQ/1/130); (Mount Catria, Marches)

- COL. 18: Trigonello monspeliacae-Sideridetum syriacae Hruska 1982 (From COL. 30 Table 1 in Hruska, 1982, Guide-Itineraire - Excursion Int. de Phytosoc. en Italie centrale); (Collelongo, Umbria)

- COL. 19: Potentillo cinereae-Brometum erecti Biondi et al. 2004 (from Table 10 in Catorci et al. 2007, Braun-Blanquetia, 42); (UmbrianMarches Apennines)

- COL. 20: Potentillo cinereae-Brometum erecti Biondi et al. 2004 (from Table 18 in Biondi et al. 
2004, Fitosociologia, 41(2) suppl. 1; (Mount Cucco, Umbrian-Marhes Apennines)

- COL. 21: Seselio viarum-Brometum erecti Biondi et al.1992 (from COL. 7 in Biondi et al. 2005, Phytocoenologia 35(1); (Abruzzo National Park)

- COL. 22: Koelerio splendentis-Brometum erecti Biondi et al.1992 (from COL. 1 in Biondi et al. 2005, Phytocoenologia 35(1); (Gran Sasso massif)

- COL. 23: Polygalo majoris-Brometum erecti Biondi et al.1995 (from COL. 3 in Biondi et al. 2005, Phytocoenologia 35(1); (Gran Sasso Massif)

- COL. 24: Seslerio nitidae-Brometum erecti Bruno in Bruno \& Covarelli 1968 (from COL. 5 in Biondi et al. 2005, Phytocoenologia 35(1); (Monte Catria, Marches Apennines)

- COL. 25: Fumano procumbentis-Stipetum appenninicolae Taffetani et al. 2004 (from Table 27 in Taffetani et al. 2004, Fitosociologia 41(2) suppl. 1; (I Cingoli range, Marches-Apennines).

- COL. 26: Lavandulo angustifoliae-Asphodelinetum luteae Bonin 1978 (from Table 21 in Bonin 1978, Thèse Univ. Marseille; Pollino range, southern Apennines).

\section{APPENDIX 5:}

Type relevé of Lavandulo angustifoliae-Asphodelinetum luteae Bonin 1978. Rel. 509 of Table 21 in: Bonin 1978. Site: Pollino range southern slopes, 1967. author: G. Bonin C. Altitude: 1570 m, Aspect: S, Slope 40\%, Cover 50\%, Area: $100 \mathrm{~m}^{2}$. List OF SPECIES: Lavandula angustifolia 1 , Asphodeline lutea 1, Leontodon crispus 1, Satureja montana + , Festuca circummediterranea 2, Sideritis italica 2, Centaurea deusta +, Cytisus spinescens 1, Phleum hirsutum subsp. ambiguum 1, Acinos alpinus 1, Polygala alpestris 1, Trifolium pratense 1, Thymus longicaulis + , Anthoxantum odoratum + , Allium carinatum + , Koeleria splendens 2 , Bromus erectus 2 , Festuca rubra +, Sanguisorba minor 1, Medicago lupulina 1, Lotus corniculatus 1, Anthyllis vulneraria subsp. rubriflora + , Senecio doronicum + , Poa alpina 1, Bunium bulbocastanum 1, Arabis collina + , Potentilla detommasii + , Linaria purpurea + , Solenanthus apenninus + , Scabiosa holosericea +

Type relevé of Saturejo montanae-Brometum erecti Avena \& Blasi ex Biondi, Ballelli, Alle- grezza \& Zuccarello 1995. Rel. 3 of Table 3 in: Avena \& Blasi 1979 (Arch. Bot. Biogeogr. Ital., 55). Site: Petrella Salto, 15.7.1972. Authors Avena G.C. \& Blasi C. Altitude: 1000 m., Aspect: S, Slope 20\%, Cover 45\%, Bedrock cover: $15 \%$, Area: $200 \mathrm{~m}^{2}$. List of SPECIES: Satureja montana 2, Sideritis italica 2, Plantago sempervirens 2, Cytisus spinescens 1, Globularia punctata +, Globularia meridionalis 1, Helianthemum oelandicum subsp. incanum 1, Cerastium tomentosum 1, Thymus pulegioides +, Euphorbia myrsinites 2, Bromus erectus 1, Sanguisorba minor subsp. balearica + , Carlina vulgaris subsp. vulgaris + , Allium sphaerocephalon + , Helianthemum apenninum 1, Alyssum alyssoides + , Teucrium chamaedrys +, Cerastium arvense subsp. arvense +, Armeria canescens +, Geranium pyrenaicum 1, Digitalis lutea subsp. australis + , Verbascum pulverulentum + , Cruciata laevipes +, Bunium bulbocastanum +, Erysimum pseudorhaeticum 1, Hornungia alpina +, Centaurea calcitrapa 1, Marrubium vulgare 1.

Type relevé of Astragaletum calabrici Giacomini \& Gentile ex Bonin 1978. Rel. 623 of Table 16 in: Bonin 1978 (in Bonin G. 1978. - Thèse Univ. Marseille 1-318.). Site: Sila Plateau, Fossiata, 1975. author: G. Bonin. Altitude: 1070 m., Aspect: N, Slope 35\%, Cover 60\%, Area: $100 \mathrm{~m}^{2}$. LIST OF SPECIES: Astragalus parnassi subsp. calabricus 2, Jasione montana + , Anthemis cretica subsp. calabrica 1, Bromus erectus +, Phleum hirsutum subsp. ambiguum 1, Plantago maritima subsp. serpentina 2, Aira caryophyllea 1, Koeleria splendens subsp. brutia 1, Petrorhagia saxifraga subsp. gasparrinii 1, Hypericum calabricum 1 , Anthoxantum odoratum + , Viola aethnensis subsp. messanensis + , Luzula multiflora + , Helianthemum nummularium subsp. tomentosum 1, Thymus longicaulis 2, Armeria brutia 1, Festuca circummediterranea 1, Sedum amplexicaule subsp. tenuifolium + , Anthyllis vulneraria subsp. maura + , Avenula praetutiana subsp. rigida 1, Bunium bulbocastanum +, Hieracium pilosella + , Clinopodium vulgare + , Pinus nigra subsp. calabrica + , Thesium humifusum +, Genista silana 1, Helichrysum italicum +, Scrophularia scopolii +, Lotus corniculatus +.

Type relevé of Asperulo purpureae-Brometum erecti Biondi \& Ballelli ex Di Pietro ass. nov. Rel. 3 of Table 3 in: Ballelli \& Biondi 1982 (Carta della vegetazione del Foglio Pergola, 1:50.000. P.F. "Promozione della qualità dell'ambiente", C.N.R., Roma, 1982, AQ/1/86, 1-33). Site: Colle Aiale, 31.7.1981. AUThors Ballelli S. \& Biondi E. Altitude: 278 m, Aspect: SE, Slope 45ㅇ, Cover 
95\%, Area: $100 \mathrm{~m}^{2}$. List of SPECIES: Asperula purpurea 1, Eryngium amethystinum 1, Crepis lacera + , Satureja montana 2, Stachys recta subsp. recta +, Petrorhagia saxifraga + , Reichardia picroides +, Globularia punctata + , Teucrium capitatum 1, Pimpinella saxifraga + , Cephalaria leucantha + , Phleum hirsutum subsp. ambiguum 1, Hippocrepis comosa 1 , Bromus erectus 2, Teucrium chamaedrys 1 , Artemisia alba 1, Dianthus sylvestris s.l. +, Linum tenuifolium + , Sanguisorba minor subsp. balearica + , Convolvulus cantabrica +, Spartium junceum +, Orchis pur- purea + , Brachypodium rupestre 2, Allium tenuiflorum 1, Thymus longicaulis +, Hieracium pilosella +, Lactuca perennis +, Helichrysum italicum 1, Galium lucidum +, Knautia arvensis +, Sedum acre +, Silene vulgaris + , Erysimum pseudorhaeticum + , Dactylis glomerata + , Carlina acanthifolia subsp. acanthifolia + , Cuscuta epithymum subsp. epithymum + , Lotus corniculatus +, Hypericum perforatum 1, Leontodon hispidus +, Sedum album +, Linum bienne + , Inula montana +, Echium vulgare +, Avena barbata + , Asparagus acutifolius + .

Table 1 (Tabela 1): Violo pseudogracilis-Koelerietum splendentis ass. nov.

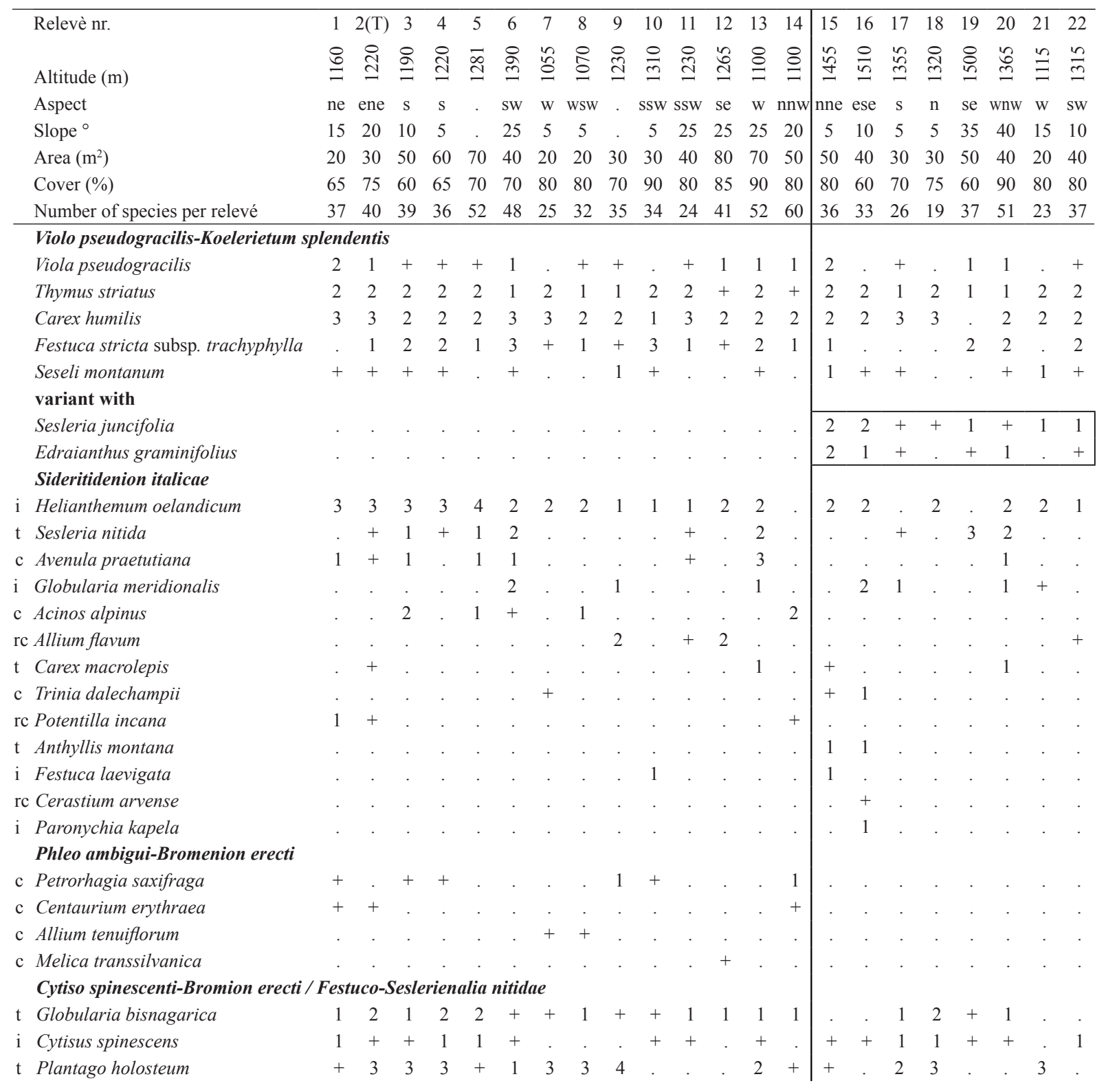




\begin{tabular}{|c|c|c|c|c|c|c|c|c|c|c|c|c|c|c|c|c|c|c|c|c|c|c|}
\hline Relevè nr. & 1 & $2(\mathrm{~T})$ & 3 & 4 & 5 & 6 & 7 & 8 & 9 & 10 & 11 & 12 & 13 & 14 & 15 & 16 & 17 & 18 & 19 & 20 & 21 & 22 \\
\hline c Festuca inops & 1 & 2 & . & . & 3 & . & 2 & 2 & 1 & 1 & . & . & . & 2 & 2 & . & 2 & 1 & . & 1 & 2 & 3 \\
\hline t Galium corrudifolium & 1 & + & . & . & . & 1 & 1 & 1 & . & + & 1 & . & 1 & . & 1 & . & 1 & + & + & 1 & 1 & . \\
\hline rc Potentilla pedata & + & . & 1 & 1 & + & . & . & 1 & + & 1 & . & + & + & 1 & . & . & . & + & . & + & + & + \\
\hline i Onosma echioides & . & 1 & 1 & + & + & + & . & + & . & . & + & . & 1 & . & . & + & + & + & 1 & . & . & + \\
\hline rc Thlaspi praecox & + & + & . & . & + & + & . & . & . & . & + & + & + & + & . & + & . & . & . & + & . & . \\
\hline t Asperula aristata & + & . & . & . & . & + & . & . & + & . & + & 2 & . & . & . & + & . & . & + & + & . & + \\
\hline i Euphorbia spinosa & . & . & . & + & . & . & . & . & . & + & 1 & + & 1 & . & . & . & + & . & + & . & . & 1 \\
\hline c Crepis lacera & . & . & . & . & + & + & . & . & + & + & . & + & + & + & . & . & . & . & . & . & . & . \\
\hline c Ornithogalum gussonei & + & + & . & . & + & . & . & + & + & . & . & . & . & . & + & + & . & . & . & . & . & . \\
\hline c Laserpitium siler & . & . & . & . & + & + & . & . & . & . & . & . & . & . & + & + & . & . & 2 & . & . & + \\
\hline c Centaurea deusta & . & . & . & . & . & . & + & . & . & . & . & . & . & 1 & . & + & + & . & 1 & . & . & . \\
\hline c Phleum hirsutum & . & . & . & . & . & 1 & . & . & . & . & . & 1 & 1 & 1 & . & . & . & . & 1 & . & . & . \\
\hline t Aethionema saxatile & . & . & 1 & 1 & 1 & . & . & . & . & . & . & + & . & . & . & . & . & . & 1 & . & . & . \\
\hline rc Orchis pauciflora & . & . & . & + & . & . & . & . & . & . & . & + & . & . & + & . & . & . & . & + & . & + \\
\hline rc Scabiosa holosericea & 1 & + & . & . & . & . & . & . & . & . & . & . & 1 & . & . & . & . & . & 1 & . & . & . \\
\hline rc Helianthemum apenninum & . & . & . & . & . & . & . & . & 2 & . & . & . & . & 1 & . & . & 1 & + & . & . & . & . \\
\hline c Stipa dasyvaginata & . & . & 1 & . & + & . & . & . & . & . & . & . & . & . & . & . & . & . & . & . & . & . \\
\hline rc Alyssum diffusum & . & . & . & . & 1 & . & . & . & . & . & . & . & . & . & . & 1 & . & . & . & . & . & . \\
\hline \multicolumn{23}{|l|}{ Artemisio albae-Brometalia erecti } \\
\hline Koeleria splendens & 3 & 3 & 2 & 3 & 2 & 3 & 3 & 3 & 3 & 3 & 3 & 3 & 3 & 3 & 3 & 3 & 3 & 3 & 2 & 3 & 3 & 3 \\
\hline Anthyllis vulneraria & + & + & + & 1 & 1 & + & . & . & + & 1 & . & + & 1 & 1 & + & 1 & 1 & + & 1 & + & + & . \\
\hline Teucrium montanum & 2 & 1 & . & . & 1 & 1 & 1 & 1 & 2 & 1 & 1 & 2 & 1 & 1 & + & . & + & 2 & . & + & + & + \\
\hline Asperula purpurea & . & 2 & 1 & 1 & 1 & + & + & + & . & + & + & . & 2 & . & . & . & 1 & 1 & + & 1 & . & . \\
\hline Satureja montana & . & + & + & 1 & 2 & . & . & . & 1 & + & 1 & 2 & 2 & 2 & . & . & . & + & . & 1 & . & . \\
\hline Thesium humifusum & . & 1 & + & . & . & 1 & 1 & . & + & + & + & . & 1 & . & . & 1 & + & . & 1 & 1 & . & . \\
\hline Teucrium chamaedrys & . & 1 & + & . & 2 & 1 & . & . & 1 & . & 1 & 2 & 1 & 1 & . & + & . & . & + & . & . & . \\
\hline Leontodon crispus & + & . & 1 & . & 1 & 1 & + & . & + & . & . & . & . & + & . & . & . & . & + & + & . & 1 \\
\hline Helianthemum nuтmularium & . & . & 2 & 1 & 1 & 1 & . & + & . & . & . & 1 & 1 & . & . & . & . & . & . & 1 & + & . \\
\hline Allium sphaerocephalon & . & . & . & . & + & . & + & . & + & 1 & . & 1 & . & 1 & + & . & . & . & + & . & . & 1 \\
\hline Muscari neglectum & + & . & + & + & 1 & . & . & . & . & 1 & . & . & . & 1 & + & + & . & + & . & . & . & . \\
\hline Eryngium amethystinum & + & . & . & + & . & + & + & . & + & . & . & 1 & + & 1 & . & . & . & . & . & . & + & . \\
\hline Festuca circummediterranea & . & . & . & . & . & 1 & . & . & . & + & . & + & 2 & . & . & + & . & . & 1 & 1 & . & + \\
\hline Knautia purpurea & . & . & . & . & . & + & + & 1 & + & + & + & . & + & . & . & . & . & . & . & 1 & . & . \\
\hline Hippocrepis comosa & . & + & . & + & + & . & . & + & . & . & . & + & 1 & . & . & . & . & . & . & 1 & . & . \\
\hline Biscutella laevigata & . & . & . & . & . & + & . & . & + & . & . & . & . & . & 1 & 1 & + & . & . & + & . & + \\
\hline Inula hirta & + & 1 & . & + & . & . & + & + & . & . & . & . & 1 & . & . & . & . & . & . & . & . & . \\
\hline Linum tenuifolium & . & 1 & . & . & . & 1 & . & . & . & . & . & 1 & + & . & . & . & + & . & 1 & . & . & . \\
\hline Polygala major & . & 1 & . & + & . & . & . & . & . & . & . & . & . & + & . & . & . & . & 1 & 2 & . & + \\
\hline Cyanus triumfetti & . & + & . & . & + & + & . & . & . & . & . & . & 1 & . & . & . & . & . & 1 & + & . & . \\
\hline Narcissus poeticus & . & . & . & . & . & 1 & . & . & . & . & . & . & . & . & + & + & . & . & . & + & . & . \\
\hline Galium lucidum & . & . & . & . & + & . & . & . & . & . & . & + & . & + & . & . & . & . & . & . & . & . \\
\hline Dianthus sylvestris & . & . & . & . & . & . & . & . & . & . & . & . & . & . & . & . & . & . & . & + & + & + \\
\hline Pseudolysimachion barrelieri & . & + & . & . & . & . & + & 1 & . & . & . & . & . & . & . & . & . & . & . & . & . & . \\
\hline Hieracium piloselloides & + & . & . & . & . & . & . & . & + & . & . & . & . & . & . & . & . & . & . & . & . & . \\
\hline Bunium bulbocastanum & . & . & . & . & . & . & . & . & . & . & . & . & . & 1 & . & . & . & . & . & + & . & . \\
\hline Orchis tridentata & . & . & . & + & . & . & . & . & . & . & . & . & . & . & . & . & . & . & . & . & . & . \\
\hline Inula montana & . & . & . & . & + & . & . & . & . & . & . & . & . & . & . & . & . & . & . & . & . & . \\
\hline Stachys recta & . & . & . & . & . & . & . & . & . & . & . & . & . & . & . & . & . & . & . & . & . & 1 \\
\hline Brachypodium rupestre & . & . & . & . & . & . & . & . & . & . & . & . & 2 & . & . & . & . & . & . & . & . & . \\
\hline Scabiosa columbaria & . & . & . & . & . & . & . & . & . & . & . & . & + & . & . & . & . & . & . & . & . & . \\
\hline \multicolumn{23}{|l|}{ Festuco-Brometea } \\
\hline Bromus erectus & . & 1 & 1 & 2 & 1 & 3 & . & . & . & 2 & 2 & 1 & 2 & 2 & 1 & + & . & . & 2 & 2 & . & 2 \\
\hline Cerastium arvense & . & . & + & 1 & 1 & + & . & . & + & + & . & + & 1 & + & . & . & . & . & . & . & + & + \\
\hline Thymus longicaulis & . & . & . & . & . & 1 & . & + & . & + & . & . & 1 & . & + & + & 1 & + & . & + & + & + \\
\hline Herniaria glabra & + & . & 1 & 1 & + & . & . & + & . & + & . & + & . & 1 & + & . & . & . & . & . & . & . \\
\hline
\end{tabular}




\begin{tabular}{|c|c|c|c|c|c|c|c|c|c|c|c|c|c|c|c|c|c|c|c|c|c|c|}
\hline Relevè nr. & 1 & $2(\mathrm{~T})$ & 3 & 4 & 5 & 6 & 7 & 8 & 9 & 10 & 11 & 12 & 13 & 14 & 15 & 16 & 17 & 18 & 19 & 20 & 21 & 22 \\
\hline Sanguisorba minor & 1 & 1 & . & . & . & + & . & 1 & . & . & . & . & 1 & . & . & . & + & . & + & . & + & . \\
\hline Cerastium ligusticum & . & . & + & + & 1 & . & . & . & + & . & . & . & . & + & . & . & . & . & . & . & . & . \\
\hline Plantago argentea & . & . & . & . & + & 1 & . & . & . & . & . & . & . & . & + & . & . & . & . & 2 & . & . \\
\hline Euphorbia cyparissias & . & . & . & . & . & + & . & . & . & . & . & + & . & . & . & . & . & . & + & + & . & . \\
\hline Lotus corniculatus & . & . & . & . & . & + & . & + & . & . & . & . & . & . & . & . & . & . & . & + & . & . \\
\hline Gymnadenia conopsea & . & . & . & . & . & 1 & . & . & . & . & . & . & . & . & + & . & . & . & . & + & . & . \\
\hline Euphrasia salisburgensis & . & . & . & . & . & . & 1 & . & . & . & . & + & . & . & . & . & . & . & . & . & + & . \\
\hline Carex caryophyllea & 1 & . & . & . & . & . & . & . & . & . & . & . & + & . & . & . & . & . & . & . & . & . \\
\hline Euphrasia stricta & + & . & . & . & . & . & . & . & . & . & . & . & . & 1 & . & . & . & . & . & . & . & . \\
\hline Medicago lupulina & . & . & . & . & 1 & . & . & . & . & . & . & . & . & + & . & . & . & . & . & . & . & . \\
\hline Trifolium campestre & . & . & . & . & . & . & . & + & . & . & . & . & . & + & . & . & . & . & . & . & . & . \\
\hline Carduus micropterus & . & . & . & . & . & . & . & . & . & + & . & . & . & . & . & . & . & . & . & . & . & + \\
\hline Rhinanthus alectorolophus & . & . & . & . & . & . & . & . & . & . & . & . & . & . & . & . & . & . & 1 & . & . & + \\
\hline Hieracium pilosella & 1 & . & . & . & . & . & . & . & . & . & . & . & . & . & . & . & . & . & . & . & . & . \\
\hline Linum catharticum & . & + & . & . & . & . & . & . & . & . & . & . & . & . & . & . & . & . & . & . & . & . \\
\hline Trifolium strictum & . & . & . & . & + & . & . & . & . & . & . & . & . & . & . & . & . & . & . & . & . & . \\
\hline Prunella laciniata & . & . & . & . & . & . & . & + & . & . & . & . & . & . & . & . & . & . & . & . & . & . \\
\hline Carduus nutans & . & . & . & . & . & . & . & . & . & . & . & + & . & . & . & . & . & . & . & . & . & . \\
\hline Trifolium ochroleucum & . & . & . & . & . & . & . & . & . & . & . & . & + & . & . & . & . & . & . & . & . & . \\
\hline Anthemis arvensis & . & . & . & . & . & . & . & . & . & . & . & . & . & + & . & . & . & . & . & . & . & . \\
\hline Bromus hordeaceus & . & . & . & . & . & . & . & . & . & . & . & . & . & + & . & . & . & . & . & . & . & . \\
\hline Plantago lanceolata & . & . & . & . & . & . & . & . & . & . & . & . & . & + & . & . & . & . & . & . & . & . \\
\hline Knautia arvensis & . & . & . & . & . & . & . & . & . & . & . & . & . & . & . & . & . & . & + & . & . & . \\
\hline Geranium pyrenaicum & . & . & . & . & . & . & . & . & . & . & . & . & . & . & . & . & . & . & . & + & . & . \\
\hline Arabis sagittata & . & . & . & . & . & . & . & . & . & . & . & . & . & . & . & . & . & . & . & + & . & + \\
\hline Heliantheтит nиттиlarium & . & . & . & . & + & . & . & . & . & . & . & . & . & . & . & . & . & . & . & . & . & . \\
\hline \multicolumn{23}{|l|}{ Other species } \\
\hline Sedum rupestre & + & . & 1 & 1 & . & + & + & + & . & + & . & 1 & + & + & 1 & + & . & . & . & + & + & 1 \\
\hline Genista tinctoria & + & 1 & . & . & . & . & . & + & . & . & . & + & 1 & . & . & . & . & . & . & + & + & . \\
\hline Rosa spinosissima & + & + & . & . & + & + & . & . & . & . & . & . & 1 & . & . & . & . & . & + & + & . & . \\
\hline Sedum album & . & . & 1 & + & 1 & . & . & . & . & + & . & . & . & . & + & . & . & . & . & . & . & 1 \\
\hline Thalictrum minus & . & + & . & . & + & . & . & . & . & . & . & . & . & + & + & . & . & . & . & + & . & . \\
\hline Bombycilaena erecta & . & . & . & 1 & . & . & . & . & + & + & . & . & . & + & . & . & . & . & . & . & . & . \\
\hline Poa bulbosa & . & . & 1 & . & 1 & . & . & . & + & . & . & . & . & + & . & . & . & . & . & . & . & . \\
\hline Bupleurum baldense & . & . & . & . & . & . & + & . & . & . & . & . & + & 1 & . & . & . & . & . & . & . & . \\
\hline Asphodelus albus & . & . & . & + & . & + & . & . & . & . & . & . & . & . & . & . & . & . & + & . & . & . \\
\hline Salvia officinalis & . & . & . & . & + & . & . & 1 & . & . & . & . & 2 & . & . & . & . & . & . & . & . & . \\
\hline Fumana procumbens & . & . & . & . & . & . & . & + & . & . & . & + & . & . & . & . & . & . & . & . & + & . \\
\hline Genista januensis & . & . & . & . & . & . & . & . & . & . & . & . & . & . & + & + & . & . & + & . & . & . \\
\hline Orobanche teucrii & + & + & . & . & . & . & . & . & . & . & + & . & . & . & . & . & . & . & . & . & . & . \\
\hline Sorbus aria & + & . & . & . & . & . & . & . & . & . & . & . & . & . & . & . & . & . & . & + & . & . \\
\hline Arenaria serpyllifolia & . & . & + & . & + & . & . & . & . & . & . & . & . & . & . & . & . & . & . & . & . & . \\
\hline Saxifraga tridactylites & . & . & + & . & + & . & . & . & . & . & . & . & . & . & . & . & . & . & . & . & . & . \\
\hline Crepis neglecta & . & . & 1 & . & . & . & . & . & . & . & . & . & . & 1 & . & . & . & . & . & . & . & . \\
\hline Geranium sanguineum & . & . & . & . & + & $\cdot$ & . & . & . & . & . & . & + & . & . & . & . & . & . & . & . & . \\
\hline Orobanche gracilis & . & . & . & . & . & + & . & . & . & . & . & . & . & . & . & . & . & . & . & + & . & . \\
\hline Polygala alpestris & . & . & . & . & . & + & . & . & . & . & . & . & . & . & . & 1 & . & . & . & . & . & . \\
\hline Catapodium rigidum & . & . & . & . & . & . & . & . & + & . & . & . & . & + & . & . & . & . & . & . & . & . \\
\hline Poa molinerii & . & . & . & . & . & . & . & . & . & 2 & . & . & . & . & . & . & . & . & . & . & . & 2 \\
\hline Cuscuta epithymum & . & . & . & . & . & . & . & . & . & . & . & 1 & + & . & . & . & . & . & . & . & . & . \\
\hline Iris relicta & . & . & . & . & . & . & . & . & . & . & . & 3 & . & 2 & . & . & . & . & . & . & . & . \\
\hline Sempervivum tectorum & . & . & . & . & . & . & . & . & . & . & . & . & . & . & 1 & 1 & . & . & . & . & . & . \\
\hline Daphne oleoides & . & . & . & . & . & . & . & . & . & . & . & + & . & . & . & . & . & . & . & . & . & . \\
\hline
\end{tabular}

CAPTION: c: characteristic; rc: regional character.; pc: partial character., t: transgressive; i: ingressive 
Table 2 (Tabela 2): Helichryso italici-Brometum erecti ass. nov.

\begin{tabular}{|c|c|c|c|c|c|c|c|c|c|c|c|c|c|c|c|c|c|c|c|c|c|c|c|c|c|c|c|c|}
\hline & Relevè nr. & 1 & 2 & 3 & 4 & 5 & $\begin{array}{c}6 \\
(\mathrm{~T})\end{array}$ & 7 & 8 & 9 & 10 & 11 & & 13 & $\begin{array}{l}14 \\
(\mathrm{t})\end{array}$ & 15 & & & & & & & & 23 & 24 & 25 & & 27 \\
\hline & Altitude (m) & $\ddot{n}$ & $\stackrel{n}{n}$ & $\stackrel{n}{\stackrel{n}{r}}$ & $\stackrel{n}{n}$ & $\stackrel{\infty}{+}$ & $\frac{n}{6}$ & శ్రి & 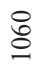 & $\stackrel{?}{0}$ & $\frac{n}{a}$ & $\dddot{\curvearrowright}$ & $\tilde{\kappa}$ & $\dddot{2}$ & 8 & $\stackrel{\infty}{\triangleright}$ & $\stackrel{8}{2}$ & $\tilde{6}$ & $\stackrel{\nwarrow}{్}$ & $\stackrel{2}{2}$ & 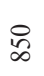 & $\tilde{n}$ & $\stackrel{\circ}{7}$ & 8 & \&্+ & ถి & 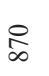 & $\stackrel{\infty}{\triangleright}$ \\
\hline & Aspect & 0 & 0 & 点 & $\mathscr{m}$ & 竧 & 点 & 房 & 尝 & $\begin{array}{l}3 \\
3 \\
3\end{array}$ & 咅 & in & 勇 & 空 & 0 & & $=$ & 总 & 光 & 总 & 3 & $\stackrel{\Xi}{0}$ & \& & . & $\ddot{\delta}$ & 勇 & 蛋 & in \\
\hline & Slope $\left(^{\circ}\right)$ & 25 & 35 & 25 & 20 & 30 & 25 & 5 & 20 & 15 & 25 & 35 & 25 & 35 & 20 & . & 10 & 30 & 15 & 20 & 30 & 10 & 20 & 2 & 30 & 25 & 25 & 10 \\
\hline & Area (m & 30 & 50 & 70 & 60 & 50 & 50 & 40 & 40 & 40 & 50 & 50 & 50 & 40 & 30 & 30 & 30 & 40 & 30 & 40 & 40 & 40 & 30 & 35 & 70 & 50 & 40 & 50 \\
\hline & Cover $(\%)$ & 70 & 75 & 65 & 90 & 80 & 90 & 90 & 85 & 80 & 80 & 80 & 80 & 70 & 80 & 60 & 70 & 80 & 95 & 90 & 90 & 85 & 85 & 90 & 80 & 80 & 70 & 80 \\
\hline & Number of species per relevé & 46 & 50 & 52 & 74 & 45 & 78 & 28 & 33 & 32 & 47 & 44 & 50 & 49 & 75 & 34 & 36 & 55 & 60 & 69 & 64 & 60 & 55 & 52 & 72 & 54 & 66 & 74 \\
\hline & Helichryso italici-Brometum & & & & & & & & & & & & & & & & & & & & & & & & & & & \\
\hline & Helichrysum italicum & 3 & 3 & 3 & 2 & 2 & 2 & 2 & 1 & 2 & 2 & + & 1 & 1 & 1 & + & + & . & . & + & . & . & . & . & 1 & 3 & 3 & + \\
\hline & Centaurea deusta & + & 1 & + & + & 1 & + & + & + & . & 1 & 2 & . & . & 1 & + & 2 & 3 & 1 & + & 1 & . & . & 1 & . & + & + & 3 \\
\hline & Melica transsilvanica & 1 & + & + & + & + & 1 & 1 & . & . & . & . & . & . & 2 & + & 1 & 1 & . & + & . & . & 1 & 1 & 1 & . & 2 & 2 \\
\hline & Centaurium erythraea & . & + & + & + & . & 1 & + & . & . & + & . & . & + & + & + & + & . & 1 & + & . & . & 1 & + & . & . & + & . \\
\hline & Sedum sexangulare & 1 & . & + & + & + & + & 1 & . & + & . & + & . & . & + & . & . & . & + & + & 1 & + & . & 3 & . & 1 & . & . \\
\hline & $\begin{array}{l}\text { Micromeria graeca } \\
\text { subass. }\end{array}$ & + & + & + & 1 & 1 & 1 & 2 & + & . & . & . & . & . & 1 & . & 1 & + & + & . & + & . & 1 & + & + & + & . & 1 \\
\hline & Satureja montana & . & . & . & . & . & . & . & . & . & . & 1 & 1 & 2 & 1 & 3 & 2 & + & + & 1 & 3 & 3 & . & + & 2 & 1 & 3 & 2 \\
\hline & Euphorbia spinosa & . & . & . & . & . & . & . & . & . & . & 3 & . & 2 & 2 & 2 & 1 & 2 & . & 2 & 3 & 2 & . & 1 & 1 & 3 & 2 & 3 \\
\hline & Linum tenuifolium & . & . & . & . & . & . & . & . & . & . & 1 & 1 & . & + & . & . & . & 1 & . & . & + & + & + & . & 1 & 1 & + \\
\hline & Phleo ambigui-Bromenion ere & & & & & & & & & & & & & & & & & & & & & & & & & & & \\
\hline $\mathrm{i}$ & Bupleurum baldense & + & + & + & + & + & + & + & . & . & . & + & + & . & + & . & . & + & + & 1 & + & + & + & + & + & 1 & + & + \\
\hline $\mathrm{c}$ & Convolvulus cantabrica & + & 1 & 1 & + & + & 1 & + & . & . & . & 1 & . & . & 1 & . & . & + & . & + & . & . & . & 1 & + & 1 & . & 1 \\
\hline $\mathrm{rc}$ & Elaeoselinum asclepium & + & . & + & . & . & . & . & . & + & . & + & . & . & + & + & 1 & 1 & . & . & . & . & 1 & 1 & + & + & + & 2 \\
\hline $\mathrm{i}$ & Reichardia picroides & . & + & . & + & 1 & 1 & + & . & . & . & . & . & . & + & . & . & + & . & 1 & . & . & 1 & . & 1 & 1 & + & 1 \\
\hline $\mathrm{i}$ & Linum strictum & . & . & . & + & + & + & . & . & . & . & . & + & + & + & + & . & 1 & . & . & + & + & . & + & . & . & + & 1 \\
\hline $\mathrm{c}$ & Cephalaria leucantha & 1 & . & . & + & . & . & 1 & . & . & . & . & . & 1 & + & 1 & 2 & 1 & . & . & . & . & 1 & . & . & 1 & 1 & 1 \\
\hline $\mathrm{i}$ & Brachypodium retusum & . & + & . & + & 1 & + & . & . & . & . & . & . & . & 3 & 2 & 3 & 1 & . & . & . & . & 1 & . & 3 & . & 2 & + \\
\hline $\mathrm{i}$ & Urospermum dalechampii & . & + & . & + & . & + & . & . & . & . & . & . & . & + & + & . & . & + & + & . & . & . & 1 & 1 & + & + & 1 \\
\hline $\mathrm{i}$ & Carlina corymbosa & + & . & + & + & + & 1 & 1 & . & . & . & . & . & . & . & . & . & . & . & 1 & . & . & . & . & + & . & 1 & + \\
\hline $\mathrm{i}$ & Cynosurus echinatus & . & . & . & . & + & + & . & . & . & . & . & + & . & 1 & . & . & . & . & . & + & . & + & 1 & 1 & 1 & . & + \\
\hline $\mathrm{c}$ & Carex flacca & . & + & . & + & 1 & 1 & 2 & . & . & . & . & + & . & . & . & . & 2 & . & . & . & . & + & . & + & . & . & . \\
\hline $\mathrm{c}$ & Crupina vulgaris & . & . & . & + & 1 & . & . & . & . & . & . & + & 1 & 1 & . & 1 & 1 & . & . & . & . & . & . & 1 & . & 1 & . \\
\hline $\mathrm{c}$ & Ononis pusilla & . & + & + & + & + & + & . & . & . & . & . & . & 1 & . & 1 & . & . & . & . & . & . & . & . & . & 1 & + & . \\
\hline $\mathrm{i}$ & Linum strictum & . & . & . & . & . & 1 & . & . & . & . & 1 & . & . & . & . & . & 1 & . & 1 & . & . & . & 1 & 1 & 1 & . & . \\
\hline $\mathrm{i}$ & Petrorhagia saxifraga & . & . & . & . & . & . & . & . & . & . & . & . & . & . & . & . & . & . & + & . & + & . & + & 1 & 1 & . & + \\
\hline $\mathrm{c}$ & Crepis neglecta & . & . & . & + & . & + & . & . & . & . & + & . & . & . & . & . & . & . & + & . & . & . & . & 1 & . & . & . \\
\hline $\mathrm{i}$ & Sideritis romana & . & . & . & . & . & . & . & . & . & . & . & . & . & + & . & . & + & . & + & . & . & . & + & . & . & . & 1 \\
\hline $\mathrm{i}$ & Medicago minima & . & . & . & + & . & + & . & . & . & . & . & . & . & . & . & . & . & . & . & + & . & . & . & + & . & . & 1 \\
\hline $\mathrm{i}$ & Avena barbata & . & . & . & + & . & . & . & . & . & . & 1 & . & . & . & . & . & + & . & 2 & . & . & . & . & . & . & . & 1 \\
\hline $\mathrm{pc}$ & Asphodeline liburnica & . & . & . & . & . & . & . & . & . & . & . & . & . & 1 & 2 & 3 & . & . & . & . & . & . & 2 & . & . & . & . \\
\hline $\mathrm{i}$ & Ononis reclinata & . & . & . & . & . & + & . & . & . & . & . & . & + & . & . & . & . & . & . & . & . & . & 1 & . & . & + & . \\
\hline $\mathrm{i}$ & Fumana thymifolia & . & . & . & . & . & . & . & . & . & . & . & . & . & . & . & . & 2 & . & . & . & . & 2 & 1 & . & . & . & . \\
\hline $\mathrm{c}$ & Hieracium cymosum & . & . & . & . & . & . & . & . & . & . & + & . & . & . & . & . & . & . & . & . & . & . & . & . & . & . & . \\
\hline $\mathrm{c}$ & Trifolium strictum & . & . & . & . & . & . & . & 1 & . & . & . & . & . & . & . & . & . & . & . & . & . & . & . & . & . & . & . \\
\hline $\mathrm{c}$ & Dasypyrum villosum & . & . & . & . & . & . & . & . & . & . & + & . & . & . & . & . & . & . & . & . & . & . & . & . & . & . & . \\
\hline $\mathrm{c}$ & Linum bienne & . & . & . & . & . & . & . & . & . & & . & . & . & + & . & . & + & . & . & . & . & . & . & . & . & . & . \\
\hline $\mathrm{c}$ & Silene gallica & . & . & . & . & . & . & . & . & . & . & . & . & . & . & . & . & . & . & + & . & . & . & . & . & . & . & . \\
\hline $\mathrm{c}$ & Allium tenuiflorum & . & . & . & . & . & . & . & . & . & & . & . & . & . & . & . & . & . & . & . & . & . & . & . & . & . & + \\
\hline $\mathrm{i}$ & Trigonella monspeliaca & . & . & . & . & . & . & . & . & . & & . & . & . & . & . & . & . & . & . & + & . & . & . & . & . & . & . \\
\hline $\mathrm{i}$ & Teucrium capitatum & . & . & . & . & $\cdot$ & . & . & . & . & & . & . & . & . & . & . & . & . & . & . & . & & . & & . & . & + \\
\hline
\end{tabular}


Relevè nr.

\section{Sideritidenion italicae}

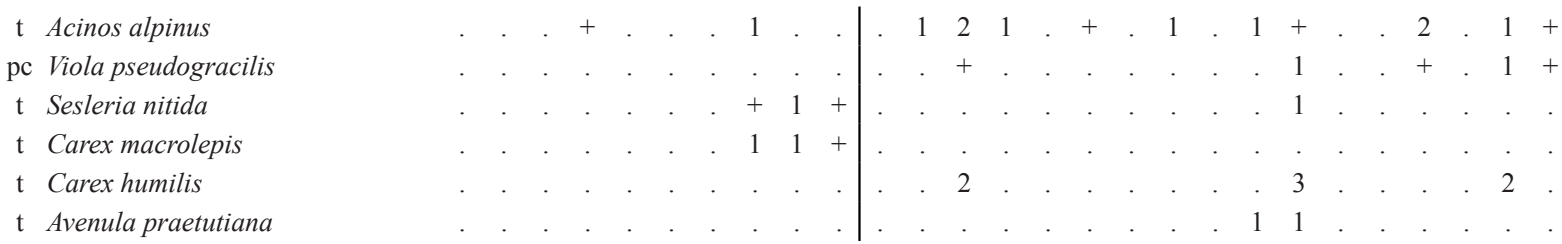

Cytiso spinescenti-Bromion erecti / Festuco-Seslerienalia nitidae

$\mathrm{t}$ Galium corrudifolium

rc Potentilla pedata

t Festuca stricta

t Globularia bisnagarica

$\mathrm{t}$ Aethionema saxatile

c Festuca inops

c Crepis lacera

rc Thlaspi praecox

rc Orchis pauciflora

i Cytisus spinescens

c Phleum hirsutum

c Thymus striatus

t Asperula aristata

c Ornithogalum gussonei

c Polygala flavescens

c Laserpitium siler

c Scabiosa holosericea

c Festuca robustifolia

rc Helianthemum apenninum

rc Ruta graveolens

$\mathrm{t}$ Ranunculus millefoliatus

i Onosma echioides

c Stipa dasyvaginata

rc Argyrolobium zanonii

pc Ophrys lacaitae

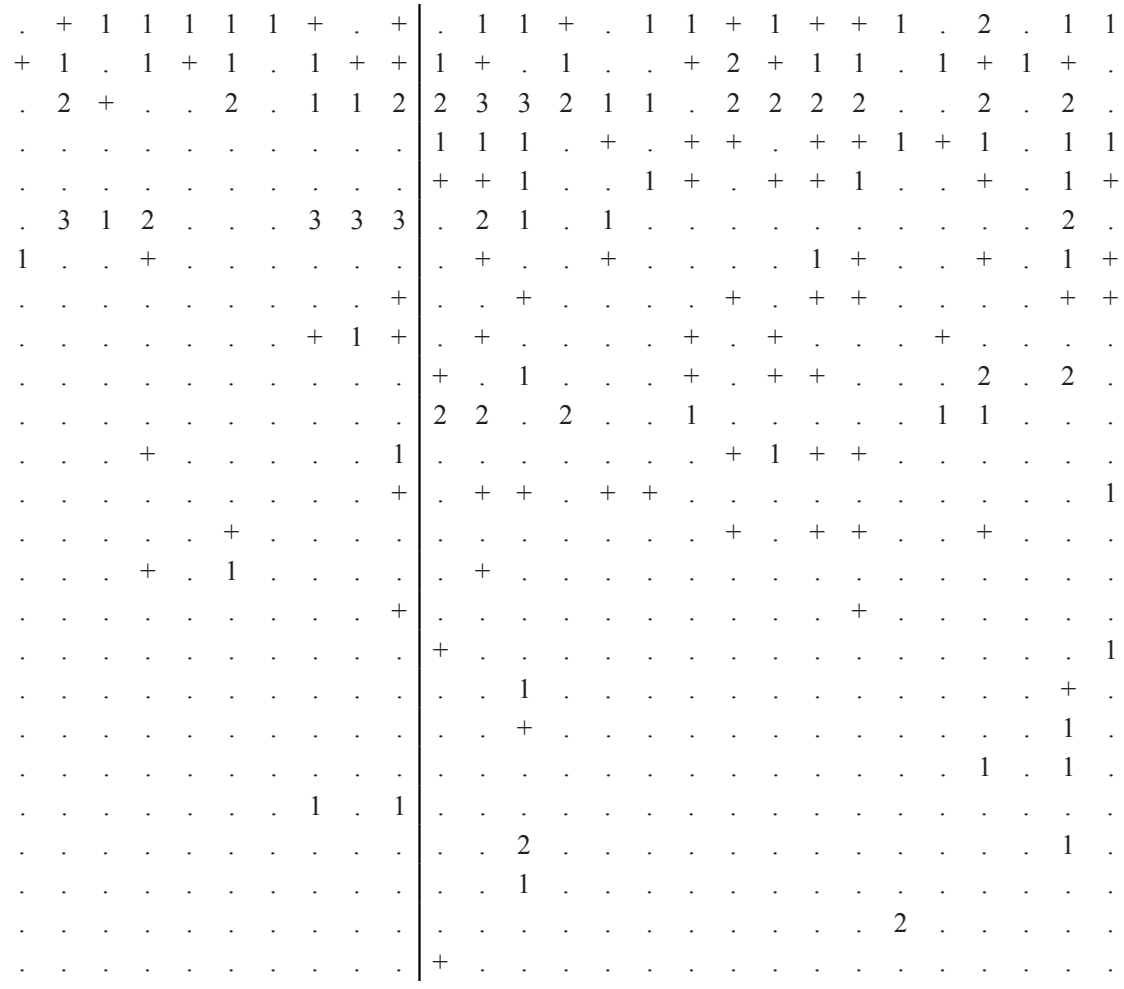

Artemisio albae-Brometalia erecti

Teucrium chamaedrys

Koeleria splendens

Helianthemum nummularium

Eryngium amethystinum

Stachys recta

Anthyllis vulneraria

Teucrium montanum

Festuca circummediterranea

Thesium humifusum

Dianthus sylvestris

Scabiosa columbaria

Knautia purpurea

Leontodon crispus

Hippocrepis comosa

Galium lucidum

Muscari neglectum

Asperula purpurea

Arabis collina

Narcissus poeticus

Cyanus triumfetti

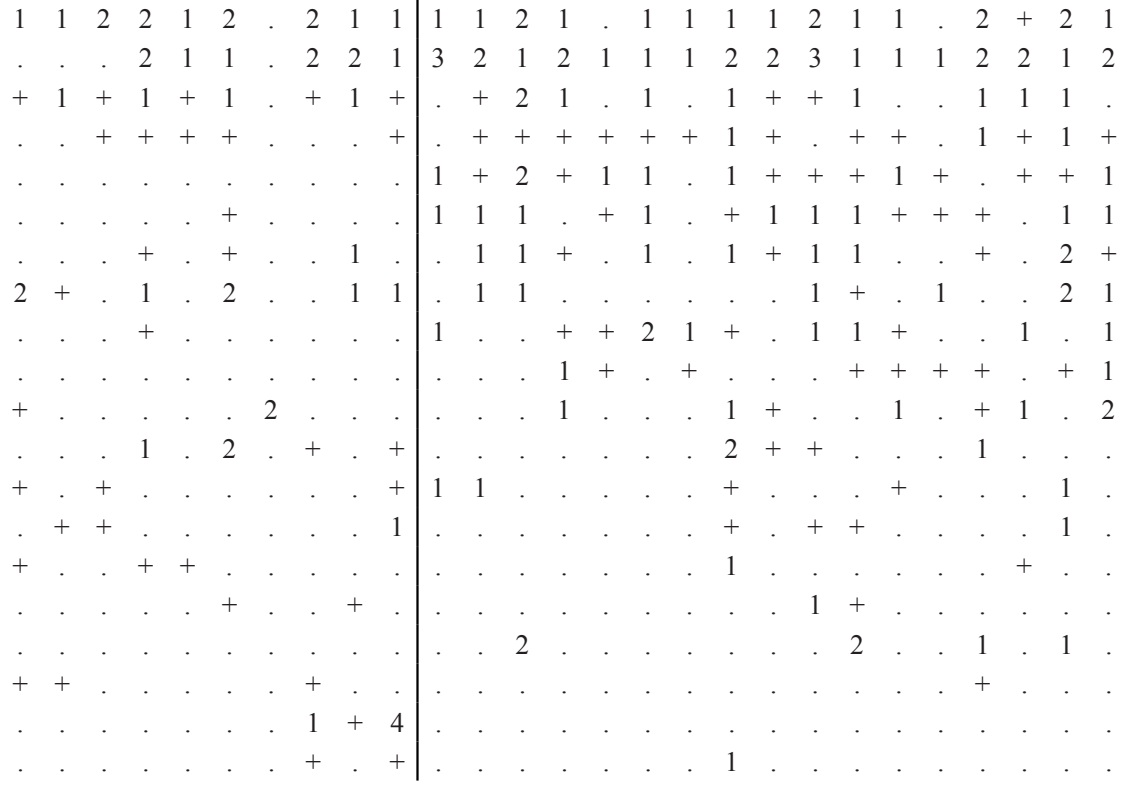


Allium sphaerocephalon (t)

Brachypodium rupestre

Seseli montanum

Arabis sagittata

Orchis anthropophora

Anthericum liliago

Biscutella laevigata

Asphodeline lutea

Hieracium piloselloides

Bunium bulbocastanum

Ophrys holosericea

Festuco-Brometea

Bromus erectus

Plantago lanceolata

Sanguisorba minor

Dactylis glomerata

Thymus longicaulis

Carduus nutans

Trifolium campestre

Medicago lupulina

Lotus corniculatus

Carex caryophyllea

Cerastium ligusticum

Cerastium arvense

Prunella laciniata

Hieracium pilosella

Geranium pyrenaicum

Tanacetum corymbosum

Trifolium ochroleucum

Euphrasia stricta

Anthemis arvensis

Leontodon hispidus

Ranunculus bulbosus

Bromus hordeaceus

Herniaria glabra

Crocus biflorus

Ophrys apifera

Daucus carota

Filipendula vulgaris

Euphrasia salisburgensis

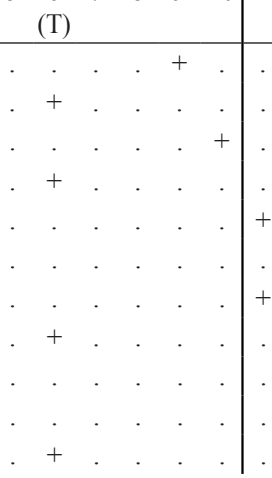

\begin{tabular}{llllllllll|lllllllllllllllll}
3 & 2 & 3 & 3 & 3 & 3 & 3 & 2 & 2 & 3 & 3 & 3 & 2 & 3 & 1 & 1 & 3 & 3 & 3 & 4 & 3 & 3 & 2 & 1 & 2 & 3 & 3
\end{tabular}

Lygeo-Stipetea + Tuberarietea

Catapodium rigidum

Hypochaeris achyrophorus

Trifolium scabrum

Ampelodesmos mauritanicus

Trachynia distachya

Hippocrepis biflora

Coronilla scorpioides

Blackstonia perfoliata

Briza maxima

Trifolium stellatum

Bromus madritensis

Linum trigynum

Euphorbia exigua
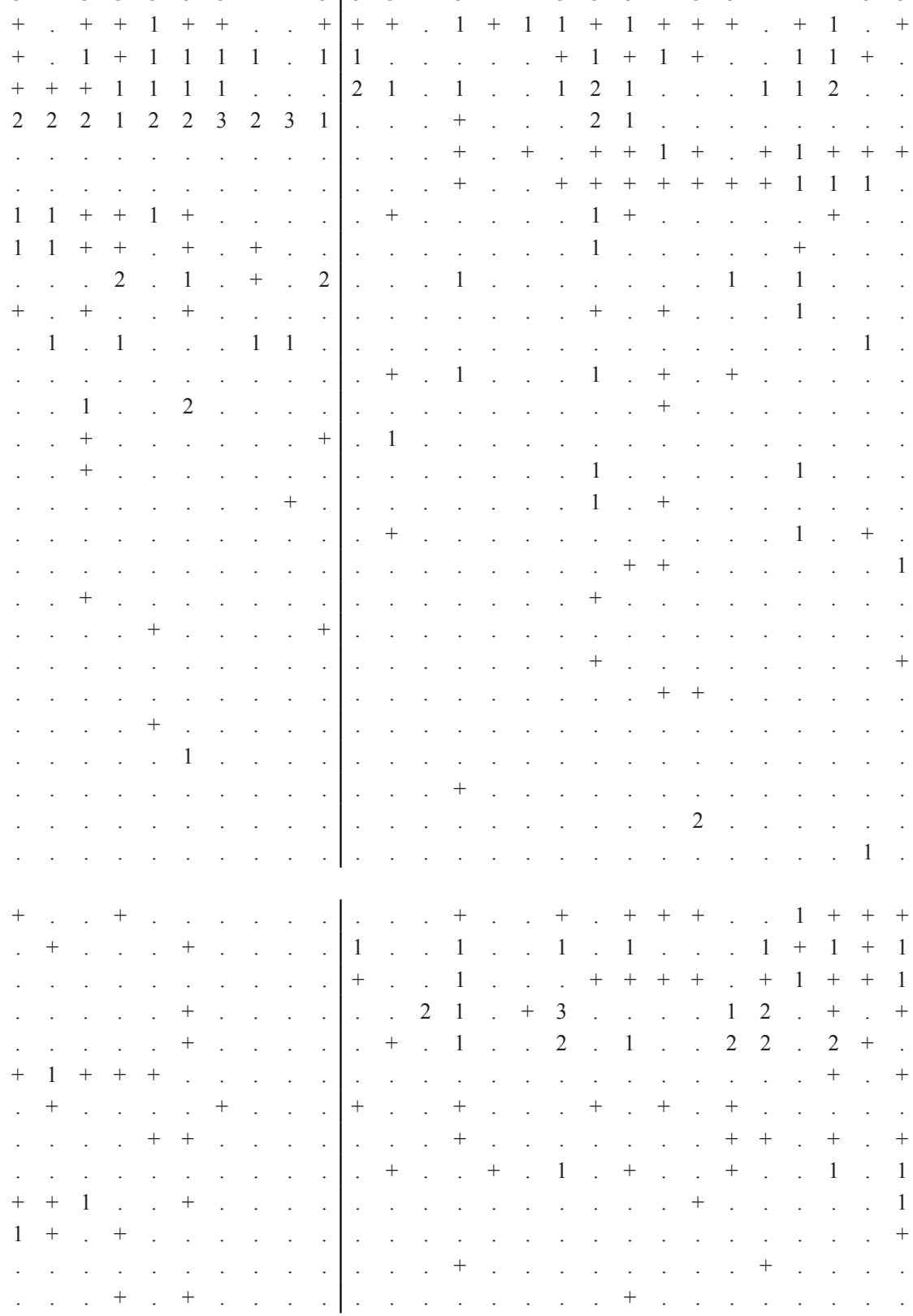
Asphodelus ramosus (T) (t)

Vulpia myuros

Trifolium angustifolium

Scorpiurus muricatus

Euphorbia falcata

Vulpia ciliata

Crupina crupinastrum

Sonchus tenerrimus

Lotus ornithopodioides

Convolvulus althaeoides

Euphorbia peplus

Arisarum vulgare

Sixalix atropurpurea

Melilotus sulcata

Dactylis glomerata

Other species

Hypericum perforatum

Sedum rupestre

Quercus ilex

Acinos arvensis

Crataegus monogyna

Fumana procumbens

Romulea bulbocodium

Carex halleriana

Poa bulbosa

Ostrya carpinifolia

Fraxinus ornus

Triticum ovatum

Filago pyramidata

Genista tinctoria

Sherardia arvensis

Orobanche teucrii

Sedum amplexicaule

Geranium columbinum

Dorycnium hirsutum

Cistus creticus

Erica multiflora

Crepis sancta

Euphorbia helioscopia

Tordylium apulum

Plantago lagopus

Nigella damascena

Picris hieracioides

Silene paradoxa

Echium vulgare

Gastridium ventricosum

Orobanche minor

Sesleria autumnalis

Minuartia mediterranea

Quercus pubescens

Anacamptis pyramidalis

Onopordum acanthium

Salvia verbenaca

Pistacia terebinthus
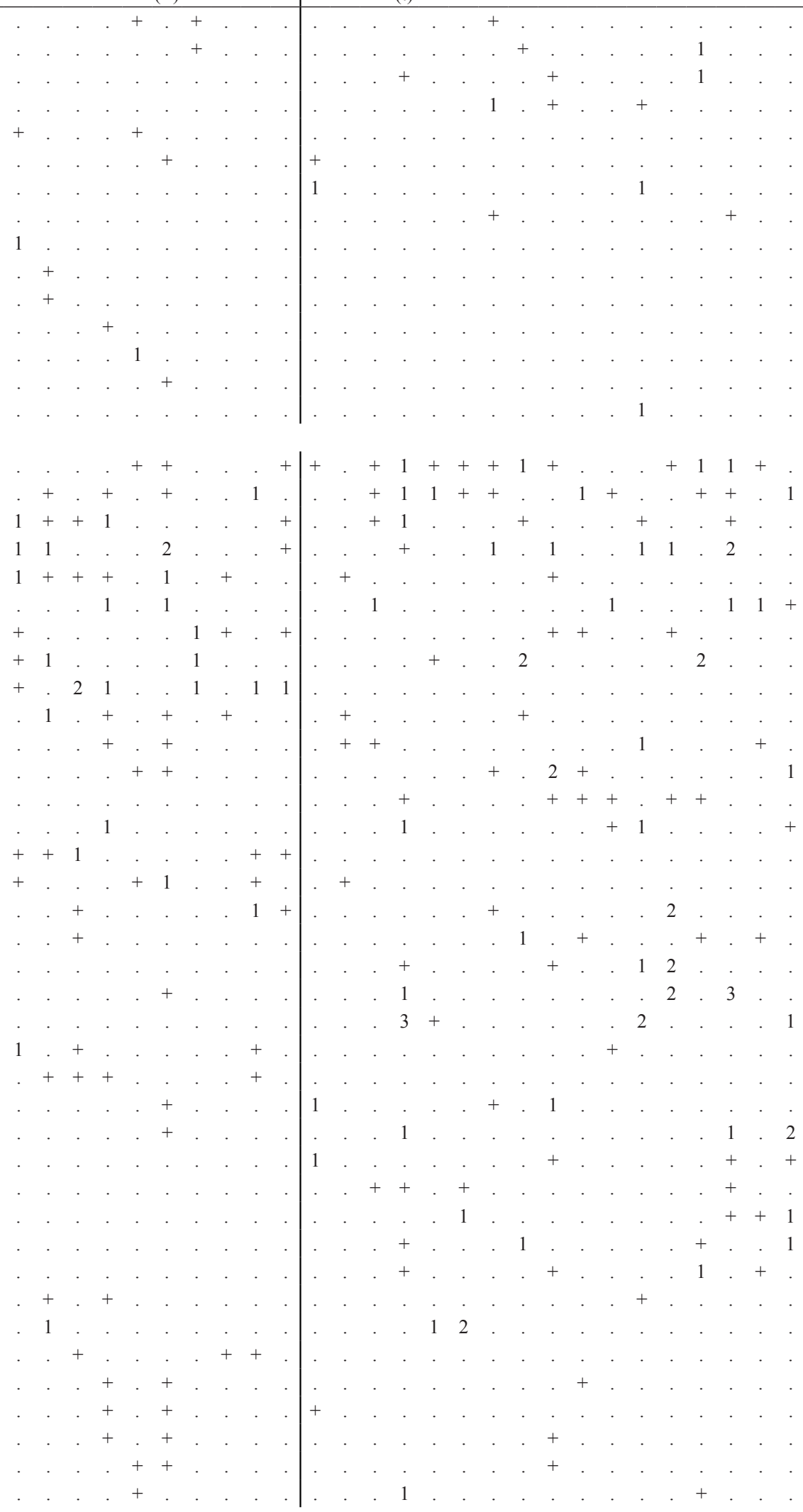


\begin{tabular}{|c|c|c|c|c|c|c|c|c|c|c|c|c|c|c|c|c|c|c|c|c|c|c|c|c|c|c|c|}
\hline Relevè nr. & 1 & 2 & 3 & 4 & 5 & $\begin{array}{c}6 \\
\text { (T) }\end{array}$ & 7 & 8 & 91 & & 111 & 12 & 13 & $\begin{array}{l}14 \\
\text { (t) }\end{array}$ & & & & & & & & & & & & & 27 \\
\hline Gladiolus italicus & . & . & . & . & . & . & . & . & . & & . & . & + & . & . & + & . & . & . & . & . & . & + & & . & . & . \\
\hline Galactites elegans & . & . & . & . & . & . & . & . & . & . & . & . & . & . & . & . & + & . & + & . & . & + & . & . & . & . & . \\
\hline Althaea hirsuta & . & . & . & . & . & . & . & . & . & . & . & . & . & + & . & . & 1 & . & . & . & . & . & . & . & . & . & + \\
\hline Rhamnus saxatilis & . & . & . & . & . & . & . & . & . & . & . & . & . & . & . & . & . & . & 1 & . & + & . & . & . & . & + & . \\
\hline Bombycilaena erecta & . & . & . & . & . & . & . & . & . & . & . & . & . & . & . & . & . & . & . & 1 & + & . & . & . & . & . & + \\
\hline Salvia officinalis & . & . & . & . & . & . & . & . & . & + & . & . & . & . & . & . & . & . & . & . & . & . & . & & 3 & . & . \\
\hline Cistus salviifolius & . & . & . & . & . & . & . & . & . & . & . & 1 & . & . & . & . & . & . & . & . & . & . & . & . & . & . & 1 \\
\hline Fumana arabica & . & . & . & . & . & . & . & . & . & . & . & . & . & . & . & . & . & . & . & . & . & 2 & . & . & . & . & 1 \\
\hline Cerastium luridum & + & . & . & + & . & . & . & . & . & . & . & . & . & . & . & . & . & . & . & . & . & . & . & . & . & . & . \\
\hline Clematis vitalba & + & . & . & . & . & . & . & . & . & + & . & . & . & . & . & . & . & . & . & . & . & . & . & . & . & . & . \\
\hline Crocus vernus albiflorus & . & + & . & + & . & . & . & . & . & . & . & . & . & . & . & . & . & . & . & . & . & . & . & . & . & . & . \\
\hline Viola pseudogracilis & . & + & . & . & . & 1 & . & . & . & . & . & . & . & . & . & . & . & . & . & . & . & . & . & . & . & . & . \\
\hline Anemone hortensis & . & . & + & . & + & . & . & . & . & . & . & . & . & . & . & . & . & . & . & . & . & . & . & . & . & . & . \\
\hline Anagallis arvensis & . & . & . & + & + & . & . & . & . & . & . & . & . & . & . & . & . & . & . & . & . & . & . & . & . & . & . \\
\hline Allium subhirsutum & . & . & . & + & 1 & . & . & . & . & . & . & . & . & . & . & . & . & . & . & . & . & . & . & . & . & . & . \\
\hline Rosa canina & . & . & . & + & . & . & . & . & . & . & . & . & . & . & . & . & . & . & . & . & . & . & . & + & . & . & . \\
\hline Calicotome villosa & . & . & . & 1 & . & . & + & . & . & . & . & . & . & . & . & . & . & . & . & . & . & . & . & . & . & . & . \\
\hline Saxifraga tridactylites & . & . & . & . & . & . & . & + & + & . & . & . & . & . & . & . & . & . & . & . & . & . & . & . & . & . & . \\
\hline Thalictrum minus & . & . & . & . & . & . & . & . & . & + & . & . & . & . & . & . & . & . & . & . & 1 & . & . & . & . & . & . \\
\hline Stachys officinalis & . & . & . & . & . & . & . & . & . & . & . & + & . & + & . & . & . & . & . & . & . & . & . & . & . & . & . \\
\hline Trifolium lappaceum & . & . & . & . & . & . & . & . & . & . & . & . & . & + & . & . & . & . & . & . & . & . & + & & . & . & . \\
\hline Arenaria serpyllifolia & . & . & . & . & . & . & . & . & . & . & . & . & + & . & . & . & . & . & . & . & . & . & . & + & . & . & . \\
\hline Lolium perenne & . & . & . & . & . & . & . & . & . & . & . & . & . & + & . & . & . & . & + & . & . & . & . & . & . & . & . \\
\hline Pistacia lentiscus & . & . & . & . & . & . & . & . & . & & . & . & . & + & . & . & . & . & . & . & . & 1 & . & . & . & . & . \\
\hline Spartium junceum & . & . & . & . & . & . & . & . & . & . & . & . & . & . & . & . & + & . & . & . & . & + & . & . & . & . & . \\
\hline Silene vulgaris & . & . & . & . & . & . & . & . & . & & . & . & . & . & . & . & + & . & . & . & . & . & . & . & . & . & + \\
\hline Centaurea solstitialis & . & . & . & . & . & . & . & . & . & & . & . & . & . & . & . & . & . & + & . & . & . & . & . & . & . & 1 \\
\hline Cerastium brachypetalum & . & . & . & . & . & . & . & . & . & & . & . & . & . & . & . & . & . & . & + & + & . & . & . & . & . & . \\
\hline Geranium dissectum & . & . & . & . & . & . & . & . & . & & . & . & . & . & . & . & . & . & . & + & + & . & . & . & . & . & . \\
\hline Biscutella didyma & . & . & . & . & . & . & . & . & . & & . & . & . & . & . & . & . & . & . & . & . & + & + & . & . & . & . \\
\hline Genista januensis & . & . & . & . & . & . & . & . & . & & . & . & . & . & . & . & . & . & . & . & + & . & . & . & . & . & . \\
\hline
\end{tabular}

CAPTION: c: characteristic; rc: regional character.; pc: partial character., t: transgressive; i: ingressive 
Table 3: Synoptic table of the main dry grassland associations of Peninsular Italy.

Tabela 3: Sinoptična tabela glavnih asociacij suhih travišč Italijanskega polotoka.

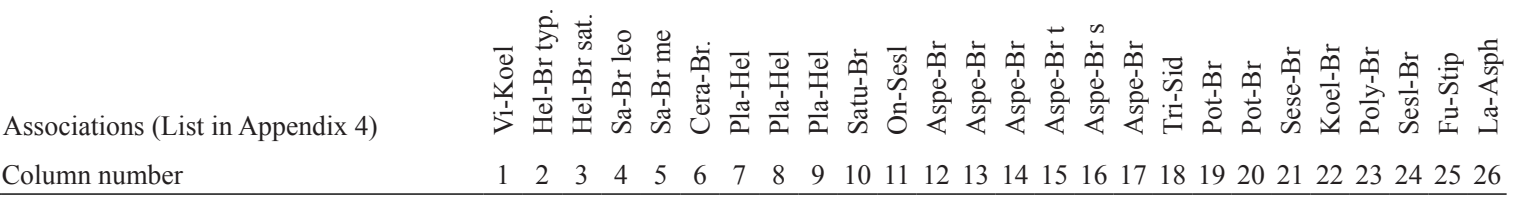

Violo-Koelerietum splendentis

Spc Viola pseudogracilis

CBt Festuca stricta

Src Carex humilis

AB Seseli montanum

$\mathrm{CBc}$ Thymus striatus

Helichryso-Brometum erecti

PBi Helichrysum italicum

$\mathrm{CBc}$ Centaurea deusta

$\mathrm{PBc}$ Centaurium erythraea

$\mathrm{PBc}$ Melica transsilvanica

PBi Micromeria graeca

Sedum sexangulare

Cerastio etrusci-Brometum erecti

Cerastium arvense

Marrubium incanum

Alyssum minus

Carlina corymbosa

Plantago holostei-Helianthemetum cani

$\mathrm{CBt}$ Plantago holosteum

St Helianthemum oelandicum

Saturejo montanae-Brometum erecti

$\mathrm{AB}$ Satureja montana

$\mathrm{AB}$ Plantago sempervirens

$\mathrm{CBi}$ Cytisus spinescens

$\mathrm{CBc}$ Sideritis italica

$\mathrm{CBt}$ Globularia bisnagarica

Onobrychido albae-Seslerietum nitidae

Sc Onobrychis alba

$\mathrm{CBc}$ Centaurea ambigua

$\mathrm{CBc}$ Sesleria nitida

Asperulo purpureae-Brometum erecti

$\mathrm{AB}$ Asperula purpurea

$\mathrm{CBc}$ Erysimum pseudorhaeticum

$\mathrm{PBc}$ Coronilla minima

$\mathrm{AB}$ Artemisia alba

$\begin{aligned} & \text { Stachys recta } \\ \mathrm{PBc} & \text { Dianthus ciliatus }\end{aligned}$
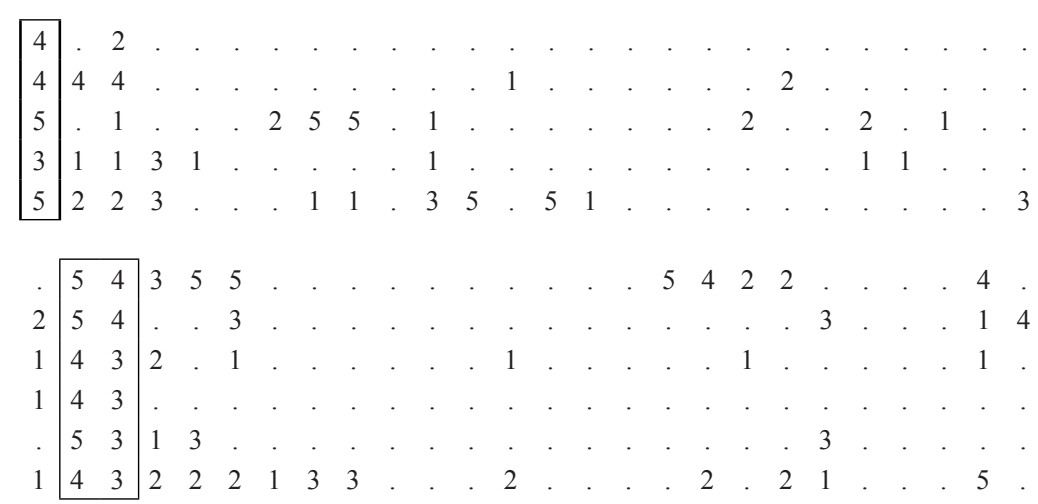

Trigonello monspeliacae-Sideritidetum syriacae

$\mathrm{PBt}$ Trigonella gladiata

PBt Trigonella monspeliaca

PBt Ononis reclinata

Potentillo cinereae-Brometum erecti

Src Potentilla incana

$\mathrm{AB}$ Alyssum montanum

AB Cyanus triumfetti

CBrc Minuartia verna
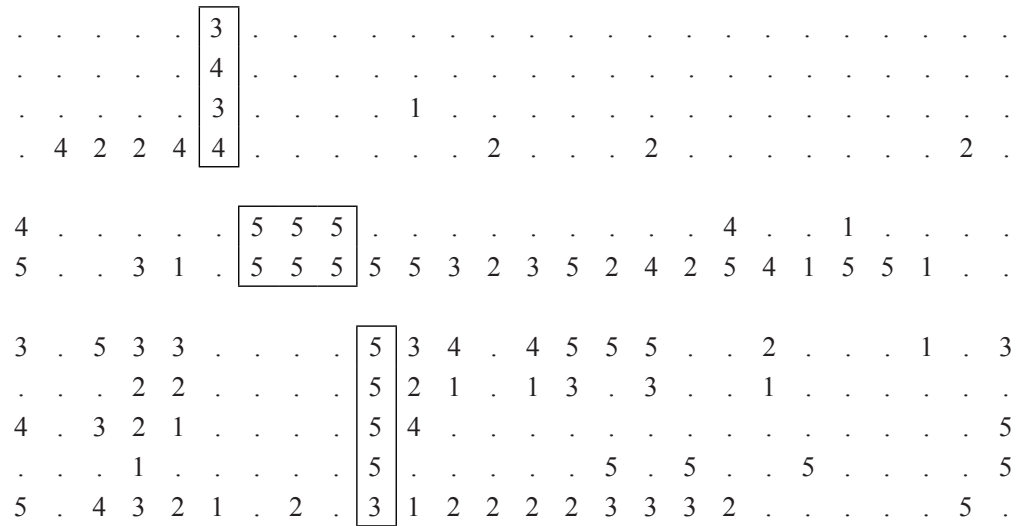

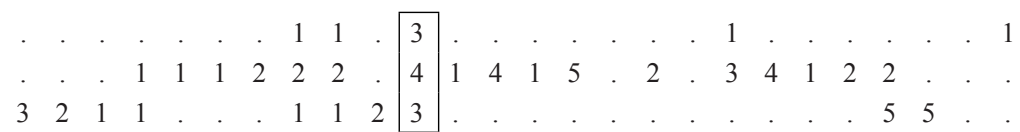
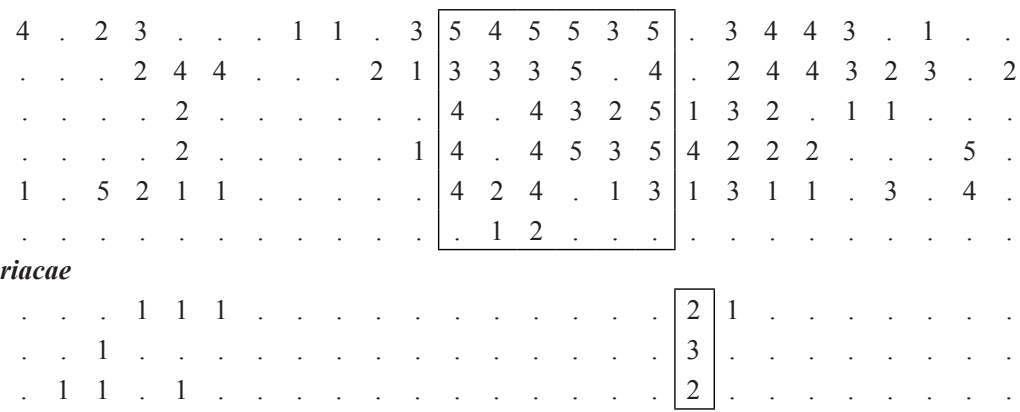

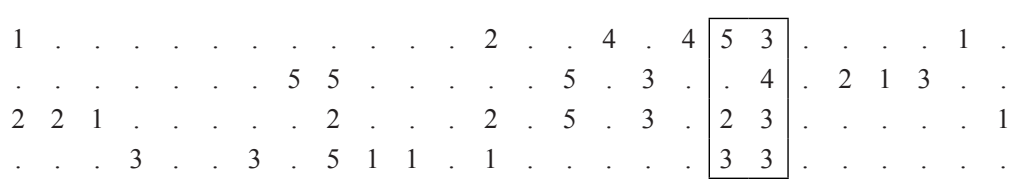


Column number

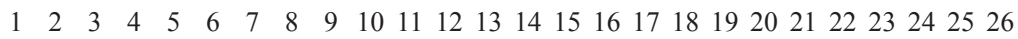

Seseli viarii-Brometum erecti

CBrc Seseli pallasii

Euphorbia nicaeensis

Koelerio splendentis-Brometum erecti

Src Valeriana tuberosa

Pedicularis comosa

Gentianella columnae

Trifolium alpestre

Polygalo majoris-Brometum erecti

$\mathrm{AB}$ Biscutella laevigata

$\mathrm{CBc}$ Laserpitium siler

Seslerio nitidae-Brometum erecti

$\mathrm{CBc}$ Carex macrolepis

$\mathrm{Si}$ Festuca laevigata

Cytisus hirsutus

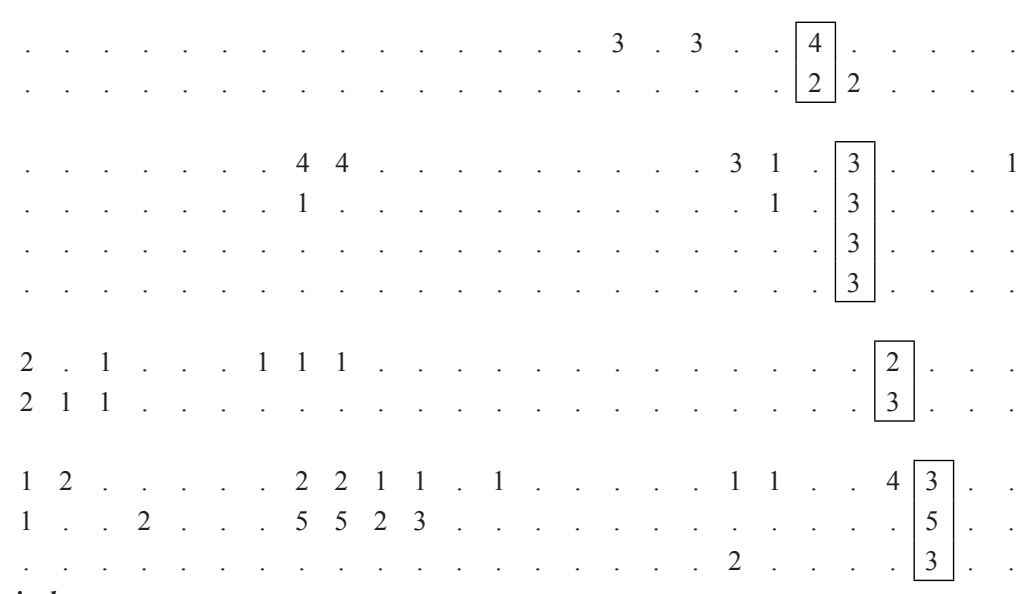

Fumano procumbentis-Stipetum appenninicolae

$\mathrm{CBc}$ Stipa dasyvaginata

Fumana procumbens

$\begin{array}{lllll}1 & . & 1 & 1 & 1\end{array}$

$\begin{array}{llllll}1 & 2 & 2 & 3 & 2 & 1\end{array}$

Lavandulo angustifoliae-Asphodelinetum luteae

$\mathrm{CBc}$ Asphodeline lutea

Lavandula angustifolia

Leontodon crispus

\begin{tabular}{lllllllllllllllllllllllll|l|}
. & 1 &. &. &. & 1 &. &. &. &. &. &. &. &. &. &. &. &. &. &. &. &. &. &. & 3 & 5 \\
. &. &. &. &. &. &. &. &. &. &. &. &. &. &. &. &. &. &. &. &. &. &. &. & & 5 \\
3 & 2 & 2 & 5 & 1 &. &. &. & 3 &. &. &. &. &. &. &. &. &. &. &. &. &. &. &. &. & 5 \\
\hline
\end{tabular} suballiance: Phleo ambigui-Bromenion erecti

$\mathrm{PBc}$ Ononis pusilla

PBc Crupina vulgaris

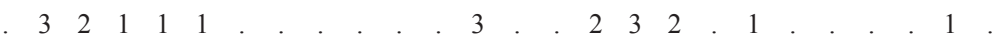

$\mathrm{PBc}$ Melica ciliata

$\mathrm{PBc}$ Cephalaria leucantha

$\mathrm{PBc}$ Crepis neglecta

$\mathrm{PBc}$ Hieracium cymosum

$\mathrm{PBc}$ Linum bienne

$\mathrm{PBc}$ Allium tenuiflorum

$\mathrm{PBc}$ Silene paradoxa

$\mathrm{PBc}$ Trifolium strictum

$\mathrm{PBc}$ Carex flacca

$\mathrm{PBc}$ Convolvulus cantabrica

PBt Petrorhagia saxifraga

PBt Bupleurum baldense

PBt Reichardia picroides

PBt Eryngium campestre

PBt Cynosurus echinatus

PBt Urospermum dalechampii

PBt Linum strictum

PBt Medicago minima

PBt Avena barbata

PBt Sideritis romana

PBt Brachypodium retusum

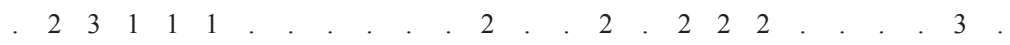

PBt Briza maxima

PBi Teucrium capitatum

PBi Triticum ovatum

suballiance: Sideritidenion italicae

Sc Avenula praetutiana

Sc Potentilla rigoana

Sc Trinia dalechampii

Sc Brachypodium genuense

$\begin{array}{lllllllllllllllllllllllll}\cdot & . & . & . & 2 & 2 & . & . & . & . & . & 2 & . & 2 & 1 & 1 & 1 & 1 & . & 1 & . & . & . & \cdot & \cdot \\ . & 1 & 3 & 1 & 1 & . & . & . & . & . & . & . & 1 & . & . & . & . & . & 1 & . & . & . & . & . & 2\end{array}$.

$\begin{array}{lllllllllllllllllll}1 & 2 & 1 & 2 & 3 & . & . & . & . & . & . & . & . & .\end{array}$

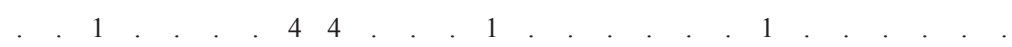

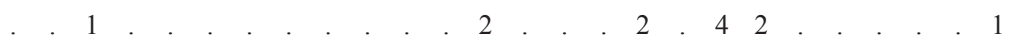

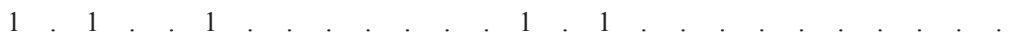

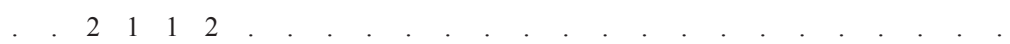

$11 . .1$

. 32 . .

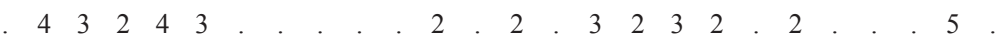

$\begin{array}{lllllllllllllllllllllllllllllll}2 & . & 2 & 3 & 4 & 1 & . & . & . & 4 & 2 & 4 & 1 & 4 & . & 2 & 1 & 2 & 2 & 4 & . & . & & 5 & 1\end{array}$

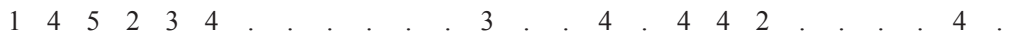

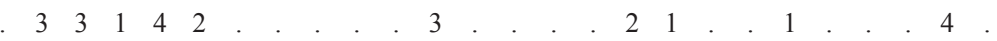

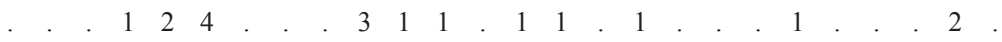

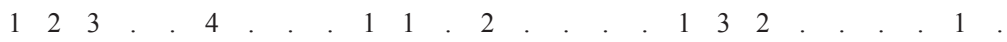

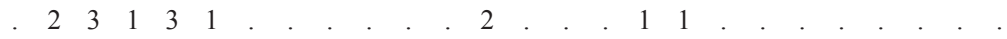

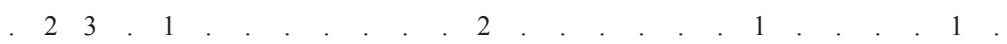

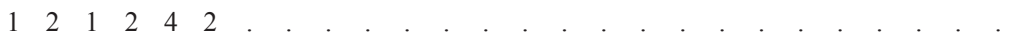

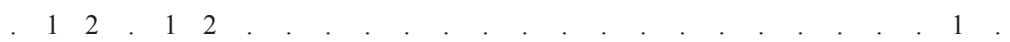

. 2.12 . . . . . . . . . . . . . 1 .

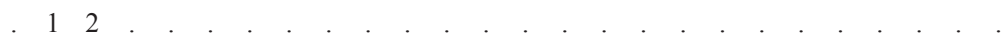

\begin{tabular}{lllllllllllllllllll}
\hline & 2 &. &. &. &. &. &. &. &. &. &. &. &. &. &.
\end{tabular}

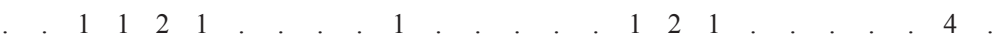

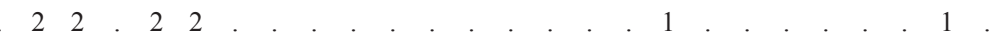

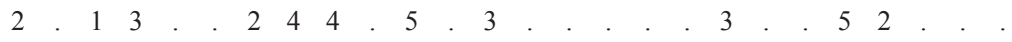

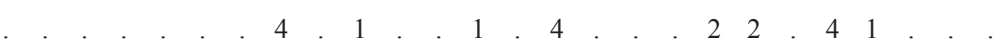

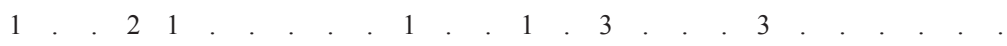

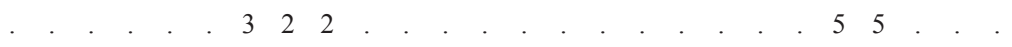




\begin{tabular}{|c|c|c|c|c|c|c|c|c|c|c|c|c|c|c|c|c|c|c|c|c|c|c|c|c|c|c|}
\hline & Column number & 1 & 2 & 3 & 4 & 5 & 6 & 7 & 8 & 9 & 10 & 11 & 12 & 131 & 14 & 151 & 161 & & & & 21 & 22 & 23 & 242 & & 26 \\
\hline $\mathrm{Sc}$ & Veronica orsiniana & . & . & . & 1 & . & . & . & . & . & . & . & . & 1 & & . & . & & 1 & 1 & . & . & . & . & . & \\
\hline $\mathrm{Sc}$ & Anthemis cretica & . & . & . & . & . & . & . & 5 & 5 & . & . & . & . & . & . & . & . & . & . & . & . & . & . & . & \\
\hline $\mathrm{Sc}$ & Allium flavum & 1 & . & . & . & . & . & . & . & . & . & . & . & . & . & . & . & . & . & . & . & . & . & . & . & \\
\hline $\mathrm{Sc}$ & Rhinanthus wettsteinii & . & . & . & . & . & . & . & . & . & . & 1 & . & . & . & . & . & . & . & 1 & . & . & . & . & & \\
\hline Src & Armeria canescens & . & . & . & 1 & 1 & 1 & . & 1 & 2 & 2 & 2 & . & 2 & . & . & . & . & . & 2 & . & 5 & 1 & . & . & 3 \\
\hline Src & Gymnadenia conopsea & 1 & . & . & . & . & . & . & 1 & 2 & . & . & . & 2 & . & . & . & . & . & 1 & . & 1 & 2 & . & . & \\
\hline Src & Plantago argentea & 1 & . & . & . & . & . & . & 4 & 4 & . & 1 & . & . & . & . & . & . & 1 & . & . & 3 & . & . & . & . \\
\hline St & Cerastium arvense & 1 & 1 & . & 2 & 2 & . & 2 & 3 & 3 & . & . & 1 & 4 & . & . & . & 3 & . & 4 & 2 & 3 & 4 & 4 & . & . \\
\hline $\mathrm{Si}$ & Acinos alpinus & 2 & 2 & 3 & 4 & 3 & 1 & . & 5 & 5 & . & 1 & 2 & . & 2 & 3 & 2 & 4 & 1 & 2 & 3 & 4 & 2 & 1 & . & 2 \\
\hline $\mathrm{Si}$ & Globularia meridionalis & 2 & . & . & 2 & 1 & . & 2 & 5 & 5 & 5 & 3 & . & . & . & . & . & . & . & 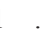 & . & 5 & 2 & . & . & . \\
\hline $\mathrm{Si}$ & Anthyllis montana & 1 & . & . & . & . & . & 1 & 5 & 5 & . & 2 & . & . & . & . & . & . & . & 1 & . & 4 & 4 & . & . & . \\
\hline $\mathrm{Si}$ & Paronychia kapela & 1 & . & . & 1 & . & . & 1 & 5 & 5 & . & . & . & . & . & . & . & . & . & . & . & 1 & 2 & . & . & . \\
\hline $\mathrm{Si}$ & Draba aizoides & . & . & . & . & . & . & 3 & 2 & 2 & . & . & . & . & . & . & . & . & . & . & . & 1 & 1 & . & . & \\
\hline $\mathrm{Si}$ & Sesleria juncifolia & 2 & . & . & . & . & . & 1 & . & . & . & 1 & . & . & . & . & . & . & . & 1 & . & . & . & . & . & . \\
\hline $\mathrm{Si}$ & Thymus praecox & . & . & . & . & . & . & . & . & . & . & . & . & 2 & . & . & . & . & . & 2 & . & . & . & . & . & . \\
\hline $\mathrm{Si}$ & Edraianthus graminifolius & 2 & . & . & . & . & . & 3 & . & . & . & . & . & . & . & . & . & . & . & . & . & . & . & . & . & \\
\hline $\mathrm{Si}$ & Lomelosia crenata & . & . & . & . & . & . & . & . & . & . & . & . & . & . & . & . & . & . & . & 1 & . & . & . & . & \\
\hline $\mathrm{Si}$ & Cerastium tomentosum & . & . & . & . & . & . & . & . & . & 4 & 4 & . & . & . & . & . & & . & . & . & . & . & . & & 3 \\
\hline
\end{tabular}

\section{alliance: Cytiso spinescentis-Bromion erecti; suborder: Festuco-Seslerienalia nitidae}

$\mathrm{CBc}$ Phleum hirsutum

$\mathrm{CBc}$ Crepis lacera

$\mathrm{CBc}$ Festuca inops

CBpc Festuca stricta

CBrc Thlaspi praecox

CBrc Orchis pauciflora

CBrc Ruta graveolens

CBrc Potentilla pedata

$\mathrm{CBc}$ Leontodon cichoraceus

$\mathrm{CBc}$ Polygala flavescens

$\mathrm{CBc}$ Centaurea rupestris

$\mathrm{CBc}$ Scabiosa holosericea

$\mathrm{CBc}$ Elaeoselinum asclepium

$\mathrm{CBc}$ Potentilla detommasii

CBi Onosma echioides

$\mathrm{CBi}$ Euphorbia spinosa

CBpc Ornithogalum etruscum

$\mathrm{CBpc}$ Asphodeline liburnica

CBpc Ornithogalum exscapum

CBpc Sesleria apennina

$\mathrm{CBrc}$ Helianthemum apenninum

CBrc Argyrolobium zanonii

CBrc Tragopogon samaritani

CBrc Ranunculus illyricus

CBrc Euphorbia myrsinites

CBrc Alyssum diffusum

CBrc Pimpinella tragium

$\mathrm{CBt}$ Galium corrudifolium

CBt Aethionema saxatile

$\mathrm{CBt}$ Asperula aristata

CBt Ranunculus millefoliatus

$\begin{array}{llllllllllllllllllllllllll}2 & . & 2 & 3 & 4 & 5 & . & 4 & 4 & 2 & 2 & 3 & 5 & 3 & 5 & 3 & 3 & 3 & 4 & 3 & 5 & 2 & 2 & . & 1 & 4\end{array}$ $\begin{array}{lllllllllllllllllllllllllll}2 & 2 & 3 & 2 & 1 & 1 & . & . & . & . & & 3 & 4 & 3 & 4 & 1 & 5 & 1 & 2 & 4 & 4 & . & 1 & . & .\end{array}$

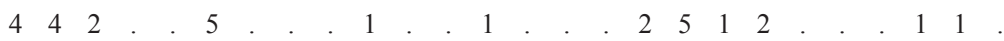

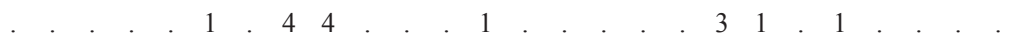

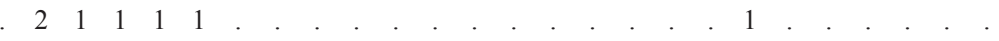

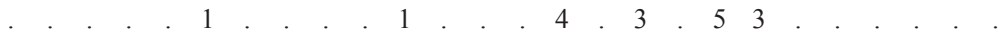

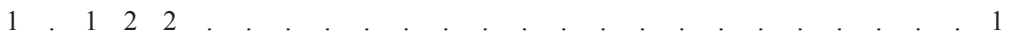

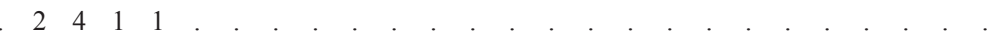

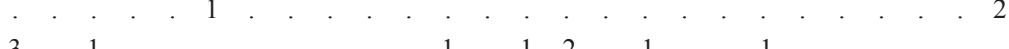

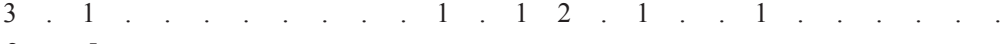
2.5 $\begin{array}{llllll}2 & 1 & 2 & 1 & . & 1\end{array}$ . . . . . . . . . . . 2 2

1

$\begin{array}{lllllllllllllllllllllllllllllllllll}1 & . & 1 & 2 & . & 1 & . & 1 & 1 & 1 & 1 & 2 & . & 2 & . & 4 & . & 4 & 3 & 2 & . & . & . & . & . & 1\end{array}$

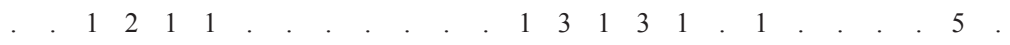
$\begin{array}{lllll}3 & 1 & 2 & 1 & 1\end{array}$

Order: Artemisio albae-Brometalia erecti Koeleria splendens Hippocrepis comosa $\begin{array}{llllllllllllllllllllllllll}5 & 4 & 5 & 4 & 2 & 3 & 2 & 5 & 5 & 3 & 4 & 3 & 4 & 3 & 4 & . & 4 & 3 & 5 & 5 & 5 & 4 & 4 & 4 & 1 & 4\end{array}$ Teucrium chamaedrys 
Column number

Muscari neglectum

Dianthus sylvestris

Brachypodium rupestre

Allium sphaerocephalon

Eryngium amethystinum

Helianthemum nummularium

Festuca circummediterranea

Asperula cynanchica

Silene otites

Knautia purpurea

Galium lucidum

Linum tenuifolium

Thesium humifusum

Teucrium montanum

Anthyllis vulneraria

Anthyllis vulneraria

Arabis collina

Bunium bulbocastanum

Scabiosa columbaria

Trinia glauca

Inula montana

Carlina acaulis

Hieracium piloselloides

Polygala major

Cota tinctoria

Arabis sagittata

Ophrys apifera

Petrorhagia prolifera

Ononis spinosa

Orchis tridentata

Pseudolysimachion barrelieri

Inula hirta

Narcissus poeticus

Orchis anthropophora

Koeleria cristata

Ophrys holoserica

Anthyllis vulneraria

Anthericum liliago

Echinops ritro

Polygala niceensis

Dorycnium pentaphyllum

Astragalus monspessulanum

Class: Festuco-Brometea

Bromus erectus

Thymus longicaulis

Hieracium pilosella

Lotus corniculatus

Sanguisorba minor

Medicago lupulina

Carex caryophyllea

Dactylis glomerata

Trifolium campestre

Arabis hirsuta

Plantago lanceolata

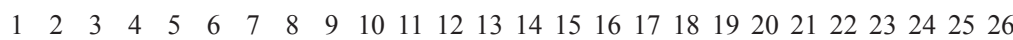

$\begin{array}{llllllllllllllllllllllllll}3 & 2 & 1 & 2 & 1 & . & . & 4 & 4 & 2 & . & 1 & 3 & 1 & 2 & 3 & 1 & 3 & 5 & 4 & 3 & 2 & . & . & 1 & 1\end{array}$

$\begin{array}{lllllllllllllllllllllll}1 & . & 3 & 2 & 1 & 3 & . & 5 & 5 & . & 1 & 3 & 2 & 3 & 5 & 2 & 4 & 2 & 2 & 4 & 4 & 3 & 2\end{array}$

$\begin{array}{llllllllllllllllllllllllll}1 & 1 & 1 & 2 & 2 & 2 & . & . & . & 3 & 1 & 5 & 4 & 5 & 5 & 2 & 5 & 2 & 2 & 3 & 1 & . & 4 & 4 & 1\end{array}$.

$\begin{array}{llllllllllllllllllllllllll}2 & 1 & 1 & 1 & 2 & 4 & . & . & . & 3 & . & 3 & 1 & 3 & 5 & 1 & 3 & 1 & 3 & 3 & 1 & . & 2 & 3\end{array}$.

$\begin{array}{llllllllllllllllllllllllllllllllll}3 & 3 & 5 & 3 & 4 & 2 & . & 5 & 5 & 3 & 1 & 5 & 5 & 5 & 5 & 3 & 5 & 3 & 5 & 5 & 4 & 1 & . & . & .\end{array}$

$\begin{array}{lllllllllllllllllllllllll}3 & 5 & 4 & 3 & 3 & 1 & . & . & . & 1 & 1 & 1 & 4 & 1 & 3 & . & 1 & 1 & 2 & 3 & . & 1 & 2 & . & 5\end{array}$.

$\begin{array}{lllllllllllllllllllllllllll}2 & 4 & 3 & 5 & 3 & . & 4 & 4 & 4 & 2 & 3 & . & 3 & . & . & . & . & 3 & 3 & 3 & 2 & 2 & & 2 & 4\end{array}$

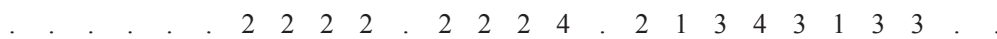

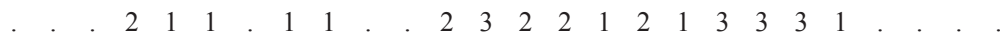

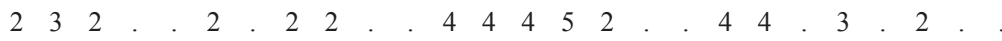

$\begin{array}{lllllllllllllllllllllllll}1 & 2 & 1 & 4 & 3 & . & . & 4 & 4 & 2 & . & . & . & . & . & 3 & 5 & . & 4 & 4 & 5 & 5 & 5\end{array}$.

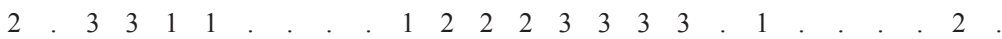

$\begin{array}{lllllllllllllllllllllllllllllllllllllll}3 & 1 & 4 & 3 & 1 & 2 & . & . & . & . & 1 & 4 & 2 & 4 & 1 & 1 & 3 & 1 & 1 & 1 & . & . & . & .\end{array}$

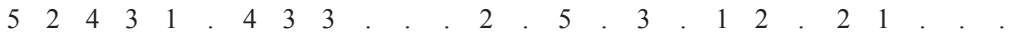

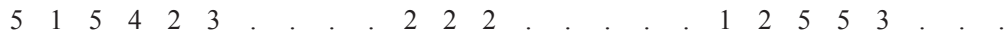

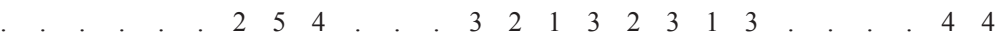

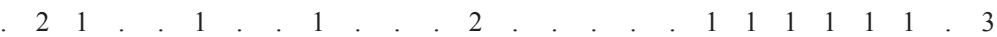

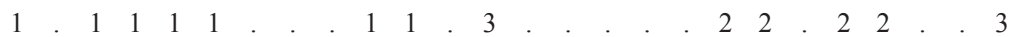

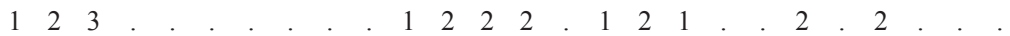

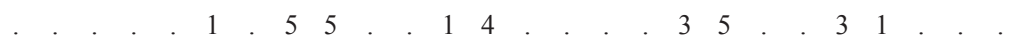

$1 . \quad 2 \quad 22$. . . 1 . 2 . . . . 21 . . .

. . 1.2 . . . . 2 . . . . 2 . 2 . 2 . 2 . 1

$1.1 . .2$. . . . 2 . . 2 . . . . . .

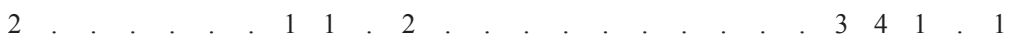

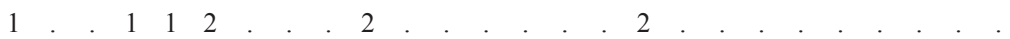

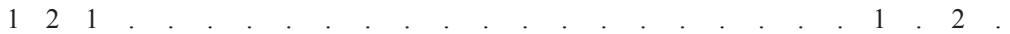

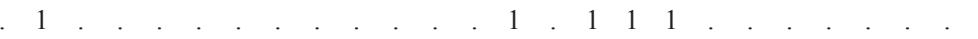

. . 3 . 1 . . . . . . . 13 . . .

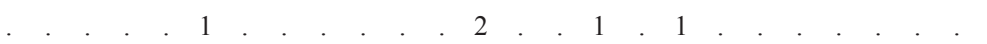

11.11 . . . . . . . . . . . . . . . .

1 . . . . . . . . . . . . . . .

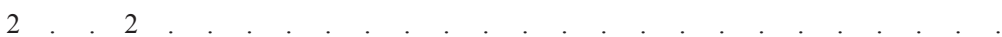

12

11

. . . . . . . . . . . . . . . 3

. $1 . .1$
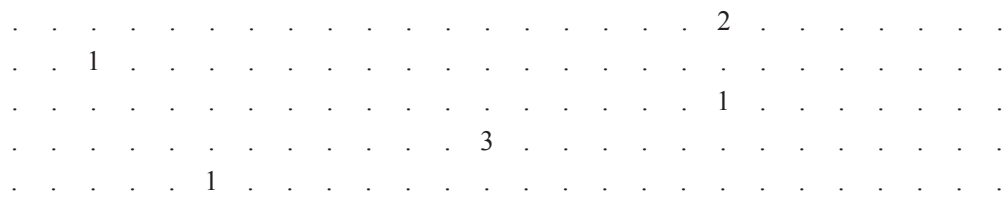

$\begin{array}{llllllllllllllllllllllllll}4 & 5 & 5 & 5 & 5 & 5 & 3 & 5 & 5 & 3 & 5 & 5 & 5 & 5 & 5 & 5 & 5 & 5 & 5 & 5 & 5 & 5 & 5 & 5 & 5 & 5\end{array}$

$\begin{array}{llllllllllllllllllllllllll}3 & 5 & 1 & 3 & 4 & 5 & 5 & 2 & 2 & . & 1 & 4 & 5 & 4 & 5 & 5 & 4 & 5 & 4 & 4 & 3 & 5 & 3 & 2 & 5 & 1\end{array}$

$\begin{array}{lllllllllllllllllllllllll}1 & 2 & 1 & 5 & 2 & 1 & 4 & 3 & 3 & 3 & . & 4 & 5 & 4 & 5 & . & 5 & 1 & 5 & 4 & . & 5 & 4 & 3 & 3\end{array}$.

$\begin{array}{lllllllllllllllllllllllllll}1 & 4 & 1 & 3 & 1 & 2 & . & 1 & 1 & 2 & 2 & 2 & 5 & 2 & 5 & 2 & 5 & 2 & 3 & 4 & 2 & 3 & 4 & 1 & 2\end{array}$

$\begin{array}{llllllllllllllllllllllllll}2 & 5 & 3 & 5 & 5 & 5 & . & 3 & . & 3 & 4 & 3 & 4 & 3 & 5 & 4 & 5 & 4 & 5 & 5 & 4 & 2 & 2 & . & 4 & 2\end{array}$

$\begin{array}{llllllllllllllllllllllllll}1 & 4 & 2 & 3 & 2 & 1 & 2 & 1 & 1 & . & . & 1 & 2 & 1 & . & 2 & 1 & 2 & 1 & . & 3 & 2 & 1 & . & . & 1\end{array}$

$\begin{array}{llllllllllllllllllllllllllllllllllll}1 & 3 & 1 & 3 & 1 & 1 & . & 4 & 4 & . & 2 & 1 & 2 & 4 & 1 & 4 & 1 & 3 & 3 & & 5 & . & .\end{array}$

$\begin{array}{llllllllllllllllllllllll} & 4 & 3 & 2 & 5 & 5 & . & 1 & . & 2 & . & 4 & 2 & 4 & 2 & 3 & 4 & 2 & & 1 & 2 & . & . & .\end{array}$

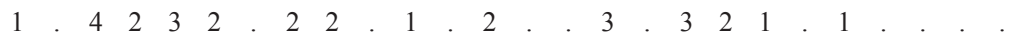

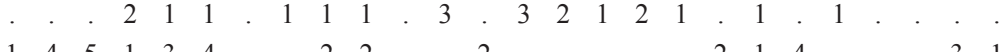

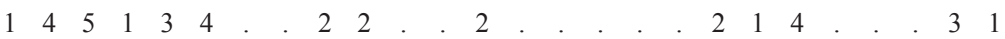


Column number

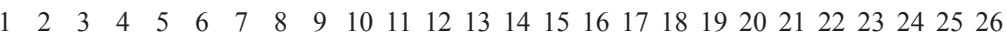

Euphrasia stricta

Euphorbia cyparissias

Ranunculus bulbosus

Orchis morio

Trifolium ochroleucum

Onobrychis viciifolia

Knautia arvensis

Tanacetum corymbosum

Leontodon hispidus

Trifolium montanum

Carduus nutans

Linum catharticum

Campanula glomerata

Centaurea jacea

Cerastium arvense

Cerastium ligusticum

Herniaria glabra

Anacamptis pyramidalis

Achillea millefolium

Bromus hordeaceus

Prunella laciniata

Anthemis arvensis

Avenula pratensis

Achillea collina

Geranium pyrenaicum

Dactylorhiza sambucina

Potentilla tabernaemontani

Potentilla recta

Dianthus carthusianorum

Pimpinella saxifraga

Salvia pratensis

Crocus vernus

Rhinanthus alectorolophus

Filipendula vulgaris

Stachys germanica

Briza media

Campanula rapunculus

Plantago media

Leucanthemum vulgare

Crocus biflorus

Daucus carota

Euphrasia salisburgensis

Orchis mascula

Linum viscosum

Thymus pulegioides

Sanguisorba minor

Parentucellia viscosa

Parentucellia latifolia

Achillea setacea

Orchis purpurea

Thesium linophyllon

Jasione montana

Orchis coriophora

Phleum bertolonii

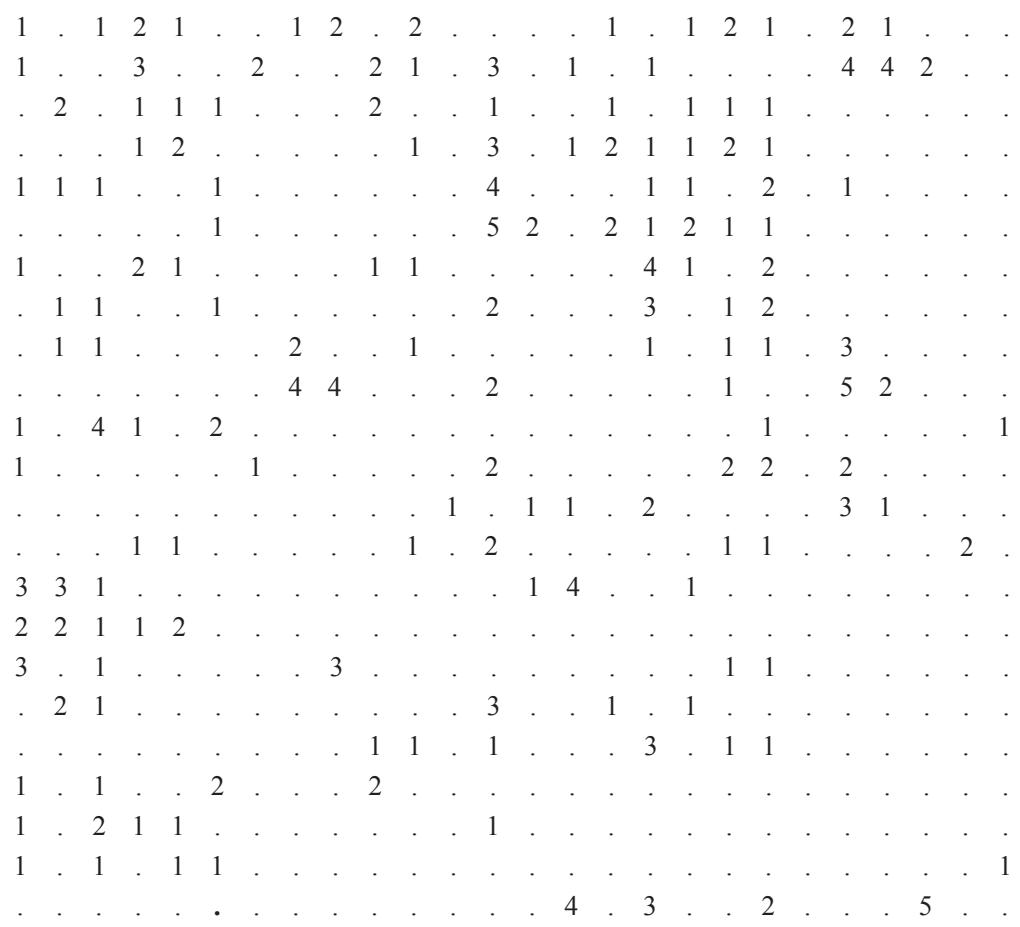


Cisto-Micromerietea / Rosmarinetea

Cistus creticus

Genista januensis

Genista tinctoria

Dorycnium hirsutum

Erica multiflora

Cistus salviifolius

Fumana arabica

Salvia officinalis

Fumana thymifolia

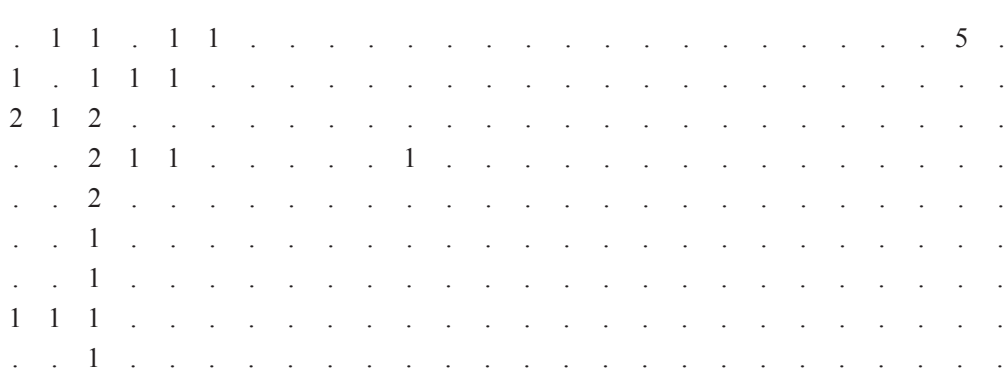

Elyno-Seslerietea / Nardetea / Thlaspietea rot.

Carlina acanthifolia

Poa alpina

Astragalus depressus

Minuartia verna

Carum flexuosum

Myosotis alpestris

Poa molinerii

Ranunculus oreophilus

Anthyllis vulneraria

Cardus carlinaefolius

Alchemilla glaucescens

Androsace villosa

Carex kitaibeliana

Festuca trichophylla

Galium magellense

Gentiana lutea

Gentiana utriculosa

Gentiana verna

Hutchinsia alpina

Leontodon montanus

Pedicularis elegans

Polygala alpestris

Robertia taraxacoides

Sedum atratum

Arctostaphylos uva-ursi

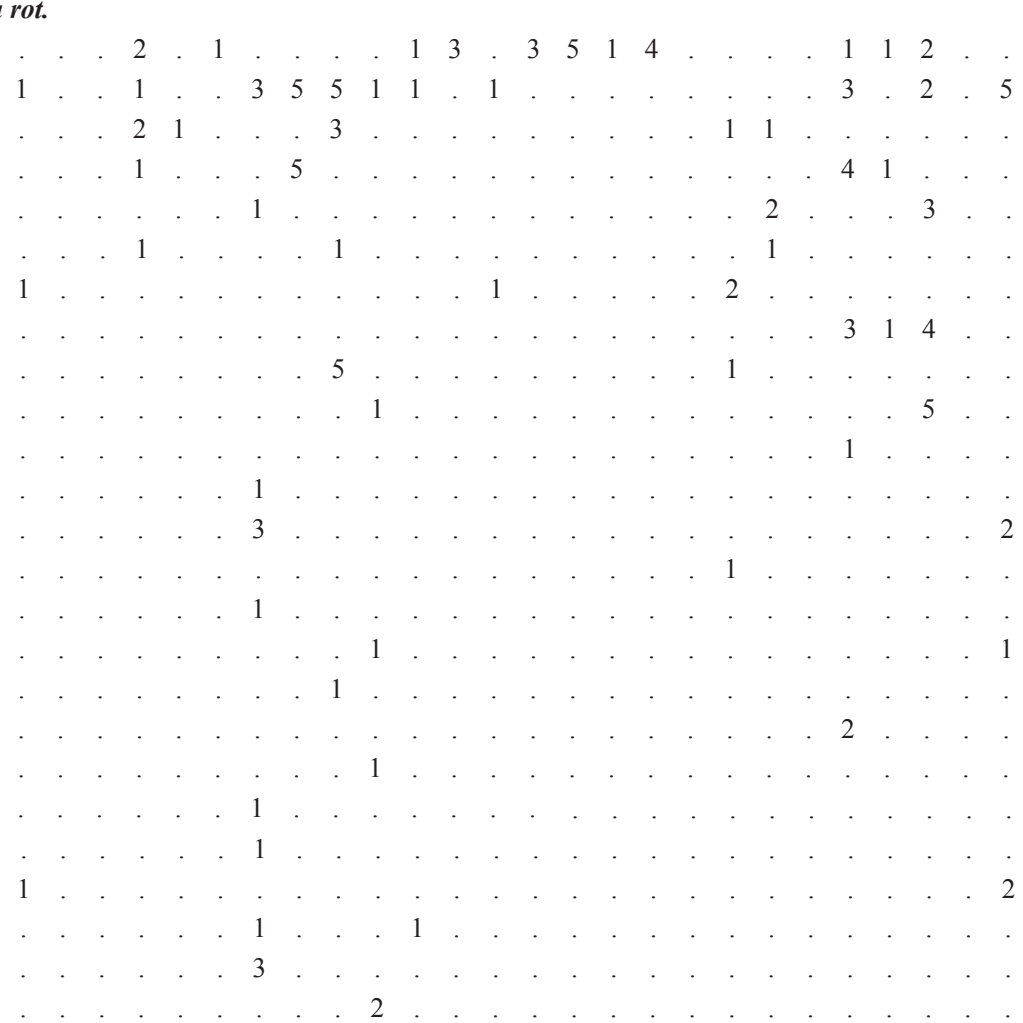

Lygeo-Stipetea/Thero-Brachypodietea

Ampelodesmos mauritanicus

Asphodelus ramosus

Sixalix atropurpurea

Arisarum vulgare

Convolvulus althaeoides

Dactylis glomerata

Allium subhirsutum

Molinio-Arrhenatheretea s.l.

Festuca rubra

Anthoxanthum odoratum

Taraxacum fulvum

Cynosurus cristatus

Bellis perennis

Rhinanthus minor

Trifolium incarnatum

Trifolium repens

Trifolium striatum

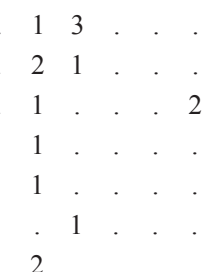


Column number $\begin{array}{llllllllllllllllllllllllll}1 & 2 & 3 & 4 & 5 & 6 & 7 & 8 & 9 & 10 & 11 & 12 & 13 & 14 & 15 & 16 & 17 & 18 & 19 & 20 & 21 & 22 & 23 & 24 & 25 & 26\end{array}$

Galium verum

Viola eugeniae

Luzula campestris

Agrostis capillaris

Carex flacca

Colchicum lusitanum

Lolium perenne

Lathyrus pratensis

Poa pratensis

Rumex acetosella

Trifolium nigrescens

Trifolium pratense

Arrhenatherum elatior

Cruciata laevipes

Taraxacum officinale

Tragopogon pratensis

Holcus lanatus

Phleum pratense

Poa compressa

Tragopogon porrifolius

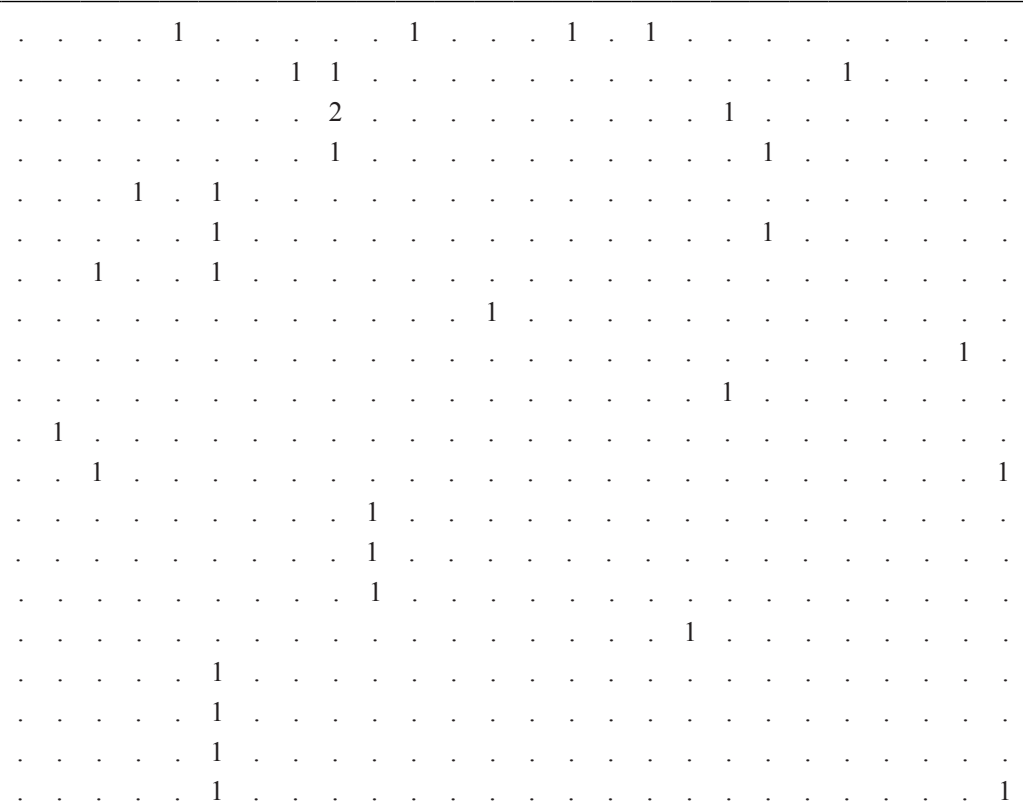

Tuberarietea / Sedo-Scleranthetea

Sedum rupestre

Sedum acre

Trifolium scabrum

Arenaria serpyllifolia

Sedum album

Catapodium rigidum

Coronilla scorpioides

Trifolium stellatum

Bombycilaena erecta

Alyssum alyssoides

Sherardia arvensis

Euphorbia exigua

Acinos arvensis

Saxifraga tridactylites

Hypochaeris achyrophorus

Linum trigynum

Trachynia distachya

Vulpia ciliata

Cerastium glutinosum

Linum strictum

Vulpia myuros

Aira caryophyllea

Anagallis arvensis

Erophila verna

Hornungia petraea

Trifolium arvense

Xeranthemum inapertum

$\begin{array}{llllllllllllllllllllllll}4 & 3 & 3 & 4 & 2 & 2 & . & 5 & 5 & . & . & 3 & . & 3 & 4 & 2 & . & . & 4 & 4 & 2 & 2 & 2 \\ . & . & . & 2 & 1 & . & . & 2 & 2 & 1 & 1 & 3 & 1 & 3 & 5 & & 4 & & 1 & 2 & 5 & 1 & 1\end{array}$

Crupina crupinastrum

Trifolium angustifolium

Althaea hirsuta

Arenaria leptoclados

Sedum reflexum

Blackstonia perfoliata

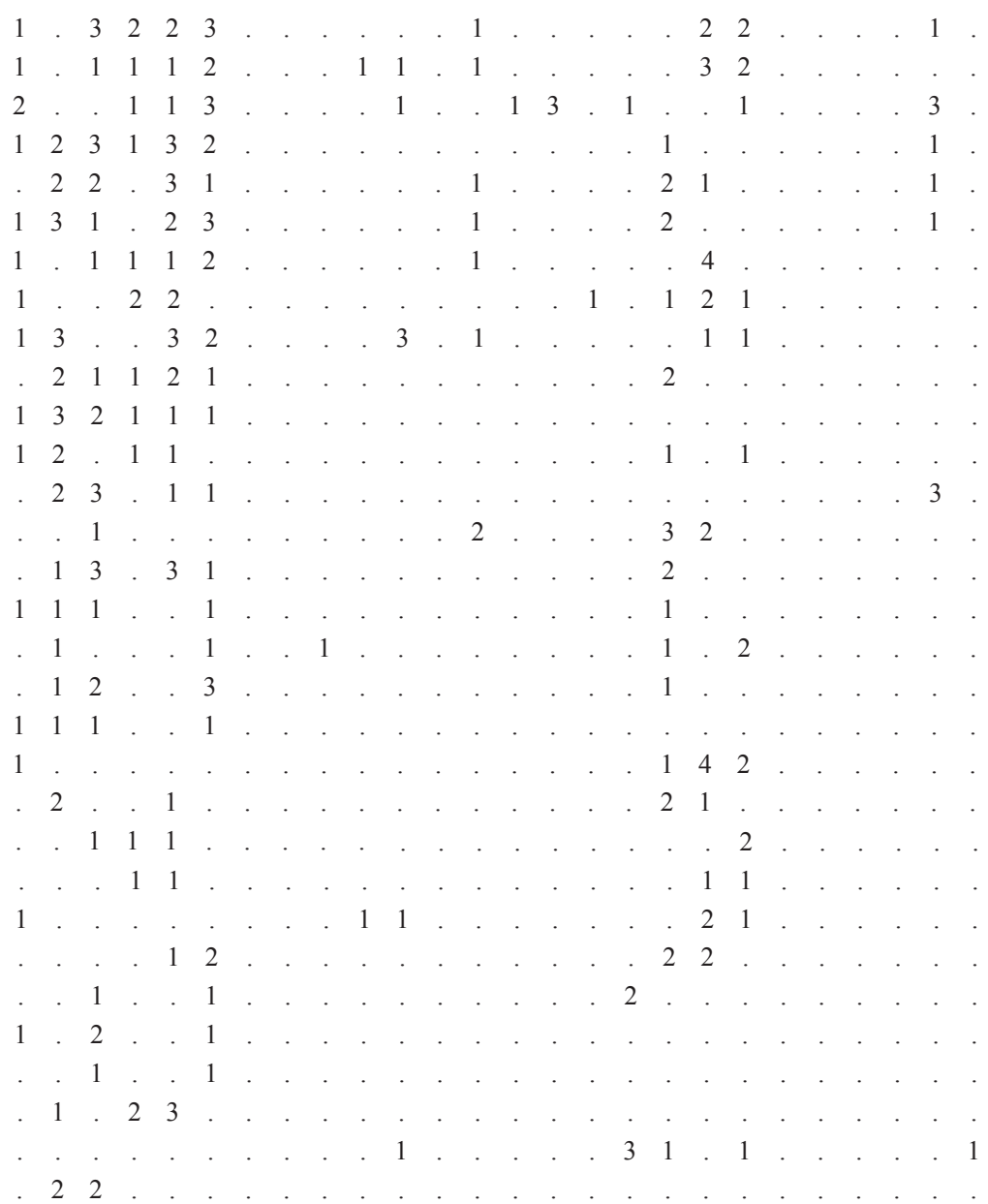


Column number

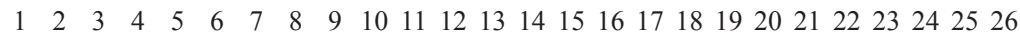

Hippocrepis biflora

Medicago rigidula

Scorpiurus muricatus

Sonchus tenerrimus

Cerastium brachypetalum

Filago pyramidata

Minuartia mediterranea

Sedum amplexicaule

Filago vulgaris

Plantago lagopus

Asterolinon linum-stellatum

Bromus madritensis

Euphorbia falcata

Euphorbia peplus

Lotus ornithopodioides

Melilotus sulcata

Urospermum picroides

Galium parisiense

Linaria simplex

Silene conica

Trifolium lappaceum

Tuberaria guttata

Onobrychis caput-galli

Other species

Hypericum perforatum

Lactuca perennis

Carex halleriana

Spartium junceum

Geranium columbinum

Astragalus sempervirens

Echium vulgare

Poa bulbosa

Silene vulgaris

Digitalis lutea

Quercus pubescens

Allium vineale

Euphorbia helioscopia

Odontites lutea

Picris hieracioides

Romulea bulbocodium

Veronica arvensis

Ornithogalum comosum

Cuscuta epithymum

Gastridium ventricosum

Orobanche minor

Scrophularia canina

Medicago prostrata

Carlina vulgaris

Asparagus acutifolius

Quercus ilex

Rhamnus saxatilis

Asphodelus albus

Centaurea solstitialis

Ceterach officinarum

Crepis sancta 
Column number

Galactites elegans

Lathyrus sylvestris

Leontodon villarsii

Minuartia hybrida

Orobanche purpurea

Orobanche teucrii

Salvia verbenaca

Saxifraga bulbifera

Scilla autumnalis

Sedum dasyphyllum

Silene italica

Stachys officinalis

Thalictrum minus

Tordylium apulum

Verbascum longifolium

Carduus micropterus

Dasypyrum villosum

Ophrys bertolonii

Phillyrea latifolia

Acer opalus obtusatum

Crataegus monogyna

Fraxinus ornus

Ostrya carpinifolia

Rosa canina

Rosa spinosissima

Sesleria autumnalis

Helianthemum oelandicum

Astragalus sirinicus

Buxus sempervirens

Calamintha nepeta

Centaurea calcitrapa

Echium plantagineum

Geranium dissectum

Geranium rotundifolium

Geranium sanguineum

Hieracium sabinum

Leontodon rosani

Linaria purpurea

Nigella damascena

Onopordum acanthium

Orlaya daucoides

Pallenis spinosa

Pistacia terebinthus

Ranunculus gramineus

Scabiosa gramuntia

Sempervivum tectorum

Carthamus lanatus

Muscari comosum

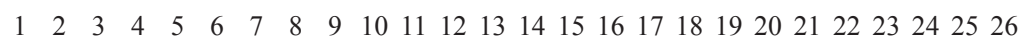
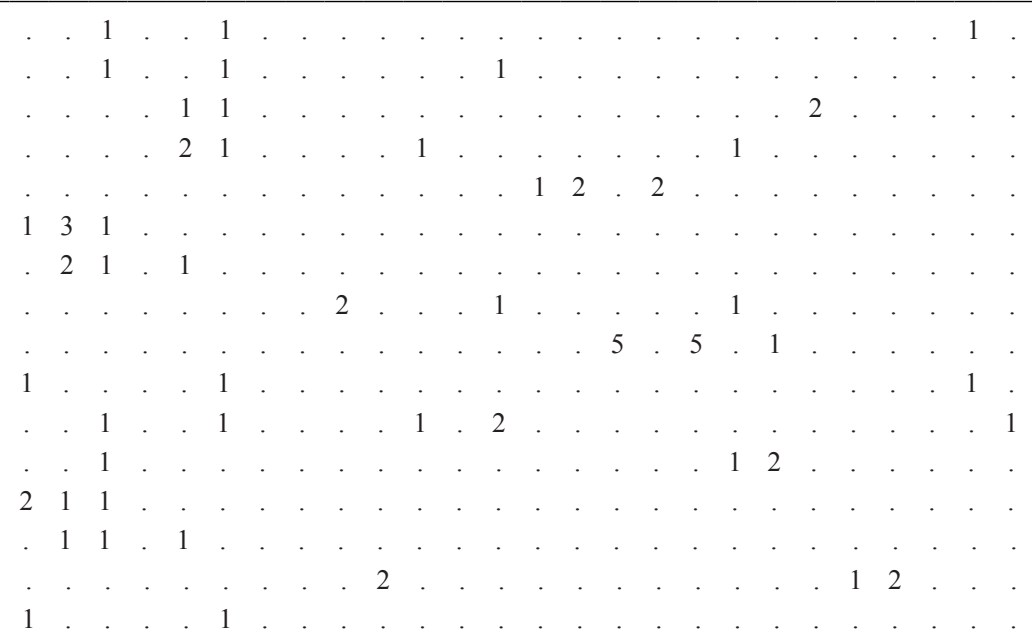

1

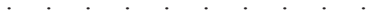

$$
1
$$$$
11
$$$$
41
$$$$
\text { . } 22
$$$$
\text { . } 31
$$$$
\text { . } 11
$$$$
2.1
$$$$
\text { 1 } 1
$$$$
\text { . } .
$$$$
\cdot \cdot \cdot \cdot \cdot 1
$$$$
\text { . . } 11 \text {. }
$$$$
\text { . } 21
$$$$
\text { . } 1
$$$$
\text { . . } 11
$$$$
\text { . } 1 . .1
$$$$
\text { . } 1 . .1
$$$$
11
$$$$
\text { . . } 11
$$$$
\cdot \cdot \cdot \cdot \cdot
$$$$
\text { . } 1
$$$$
21
$$$$
1.1
$$$$
\text { . } 1
$$$$
\text { . } 11
$$$$
\text { . . . . } 44
$$

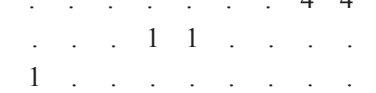$$
2
$$

Legend of the abbreviations in the synoptic table:

$\mathbf{A B}=$ Artemisio-Brometalia $\mathbf{P B c}=$ char. species of Phleo-Bromenion; $\mathbf{P B t}=$ transgr. species in Phleo-Bromenion $; \mathbf{P B i}=$ insgr. species in Phleo-Bromenion; $\mathbf{C B c}=$ char. species of Cytiso-Bromion; $\mathbf{C B r c}=$ regional char. species of Cytiso-Bromion; $\mathbf{C B p c}=$ partial char. species of Cytiso-Bromion; $\mathbf{C B t}=$ transgr. species in Cytiso-Bromion; $\mathbf{C B i}=$ insgr. species in Cytiso-Bromion; $\mathbf{S c}=$ char. species of Sideritidenion italicae $; \mathbf{S r c}=$ regional char. species of Sideritidenion $; \mathbf{S p c}=$ partial char. species of Sideritidenion; $\mathbf{S t}=$ transgr. species in Sideritidenion; $\mathbf{S} \mathbf{i}=$ insgr. species in Sideritidenion . 